\title{
Investigation-Derived Waste
}

\section{Management Plan}

Westinghouse Savannah River Company Savannah River Site Aiken, South Carolina 29808

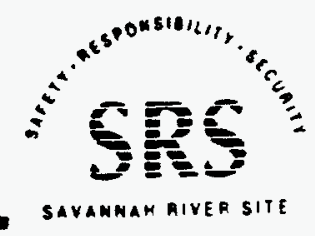

PREPARED FOR THE U.S. DEPARTMENT OF ENERGY UNDER CONTRACT DE-AC09.89-SR18035

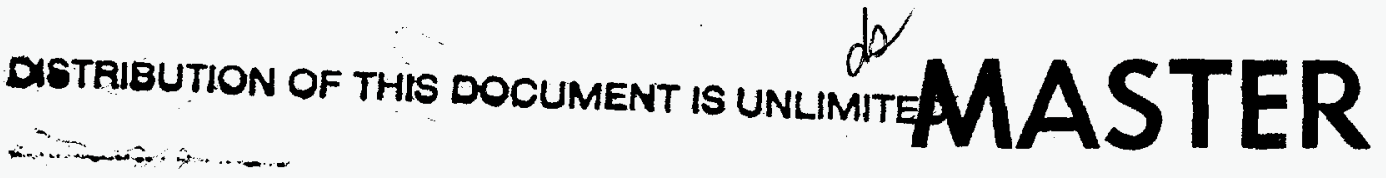


This page is intentionally left blank. 


\section{DISCLAIMER}

This report was prepared as an account of work sponsored by an agency of the United States Government. Neither the United States Government nor any agency thereof, nor any of their employees, make any warranty, express or implied, or assumes any legal liability or responsibility for the accuracy, completeness, or usefulness of any information, apparatus, product, or process disclosed, or represents that its use would not infringe privately owned rights. Reference herein to any specific commercial product, process, or service by trade name, trademark, manufacturer, or otherwise does not necessarily constitute or imply its endorsement, recommendation, or favoring by the United States Government or any agency thereof. The views and opinions of authors expressed herein do not necessarily state or reflect those of the United States Government or any agency thereof. 


\section{DISCLAIMER}

Portions of this document may be illegible in electronic image products. Images are produced from the best available original document. 


\section{TABLE OF CONTENTS}

EXECUTIVE SUMMARY

ES-1

1.0 INTRODUCTION 1

2.0 IDW MANAGEMENT 3

2.1 DW Management: General Practice Guidelines 3

2.2 Management of IDW from Non-Listed Sources 10

2.2.1 Aqueous IDW from Non-Listed Sources 13

2.2.2 Non-Aqueous IDW from Non-Listed Sources 14

2.3 Management of IDW from Listed Sources 18

2.3.1 Aqueous IDW from Listed Sources 18

2.3.2 Non-Aqueous IDW from Listed Sources 20

$\begin{array}{ll}\text { 3.0 IDW MINIMIZATION } & 21\end{array}$

4.0 IDW IMPLEMENTATION SCHEDULE 23

4.1 Management Implementation for IDW from Non-Listed Sources 23

4.2. Management Implementation for IDW from Listed Sources 23

References

Appendices 
This page is intentionally left blank. 


\section{List of Figures}

Figure 2-1 Investigation-Derived Waste Management Plan

Figure 2-2

IDW Management Unit at Area of Contamination

Figure 2-3

Aqueous IDW Management From Non-Listed Sources

Non-Aqueous IDW Management From Non-Listed Sources

Figure 2-4

Non-Aqueous IDW Management From
IDW Management From Listed Sources

Figure 2-5

\section{List of Tables}

Table 2-1 Typical IDW Containerization Method

Table 2-2 Annual Purge Water Summary

\section{List of Appendices}

Appendix A Health Based Levels for Aqueous IDW

Appendix B Health Based Levels for Non-Aqueous IDW

Appendix C IDW Implementation Schedule

\section{List of Acronyms}

$\begin{array}{ll}\text { AOC } & \text { Area Of Contamination } \\ \text { CERCLA } & \text { Comprehensive Environmental Response, Compensation, and Liability Act } \\ \text { DAF } & \text { Dilution and Attenuation Factor } \\ \text { EPA } & \text { Environmental Protection Agency } \\ \text { F/H ETF } & \text { F/H-Area Effluent Treatment Facility } \\ \text { FIP } & \text { Field Investigation Plan } \\ \text { HBL } & \text { Health-Based Levels } \\ \text { HW } & \text { Hazardous Waste } \\ \text { IDW } & \text { Investigation-Derived Waste } \\ \text { IWT } & \text { Industrial Wastewater Treatment } \\ \text { MCL } & \text { Maximum Contaminant Levels } \\ \text { MU } & \text { Management Unit } \\ \text { MWMF } & \text { Mixed Waste Management Facility } \\ \text { PPE } & \text { Personal Protection Equipment } \\ \text { RCRA } & \text { Resource Conservation and Recovery Act } \\ \text { SDWA } & \text { Safe Drinking Water Act } \\ \text { SCDHEC } & \text { South Carolina Deparment of Health and Environmental Control } \\ \text { SRS } & \text { Savannah River Site } \\ \text { TCLP } & \text { Toxicity Characteristic Leaching Procedure } \\ \text { TSS } & \text { Total Suspended Solids } \\ \text { VOC } & \text { Volatile Organic Compounds } \\ \text { WSRC } & \text { Westinghouse Savannah River Company } \\ & \\ \text { List of Abbreviations and Units } \\ \text { CuFt } & \text { Cubic Feet } \\ \text { mg/ } & \text { milligrams per liter } \\ \text { pCi/g } & \text { pico Curie per gram } \\ \text { PCiml } & \text { pico Curie per milliliter } \\ \text { mg/kg } & \text { milligram per kilogram }\end{array}$


This page is intentionally left blank. 


\section{EXECUTIVE SUMMARY}

This document describes the Savannah River Site (SRS) plan for the management of investigationderived waste (IDW) generated during investigations performed under the regulatory authority of the Resource Conservation and Recovery Act (RCRA), as amended, and the Comprehensive Environmental Response, Compensation, and Liability Act (CERCLA), as amended. IDW includes potentially contaminated environmental media such as monitoring well purge water, well pumping test and development water, drilling mud, and soil drill cuttings. IDW also includes decontamination and rinse waters as wel! as equipment and personal protective equipment that have not been decontaminated. The SRS IDI: management strategy is to minimize the quantity of DW generated while cost-effectively managing the IDW which must be generated.

Two management programs are encompassed within this plan: IDW derived from contact with non-listed hazardous wastes (non-listed IDW) and that derived from contact with listed wastes (listed IDW).

- Non-listed IDW will be managed utilizing appropriate practices for concentrations not exceeding ten times (10x) the Health-Based Levels (HBLs) presented in Appendix A (Aqueous IDW), or not exceeding the HBLs in Appendix B (Non-Aqueous IDW) and through implementation of the activities identified in this IDW Management Plan for concentrations exceeding 10x HBLs in Appendix A or exceeding the HBLs in Appendix B.

Non-listed IDW will be managed as hazardous waste if it is characteristically hazardous.

The choice of 10 as a multiplier for determining the action levels for non-listed aqueous IDW is based on employing a prudent approach to the management of IDW which is protective of human health and the environment. This management approach is discussed further in Section 2.2.

- Listed IDW containing constituents exceeding HBLs listed in Appendix A (aqueous IDW) or Appendix B (non-aqueous $\mathrm{DWW}$ ) will be managed as a hazardous waste, consistent with EPA's Contained-In Policy.

These programs are consistent with EPA guidance for management of IDW and are protective of human health and the environment.

SRS has already taken actions to develop the necessary treatment capacities for the different categories of IDW. The schedules contained in Appendix C identify the major activities completed to date. The schedules are considered integral to the full implementation of the IDW Management Plan. In addition, SRS is pursuing innovative technologies and practices as described in this Plan to reduce the volume of IDW that is generated. This approach will reduce the potential for worker exposure and will minimize material handling activities. These innovative technologies and practices will be introduced to the EPA and South Carolina Department of Health and Environmental Control (SCDHEC) for implementation at SRS. 
WSRC-RP-94-1227

Revision 2

This page is intentionally left blank.

ES- 1 


\subsection{INTRODUCTION}

SRS has implemented a comprehensive environmental program to maintain compliance with environmental regulations and mitigate impacts to the environment. One element of the environmental program is the investigation of inactive waste units. Environmental investigations typically employ activities such as drilling and excavating, which produce Investigation-Derived Waste (IDW). IDW may include purge water, soil cuttings, drilling fluids, well pumping test and development water, decontamination solutions, contaminated equipment, and personal protection equipment (PPE). In cases where investigations confirm the presence of contamination and the IDW contains waste constituents in concentrations high enough to be of environmental or health concern, special management procedures are warranted.

This IDW Management Plan describes specific SRS initiatives for IDW management. The goal is the development of a plan for prudent management of IDW from environmental investigations that is protective of human health and the environment. 
WSRC-RP-94-1227

Revision 2

This page is intentionally left blank.

2 


\subsection{IDW MANAGEMENT}

IDW management at SRS is divided into two programs: management of IDW generated from nonlisted sources and management of IDW generated from listed sources. Within these two programs, IDW is further defined as either aqueous IDW (purge water or other aqueous solutions resulting from the groundwater monitoring and sampling programs) or non-aqueous (solid phase) IDW resulting from waste unit investigation activities. Management levels for the various IDW categories are presented in Appendices A and B of this Plan. An overview of this IDW Management Plan, which considers IDW generated from both inside the area of contamination (AOC) and outside the AOC is illustrated in Figure 2-1. The schedules contained in Appendix C are integral to the full implementation of the IDW Management Plan.

\subsection{IDW Management: General Practice Guidelines}

The SRS guidance for managing IDW is related to the type of waste being generated during environmental investigations and the location of the work site, i.e., inside the AOC or outside the AOC. The AOC is defined as the area inside the limits of known contamination. The limits are defined after research of documentation indicate buried waste, surface spills, waste releases, etc., or from direct evidence of surface waste or contamination at the work area. The AOC boundaries are approximated by orange ball markers posted at the corners of the waste units. In other cases, the AOC boundary is defined by the approved closure plan or other legally binding agreements for an operating, closing, or closed Hazardous Waste Management Facility.

The following implementation guidance is appropriate whether the source of IDW is listed or nonlisted:

IDW Generated Inside the AOC:

- SRS will place non-aqueous IDW into management units inside the AOC. The management unit will be constructed so that the bottom of the management unit is no closer than ten (10) feet from the known water table as illustrated in Figure 2-2. The IDW will remain in the management unit and will be dispositioned consistent with the final remedial actions for the waste unit.

IDW Generated Outside the AOC:

Consistent with EPA guidance (Document \#9345.3-03FS, "Guide to Management of Investigation-Derived Wastes"), it will not be presumed that IDW solids resulting from core borings or well drilling operations outside the $A O C$ are hazardous unless positive evidence (records or other documentation) indicate otherwise. In all cases, best professional judgment and available information will be utilized in conjunction with the following guidance to determine the appropriate management actions for $\mathrm{DW}$ which is generated outside the AOC.

- If it is known from document research that the drilling site is located over a contaminated groundwater plume (or hydrologically downgradient of a waste unit), then IDW resulting from penetration into the contaminated zone will be containerized at the work site and a representative sample collected for analysis. SRS will use laboratory analyses to determine whether the IDW is managed as hazardous until field screening methodologies are demonstrated and determined to be effective. Upon receipt of laboratory analyses. IDW will be dispositioned in accordance with the appropriate actions as delineated in Section 2.2 or Section 2.3. 


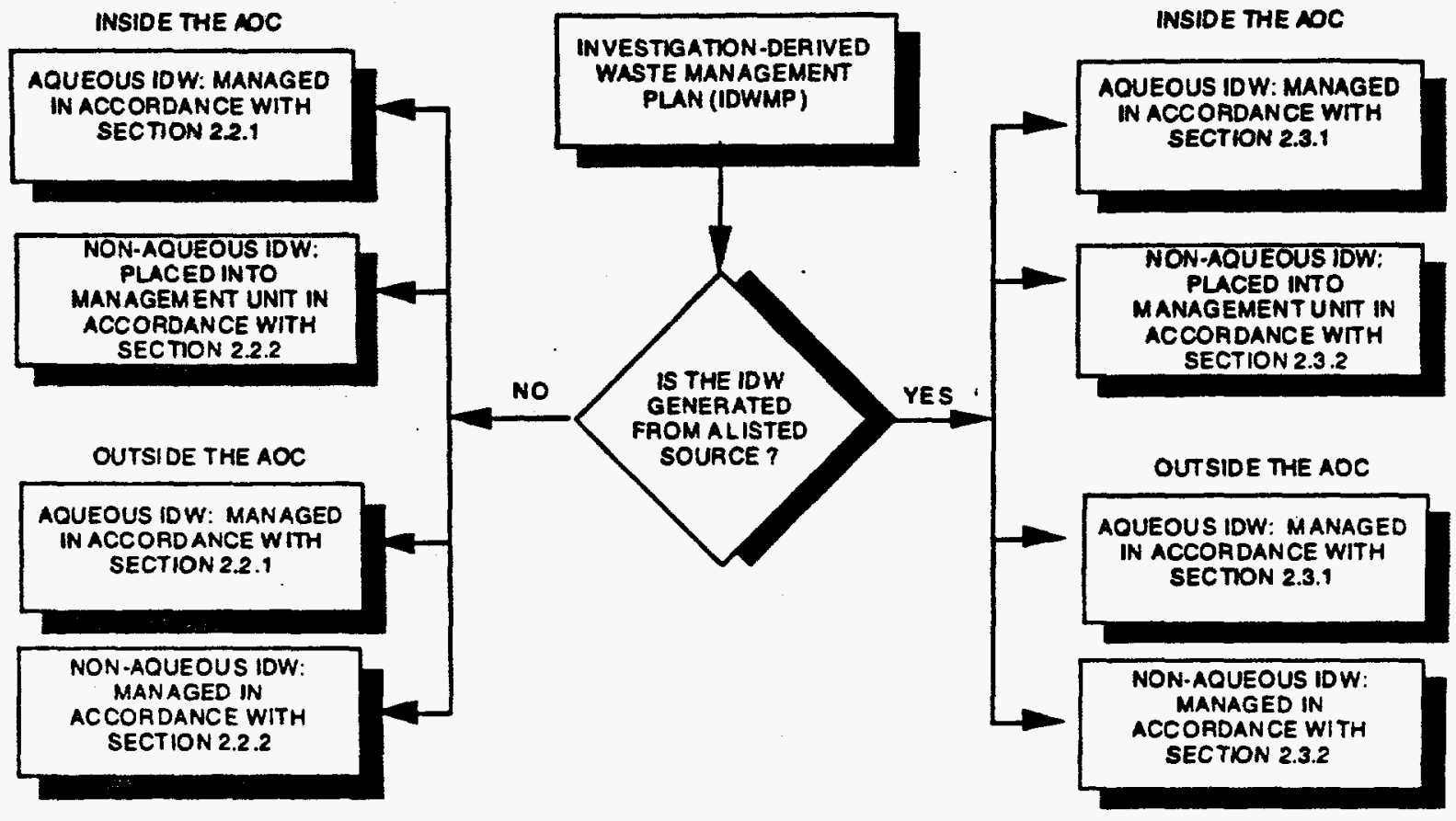

Figure 2-1. Investigation-Derived Waste Management Plan 


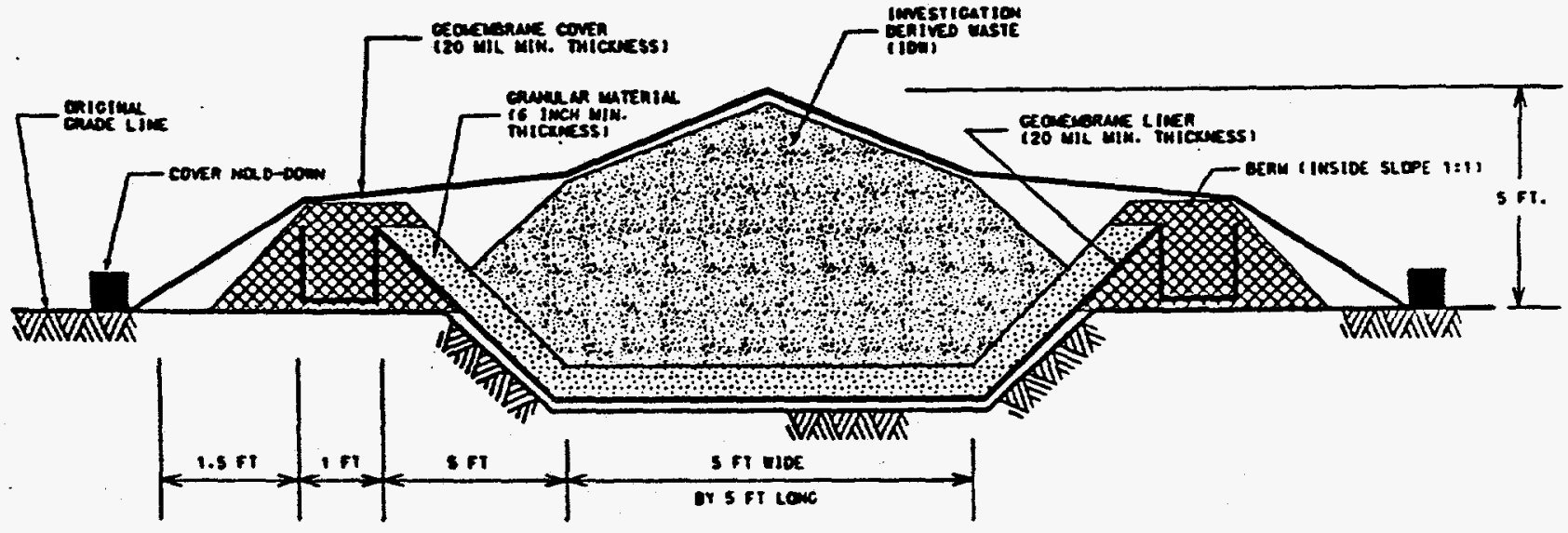

moles:

1. Assuprion - oesich is rog 3 ELLS TITH A

2. Thu acerss Rup not smow.

3. cui value couns rith vouk.

4. sxetcon ts not onden to sener.

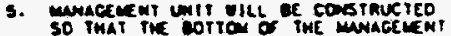

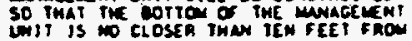
int? is to cios

Figure 2-2. IDW Management Unit at Area of Contamination (AOC) (Typical) 
If it is known from document research that positive evidence does not exist that hazardous constituents were disposed in the vicinity of the work site and the work is being conducted at a location where there are no upgradient waste units and no contamination is expected, the IDW will be managed using appropriate practices such as land application.

Example: Assume a core boring operation is needed in the greater A/M Area, which is known to have underlying groundwater with contamination from F001 listed constituents. At this example location outside the AOC, records indicate groundwater contamination is at a depth of 100 feet. Also, assume the boring will be to a depth of 80 feet. No other records indicate contamination in this area within the 80 foot depth. The drill cuttings from this operation would be considered clean and placed in the immediate vicinity using appropriate practices such as land application.

If the core boring operation includes a plan modification to drill to a depth below 100 feet, into the contaminated groundwater, then the drill cuttings from the contaminated zone would be containerized and analysis would be performed. The containerized soils would be labeled as hazardous and managed appropriately. If the analytical results indicate concentrations of hazardous constituents are below applicable management levels (see Appendix B), the drill cuttings would be disposed by using appropriate practices such as land application. If the analytical results indicate concentrations of hazardous constituents are above the applicable management levels (see Appendix B), the container would be managed as hazardous waste. The 90-day staging period would start when waste is first placed in drums for quantities greater than 55 gallons. This IDW would be labeled as a hazardous waste, staged and sent to a treatment/storage/disposal facility within the 90-day time frame.

Containerization methods of suspect IDW will be dependent upon the type and volume of material, and will be specifically detailed in the unit-specific work plan. A unit-specific table will be developed and included in the unit work plan as a guide to show what containers are to be used for various media and volumes. An example table is presented in Table 2-1.

\section{Table 2-1 - Typical IDW Containerization Methods}

\begin{tabular}{|c|c|c|c|}
\hline MEDIA TYPE & CONTAINER TYPE & STAGING METHOD & CONTAINER CAPACITY \\
\hline Soils/solids. PPE & $\begin{array}{c}\text { Skid Pan } \\
\text { Drum }\end{array}$ & Adjacent to Work Site & $\begin{array}{c}2.100 \text { Gallons } / 280 \text { CuFt } \\
55 \text { Gallons } / 7.65 \text { CuFt }\end{array}$ \\
\hline $\begin{array}{c}\text { Water/Slurries, } \\
\text { Drilling Fluids }\end{array}$ & $\begin{array}{c}\text { Adjacent to Work Site, } \\
\text { on pallet with secondary } \\
\text { containment }\end{array}$ & 55 Gallons $/ 7.65$ CuFt \\
\hline
\end{tabular}

During specific work plan development, a review of this table would be conducted to determine the appropriate method of containerization and staging based on media. estimated volume, and location of the work (inside or outside of the $\mathrm{AOC}$ ). For large volumes of homogeneously contaminated soils, a skid pan may provide better containerization and management than 55 -gallon drums. 
Two procedures will be developed, or the existing procedures will be revised, and incorporated within the Westinghouse Savannah River Company (WSRC) 3Q-Environmental Compliance Manual. Copies of the "draft" procedures will be provided within three (3) months of finalization of the IDW Management Plan to EPA and SCDHEC addressing the following issues:

(1) IDW Staging Requirements: This procedure will encompass the appropriate requirements for establishing an DW staging area, including posting requirements, maintenance and operation of the staging area, and closure of the staging area. The procedure will also identify the appropriate references for guidance depending on the outcome of the laboratory analyses.

(2) IDW Surface Water Runoff Control: This procedure will address control of surface water runoff toward local wetlands or surface water drainage ditches. The current SRS monitoring well purging practice is to employ discharge hoses to minimize erosion and to control flow direction.

The procedure will document the appropriate discharge methods during monitoring well purging operations and will include directing the purge water away from ecologically sensitive areas.

Open boreholes resulting from drilling activities will be abandoned by filling with cement grout from the bottom of the hole to the ground surface in accordance with approved WSRC procedures.

\section{Purge Water from New Wells}

Purge water from new monitoring well installations will be managed in accordance with the following guidance, as applicable:

- If a new well is both downgradient of a waste unit and upgradient of a well where purge water requires containerization, then purge water from the new well will be containerized until analytical results justify removal of the new well from the purge water containerization list.

- If a new well is known to be or is potentially downgradient (accounting for possible radial flow from the source area) of a waste unit and upgradient of wells where purge water does - not require containerization, but one well monitoring this unit does require containerization, then purge water from the new well will be containerized until analytical results justify removal of the new well from the purge water containerization list.

- If no downgradient or upgradient wells monitoring the waste unit are contaminated, then purge water from the new well will not be containerized unless subsequent analytical results justify addition of the new well to the purge water containerization list.

- If the new well is being installed at a waste unit without wells monitoring the target aquifer of the new well, then purge water from the new well will be containerized until analytical results justify removal of the new well from the purge water containerization list.

- In all other cases, if the new well is being installed for background or other evaluation purposes where no waste unit exists, then purge water from the new well will not be containerized until analytical results justify addition of the new well to the purge water containerization list. 


\section{Radionuclides in Non-agueous IDW}

Fay and Pickett (1987) have defined background activity levels produced by naturally-occurring radionuclides from U-238 and Th-232 decay chains and from $\mathrm{K}-40$ in shallow surface soils at the Savannah River Site. These mean values for background are: 9.70 total pCi/gram from the U-238 series, 9.32 total $\mathrm{pCi} / \mathrm{gram}$ from the Th-232 series, and $0.537 \mathrm{pCi} / \mathrm{gram}$ from K-40. Fay and Pickett also established a background value of $0.145 \mathrm{pCi} /$ gram for fission product Cs-137, which has resulted from atmospheric fallout.

Holcomb (1995) has described the impact of the magnitude of the background activity levels on residential preliminary remediation goals (PRGs) established from soil ingestion and exposure and based on the 1E-06 cancer risk. When compared to Fay and Pickett's mean activity levels, the activity of each of the following naturally-occurring radionuclides exceeds the 1E-06 based PRGs (ingestion, exposure): $\mathrm{K}-40, \mathrm{~Pa}-234, \mathrm{~Pb}-214, \mathrm{Bi}-214, \mathrm{Ra}-228, \mathrm{Ac}-228, \mathrm{~Pb}-212, \mathrm{Bi}-212$, and $\mathrm{Tl}-$ 208. It is most important to note that the background activity of Tl-208, or that from Ra-228 plus daughters, even exceeds the IE-04 risk based industrial PRG for soil.

The sources for these comparably high levels are from the minerals gorceixite and monazite (Thayer, 1983; Looney, 1990). It is quite possible that naturally-occurring activities in soils interlayered with thin seams or nodules of these minerals could easily exceed the background levels of Fay and Pickett.

Current protocol describes establishing background levels as part of the characterization of specific waste sites at SRS. For soils, the process includes activity indicator screening by gross alpha and gross non-volatile beta-gamma counting. Soils exceeding trigger levels of $20 \mathrm{pCi}$ alpha/gram and/or $50 \mathrm{pCi}$ non-volatile beta-gamma/gram are further characterized for individual radionuclide contributors. These trigger levels have permitted quantifying fractional or greater $\mathrm{pCi} / \mathrm{gram}$ levels of naturally-occurring radionuclides while establishing the presence of less-than-detectable levels (< 1 pCi/gram) of fission and activation products (Holcomb, 1995).

These screening trigger levels were set in a cooperative effort between personnel from the Analytical Development Division at the Savannah River Technology Center (SRTC), and from the Environmental Restoration Department. The trigger levels take into consideration the Fay and Pickett background levels, instrument limits of detection combined with practical counting times, and data requirements tempered by the need to minimize analytical costs.

The following protocol will be used for the radionuclide quantification of soil generated as IDW at the individual sites. If nonaqueous IDW is generated outside an $A O C$ and/or evidence suggests that no potential radiological contaminants of concern are above SRS background concentrations at the operable unit, the soil screening trigger levels of $20 \mathrm{pCi}$ alpha/gram and/or $50 \mathrm{pCi}$ non-volatile beta-gamma/gram are adequate. If a work site under investigation (e.g., operable unit, AOC, environmental media impacted by operable unit releases) has a potential for radiological contamination, the unit specific work plan will identify the potential radiological contaminants of concem and the analytical approach. IDW with potential radiological contaminants of concern exceeding the IDW screening levels in Appendix B shall be managed in accordance with the IDW Plan.

\section{Tritum Contaminated Media}

The primary reason for altemate management strategies for tritiated wastewater is the lack of any practical treatment technology. Tritium's chemical reaction properties are indistinguishable from 
those of hydrogen, and its physical-chemical effects on properties such as viscosity and boiling point are so small that existing separation technology cannot remove enough tritium from any given waste stream for the treated effluent to meet drinking water standards, which are the most conservative protectors of human health. Thus, an alternative strategy is necessary to ensure protection of human health and the environment.

Mixing with nontritiated water and radioactive decay are the only two practicable means of reducing dose from any given volume of tritiated wastewater. Enhancing evapotranspiration and soil infiltration in the immediate vicinity of the source of tritiated groundwater combines these two dose-reduction methods in a prudent and cost-effective way that is also consistent with the As Low As Reasonably Achievable (ALARA) method of controlling radioactive releases. Note, however, that SRS IDW management requirements are triggered by the most restrictive requirement applicable to any constituent present in the material; thus, if the contaminated medium contained both tritium and an organic compound, and the organic levels exceeded the applicable action level, management would be required. The only case in which tritiated media do not require management is if they meet all the following requirements:

- No other constituent exceeds applicable action levels.

- Tritium activity levels are below safe exposure levels.

Because worker exposure to tritiated wastewater for a 40-hour work week is permissible at levels of $4.0 \mathrm{E} 05 \mathrm{pCi} / \mathrm{ml}$, a reasonable conservative estimate for IDW management limits applicable to SRS workers would be $8.0 \mathrm{E} 05 \mathrm{pCi} / \mathrm{ml}$ (since samplers are potentially exposed no more than $50 \%$ of the time). Note that protective measures to prevent unauthorized visitors to SRS prevent acute exposure to nonworkers.

Neither future nor chronic exposure is possible from tritiated wastewater releases, due to tritium's behavior in the environment:

- no measurable bioaccumulation in humans (half-life of 7-10 days)

- no measurable bioaccumulation in ecological receptors

- no measurable accumulation in nonliving environmental receptors

- identical transportation through the hydrologic cycle, compared to water

- relatively shor half-life, 12.7 years

Tritiated IDW releases may partition into air; transpiration; soil moisture; surface runoff; and groundwater. Sampling procedures preclude surface runoff for all IDW. Of the remaining media receptors, dose impacts for evaporated and transpired tritium are identical. Similarly, soil moisture and groundwater (during groundwater transport) have identical dose impacts. Finally, in case groundwater reaches surface water discharge before decay, a surface water dose impact must be considered. Of these three, groundwater releases have the least impact (zero dose), followed by air releases and reaching maximum dose (in terms of both maximum individual and population doses) in surface water releases. Because tritium is not treated by wastewater treatment facilities, and all such facilities at SRS discharge into Savannah River contributing streams, treatment of tritiated IDW will result in some minor increase in dose contribution. Present practices result in $>30 \%$ loss by evapotranspiration as well as entrainment for significant lengths of time (in terms of tritium halflives) as soil moisture and groundwater.

For further detailed analysis of groundwater flow patterns in the vicinity of SRS reactors see FINAL REPORT: Numerical Simulation of Groundwater Flow and Contaminant Transport at the K, L. and P Areas of the Savannah River Site, Aiken, South Carolina, Camp Dresser \& McKee Inc., WSRC-RP-89-1198. For general discussions of the environmental impact of discharging 
tritiated wastewaters at SRS, see Environmental Information Document: Reactor Seepage Basins (U), WSRC-RP-90-1299.

The greatest potential for exposure of tritium to both the biosphere and human health results from discharge into surface streams that eventually reach the Savannah River. Releases strictly to the air result in a more limited exposure potential. Releases to the ground, which include at least a small component of air release due to evapotranspiration, result in the minimum exposure potential to human health and the environment. In all three scenarios, the small tritium inventory and relatively low activity levels of tritiated purge water result in an extremely small dose. Therefore, any purge water containing only tritium will be discharged to the ground in the vicinity of the well. This management option results in the least impact to human health and the environment. Note that a conservative tritium inventory of all SRS monitoring well purge water, assuming 4 samples/year, is below 5 Curies/year. Rinse and decontamination water combined with well development water will contain less tritium than purge water. Thus, tritiated wastewaters from all IDW will not exceed 10 Curies/year. For comparison, the average throughput of the F/H Effluent Treatment Facility (F/H ETF) is roughly 1000 Curies/year. The existing throughput of tritium through the F/H ETF does not have a measurable impact on the biosphere and little impact on human health. Drinking water supplies originating in downstream Savannah River water are not compromised by SRS discharges of tritiated water. The concentration of tritium in the Savannah River, just downstream from the Site, due to SRS operations is 0.17 of the limit set by the Drinking Water Standard (DWS) of $20,000 \mathrm{pCi} /$. The concentration at downstream water supplies is about 0.13 of the DWS.

Purge water containing tritium and another constituent (for non-listed, exceeding 10x HBLs in Appendix A; for listed, exceeding the HBLs in Appendix A), will be managed according to the protocol for the other constituent.

\section{Personal Protection Equipment (PPE)}

Decontaminated PPE will be considered below HBL criteria and, therefore, will either be laundered and reused or routinely disposed. Decontamination equipment will either be reused, decontaminated and routinely disposed, or managed within the AOC until dispositioned during final remedial actions for the waste site. PPE contaminated by tritium alone will be decontaminated once completely dry. Other equipment that cannot be decontaminated will be segregated from cleaned materials and evaluated for appropriate disposal.

\subsection{Management of IDW From Non-Listed Sources}

The SRS IDW Management Strategy is to minimize the quantity of IDW generated while cost effectively managing the IDW which must be generated. The apparent inconsistency of managing listed aqueous IDW at action levels lower than the non-listed aqueous IDW is justified based on the volume difference, and thus cost difference, requiring management. This prudent approach is protective of human health and the environment and is consistent with the Contained-In Policy. Thus, the SRS IDW Management Plan includes two segments for the management of aqueous IDW: one segment for listed aqueous IDW in accordance with the action levels specified in Appendix $A$, and the second segment for nonlisted aqueous IDW to action levels derived by applying a Dilution and Attenuation Factor (DAF) to the Appendix A levels.

A minimum DAF of 10 was chosen as a default for two main reasons: first the DAF of 10 is based on extensive modeling and field studies by EPA (see pages 13-14 in EPA/540/R-94/101. Soil Screening Guidance, 12/94; and EPA/540R-94/102. Technical Background Document for Soil 
Screening Guidance, 12/94). A DAF of 10 accounts for the effects of transport from materials released into the environment as they interact with the biosphere, soil, air, soil moisture, and groundwater. Higher DAF values are appropriate for many constituents other than tritium, which warrants a high DAF due to both site-specific conditions and physical properties.

Further technical justification is provided when considering that EPA established, by extensive analysis and validation, the TCLP levels for metals and organics in the Toxicity Characteristics Revisions final rule (the TCLP rule) in 55 FR 11798 (3/29/90). EPA technically justified using MCLs as a starting point for developing regulatory levels, stating: "EPA maintains that the MCLs, when they exist, are the most appropriate health criteria to use as the starting point for developing regulatory levels (55 FR 11813)".

Based upon the application of the EPA CML model as applied to landfills, EPA also technically justified a Dilution and Attenuation Factor (DAF) of 100 for all TCLP (characteristic) constituents. SRS recognizes that the DAF of 100 is based upon disposal of the material in question in a worst case management RCRA Subtitle D-like landfill scenario. The scenario assumed is quite conservative. Since levels exceeding the health-based criteria might be disposed in areas considered less protective than the leaking landfill scenario in the EPA CML, SRS is choosing a DAF of 10 rather than 100 .

Secondly, a DAF was chosen because soil studies at SRS have concluded that direct discharge of purge water at the well site does not increase substantially the concentrations of hazardous constituents. These studies concluded that after repeated applications of inorganic-contaminated groundwater, TCLP constituents would not exceed regulatory levels. Analysis of inorganic constituents have been conducted in two similar studies that include "Proposed Metal Study for the Purge Water Management Program, WSRC-RP-90-783, August 1990", and "Application of Inorganic Contaminated Ground Water for Soils and Compliance with Toxicity Characteristics Regulations, WSRC-MS-91-120". The latter study identified two surface soils types ubiquitous at SRS (Lakeland and Orangeburg soils) and on which tests were conducted to determine the retention ratios of TCLP constituents onto the soils. This study was conducted in both the laboratory with spiked water samples (with TCLP constituents) on SRS soil samples and in the field (in-situ) at a number of well sites with unspiked well purge water containing TCLP constituents. These studies conclude that soil adjacent to SRS monitoring wells that receive purge water will not accumulate inorganics such that they become a hazardous waste according to the RCRA TCLP definition. The effects of volatile organics transport from purge water released onto the ground surface results in interactions with the biosphere, soil, air, and soil moisture. Even though field screening instrumentation is qualitative, i.e. organic vapor analyzers (FID) and photovac detectors (PID), the sensitivity of these instruments is adequate to support inferences that little or no retention of organics in the soil is expected or will be observed.

The volumes of IDW purge water requiring management, and thus the associated costs, are also relevant. The lower the action level, the larger the volume and cost of the resulting material requiring management with no commensurate improvement in risk reduction being realized. The transition from the preceding IDW management strategy at SRS (generally using $100 \times$ MCLs for action levels) to the proposed IDW plan (DAF of 10 for aqueous IDW unless tritium is present for areas without listed waste and no DAF for listed waste areas) approximately triples the volume of material requiring management. Uniformly applying a DAF of 1 for all areas would increase sixfold the volume of material requiring management, compared to the DAF of 10.

Further. justification of the DAF of 10 for nonlisted aqueous IDW based on volumetric constraints. treatability/implementability constraints, and fate and transport appear below: 
a. Volumetric Constraints: The total estimated purge water volume at SRS is 441,000 gallons generated annually from all groundwater monitoring wells. Approximately $9 \%(39,000$ gallons) is being containerized and processed at the M1 air stripper and the remaining $91 \%$ ( 402,000 gallons) is discharged to the ground. Of the 441,000 gallons total purge water volume, approximately 183,000 gallons will require management assuming the action levels of the Revision 2 IDW Management Plan are employed. Of the 183,000 gallons, a subvolume each of 62,000 gallons will be processed at the F/H ETF upon completion of facility modifications in accordance with Appendix C; and 94,000 gallons will be treated at the M1 air stripper. There is no current treatment capacity for the remaining 27,000 gallons of listed/radisactive purge water. A favorable response to the letter of November 4, 1994 will enable this purge water to be accommodated by the F/H ETF. Alternately, as described in the IDW Management Plan, Section 4.2 "Listed-Radioactive Aqueous IDW Management", a treatment capacity must be engineered and constructed to process this purge water volume.

If the IDW management approach is to containerize and process all purge water at HBLs (i.e. DAF of 1), the volume requiring management is 361,000 gallons. Of this volume, a subvolume each of 94,000 gallons will be treated at the $M 1$ air stripper, and 27,000 gallons of listed/radioactive purge water, with the increased volume of 240,000 gallons of nonlisted purge water at the F/H ETF.

The following Table 2-2 summarizes the volumes of IDW requiring management under the scenarios: (1) current practice, (2) practice required by IDW Management Plan Revision 2 with nonlisted IDW purge water managed at 10x HBLs in Appendix A, (3) practice required by IDW Management Plan Revision 2 and management of nonlisted IDW purge water at HBLs in Appendix A.

\begin{tabular}{|l|c|c|c|}
\hline \multicolumn{3}{|c|}{ TABLE 2-2 - ANNUAL PURGE WATER SUMMARY (Gallons) } \\
\hline & $\begin{array}{c}\text { Current Practice } \\
100 \times \text { HBLs }\end{array}$ & $\begin{array}{c}\text { IDW Plan } \\
\text { Revision 2, } \\
\text { nonlisted at } \\
\text { 10x HBLs } \\
\text { in Appendix A }\end{array}$ & $\begin{array}{c}\text { IDW Plan } \\
\text { Revision 2, } \\
\text { nonlisted at } \\
\text { HBLs } \\
\text { in Appendix A }\end{array}$ \\
\hline Listed (containerized) - & N/A & $27,000(6 \%)$ & $27,000(6 \%)$ \\
\hline with Radioactive Constituents (MWMF) & $39,000(9 \%)$ & $94,000(21 \%)$ & $94,000(21 \%)$ \\
\hline $\begin{array}{l}\text { without Radioactive Constituents (AM Area, } \\
\text { Sanitary Landfill) }\end{array}$ & N/A & $62,000(14 \%)$ & $240.000(55 \%)$ \\
\hline $\begin{array}{l}\text { Nonlisted (containerized) - } \\
\text { with Radioactive and without Radioactive } \\
\text { Constituents, Metals (Burial Ground) }\end{array}$ & $402,000(91 \%)$ & $258,000(59 \%)$ & $80,000(18 \%)$ \\
\hline Discharge to Ground in Well Vicinity & $441,000(100 \%)$ & $441,000(100 \%)$ & $441,000(100 \%)$ \\
\hline TOTAL & & & \\
\hline
\end{tabular}

In summary, the management of IDW nonlisted purge water at 10x HBLs versus at HBLs results in a significant volume reduction of 178,000 gallons $(240,000-62,000)$ that would require management on an annual basis. This volume translates into a $\$ \underline{815,000}$ cost avoidance on an annual basis.

b. TreatmenU/mplementability Constraints: This volume increase of 178.000 gallons does present significant implementability constraints. Logistical problems also become significant: areas with 
large-scale groundwater impacts already have much infrastructure in place, such as graveled and graded roads. However, lowering action levels below a DAF of 10 would trigger management requirements at many additional areas, most of which lack adequate access or present other logistical difficulties. Some, such as the TNX Area (next to the Savannah River), remote sites in parts of the AM Area, and the Sanitary Landfill (areas adjacent to Upper Three Runs Creek), present ecological concerns as well: infrastructure improvements (i.e., road access) necessary to manage IDW would potentially damage the associated wetlands and at a minimum would require extensive permitting periods.

Additional relevant implementability constraints are as follows:

(1) Purchase of three additional tanker trucks would be required to collect and transport the increased volume (178,000 gallons) of purge water to the F/H Effluent Treatment Facility (F/H ETF).

(2) Assignment of three additional full-time drivers and at least one backup driver for the tanker trucks.

(3) Assignment of additional sampling crews to collect the purge water. It should be noted that the 178,000 gallon volume increase results from the need to collect purge water from an additional 536 wells.

(4) Regrade and gravel twelve (12) miles of well access roads to allow the tanker trucks to get to currently inaccessible wells sites.

(5) Perform additional road maintenance to allow continuous access by the tanker trucks.

(6) Assignment of additional facility operations personnel for unloading the tanker truck at the F/H ETF.

(7) Perform additional vehicle service maintenance on an annual basis.

These constraints also incur an increased administrative burden (i.e. training requirements, procedures, etc.) which must be accommodated on an annual basis.

c. Eate and Transport: The above noted volume, cost, and implementability constraints limit DOE's ability to manage the purge water without discharge at the well site. As noted previously, soil studies at SRS have concluded that direct discharge of purge water at the well site does not increase substantially the concentrations of hazardous constituents (Proposed Metal Study for the Purge Water Management Program, WSRC-RP-90-783, August 1990, and Application of Inorganic Contaminated Ground Water for Soils and Compliance with Toxicity Characteristics Regulations, W'SRC-MS-91-120). Further, these studies conclude that soil adjacent to SRS monitoring wells that receive purge water will not accumulate inorganics such that they become a hazardous waste according to the RCRA TCLP definition.

Additionally, based on extensive modeling and field studies by EPA (discussed in EPA/540/R94/101. Soil Screening Guidance, 12/94), supportive guidance has been developed for the selection and application of soil screening levels (SSLs) by the use of tools such as groundwater fate and transport models (from Ground Water Modeling Compendium, U.S.EPA, 1994, and Framework for Assessing Ground Water Model Applications, U.S.EPA, 1994). Methodologies in the Soil Screening Guidance included utilizing risk exposure pathways, considering background contamination, applying a dilution attenuation factor (DAF), as well as developing fate and transport modeling to identify levels of contamination requiring a response action.

\subsubsection{Aqueous IDW From Non-Listed Sources}

SRS will manage non-listed aqueous IDW resulting from well development and from the 
groundwater monitoring and sampling program in one of two ways as shown in Figure 2-3.

A list of SRS groundwater wells requiring purge water containerization is routinely generated and updated from a review of the historical groundwater quality database. For non-listed purge water, individual well purge water volumes with constituent concentrations exceeding the 10x HBLs in Appendix A will be containerized and treated at existing SRS treatment facilities that operate in accordance with applicable regulatory requirements. Individual volumes with constituent concentrations that do not exceed 10x HBLs in Appendix A will be discharged to the ground within the immediate area of generation. Aqueous IDW containing constituents that exceed the RCRA Toxicity Characteristic Leaching Procedure (TCLP) levels will be managed as a hazardous waste.

Decontamination solutions and rinsates from washing of sampling tools and PPE may include soap and water, isopropyl alcohol for volatile organic compound (VOC) stripping, and nitric acid for residual metals stripping. The dilute soap and water solutions will be discharged to the ground surface and the alcohol solutions will be allowed to evaporate. The nitric acid solutions will be neutralized and discharged at the site of generation. In all cases, the volume of decontamination solutions will be minimized.

\subsubsection{Non-Aqueous IDW From Non-Listed Sources}

Non-aqueous IDW is defined as those wastes generated from waste unit investigation activities which may or may not exceed the management levels in Appendix B. Non-aqueous IDW includes: soil cuttings, drilling fluids, well development water with total suspended solids greater than 100 $\mathrm{mg} / \mathrm{L}$ (see "Drilling Fluids" discussion Section 2.2.2) contaminated equipment, and PPE. SRS will manage these wastes as depicted in Figure $2-4$ and as discussed in the following paragraphs.

\section{Soil Cuttings}

Soil cuttings are defined as unconsolidated soil materials accumulated at the work site during environmental drilling or site characterization activities. Soils cutting are typically dry to moist sediments removed from the shallow subsurface but may include sediments from shallow semisaturated zones (i.e., perched water-table zones) in the subsurface.

Soil cuttings and other non-aqueous IDW generated inside the AOC will be placed into management units (MU) inside the $A O C$, as previously described in Section 2.1. The MU will be constructed as illustrated in Figure 2-2. The IDW will remain in the MU and will be dispositioned during time of final remedial actions.

Soil cuttings generated outside the AOC will be field screened for constituents of concern based upon process knowledge as discussed in Section 2.0. For constituents where field screening methods have not been developed to measure to the applicable health-based management levels, samples will be collected for laboratory analysis. Non-aqueous IDW with constituents of concern exceeding the management levels in Appendix B, but below TCLP levels, will be placed in a management unit within the related AOC, or disposed at SRS in accordance with the applicable requirements of the Westinghouse Savannah River Company (WSRC) 3Q-Environmental Compliance Manual and the WSRC Waste Acceptance Criteria Manual. Non-radioactive IDW meeting these criteria will be disposed in an appropriately permitted facility such as a sanitary landfill and suspect radioactive contaminated IDW will be disposed of in the Solid Waste Complex. Other appropriately permitted units such as iner material landfill units or industrial waste disposal units may be evaluated for use on a case-by-case basis. As noted in the implementation schedule (Appendix C) "Select Non-Hazardous Disposal Units" specific sites at SRS will be identified. 


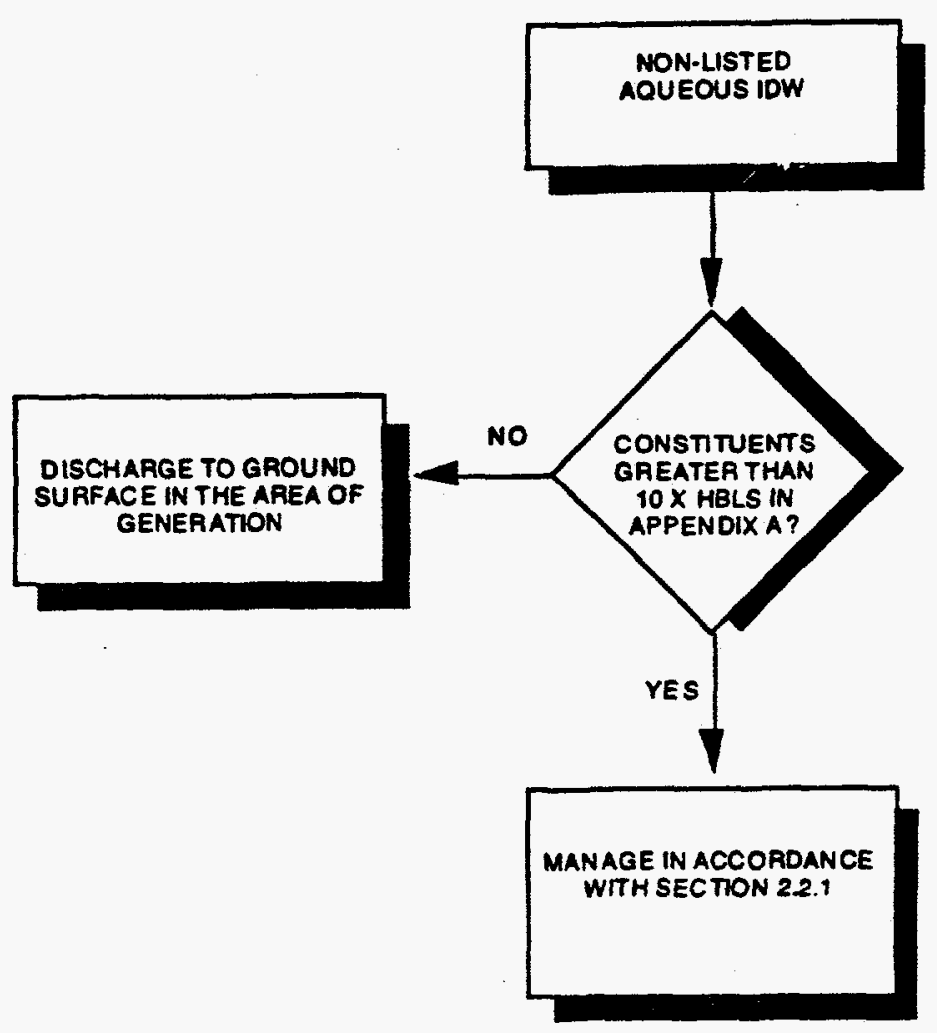

Figure 2.3 Aqueous IDW Management From Non-Listed Sources 


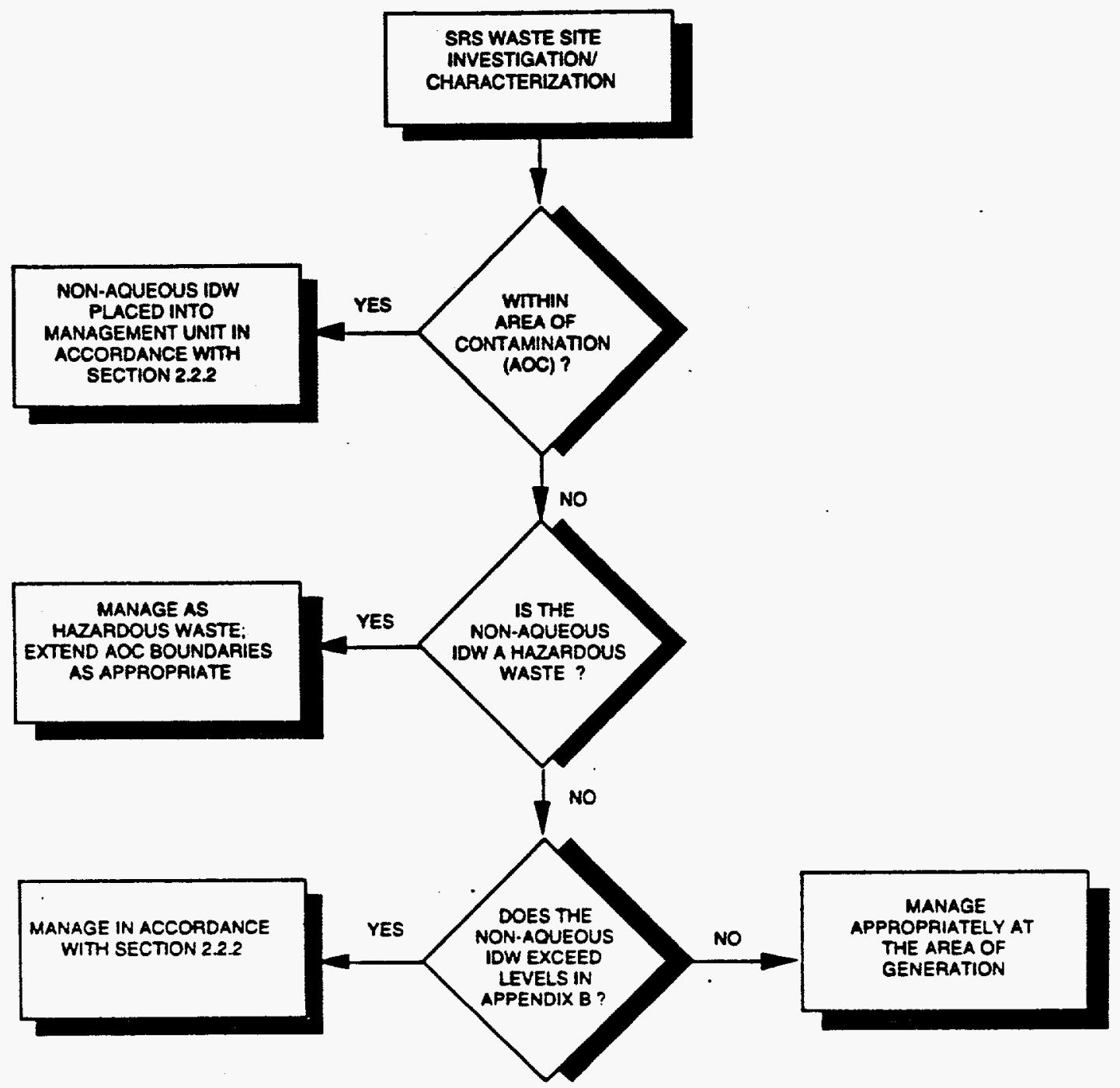

Figure 2-4 Non-Aqueous IDW Management From Non-Listed Sources 
Non-aqueous IDW with constituent levels exceeding the TCLP levels will be managed as a hazardous waste. If justified, the AOC boundaries will be extended and the non-aqueous IDW will be placed into management units inside the AOC. The soil cuttings that do not exceed the management levels in Appendix B will remain at the area of generation. Soil cuttings contaminated with tritium only will also remain at the area of generation.

Non-aqueous IDW with constituent levels exceeding the TCLP levels will be managed as a hazardous waste. If appropriate to facilitate management of $\mathrm{DWW}$, the approximate $A O C$ boundaries as defined based on the orange markers, will be reevaluated to consider whether the AOC boundaries are actually larger than the area defined by the orange markers. If justified, the AOC boundaries will be extended and the non-aqueous $\mathrm{DWW}$ will be placed into a MU inside the AOC. The soil cuttings that do not exceed the management levels contained in Appendix B will remain at the area of generation. Soil cuttings contaminated with tritium only will also remain at the area of generation.

At closed RCRA units, or areas where the extent of contamination is not clearly defined, or in areas with difficult or limited access, non-aqueous $\mathrm{DW}$ exceeding the levels in Appendix B will be staged in containers and characterized for final disposition. IDW with constituent concentrations levels less than the levels in Appendix B will be managed using appropriate practices such as land application.

Drilling Fluids

Drilling fluids (including well development water) will be field screened at intervals dependent upon unit-specific conditions. Field screening intervals will be identified in unit-specific work plans (if developed) for the respective waste units. Where field screening methods have not yet been developed for detection of constituents of concern at the levels in Appendix B, samples will be collected for laboratory analysis.

Well development water with constituent concentrations exceeding the levels contained in Appendix B will be managed and treated at existing industrial waste water treatment facilities at SRS. In the study that was conducted to assess the ability of the F/H Area Effluent Treatment Facility (ETF) to process the various IDW, it was determined that the primary concern is the amount of very fine solids from the drilling fluids and well development water. The technical assessment of this concern is that the F/H ETF can readily handle waters with less than $100 \mathrm{mg} /$ total suspended solids (TSS). If the TSS exceeds this level the decision to process the water would have to be made on a case to case basis, and if the level of TSS is greater than $1000 \mathrm{mg} /$, the F/H ETF will not accept the shipment. Therefore, since the drilling fluids and well development waters contain significant quantities of fine suspended solids, a pre-treatment process to clarify these waters will be required prior to processing at the ETF. Pilot scale process development work will be required; however, there is the highest level of confidence that the clarification process outlined below will be sufficient.

After the well has been installed, the drilling fluid and well development water will be pumped into a clarifier-type tank. Lime or an anionic polymer may be added to enhance the flocculation of the suspended solids. After the solids have been allowed to settle, the clarified water will be decanted and pumped into a tanker truck for transportation to the appropriate ETF. The solids residue in the bottom of the clarifier-type tank will be dispositioned with the other solids from the drilling operation.

Any drilling and decontamination fluids containing only tritium will not be containerized and treated. If drilling and well development fluids are contaminated with tritium and another 
constituent which exceeds levels in Appendix B, it will be managed according to the protocol for the other constituent.

\subsection{Management of IDW From Listed Sources}

SRS is implementing a program for the management of IDW from listed sources to achieve consistency with the Contained-In Policy. The fundamental principle of this program is that if a hazardous waste is contained in another media such as soil or groundwater, that combination is also to be managed as a hazardous waste. Thus, aqueous and non-aqueous IDW which contain listed constituents exceeding the levels in Appendix A or B will be managed as a hazardous waste.

For both aqueous and non-aqueous IDW, a phased-in implementation program is proposed and is further discussed in Section 4.2. This phased approach necessitates interim management activities as discussed in this sub-section until the appropriate SRS treatment systems and infrastructure can be established for full implementation.

IDW purge water generated outside the AOC which contains listed constituents exceeding the levels in Appendix A will be managed as a hazardous waste. IDW purge water generated inside the AOC which contains listed constituents exceeding the levels in Appendix A will be managed as a hazardous waste. Non-aqueous IDW generated outside the AOC which contains listed constituents exceeding the levels in Appendix B will be managed as hazardous waste. Nonaqueous IDW generated inside the AOC will be placed in a MU inside the AOC. Figure 2-5 illustrates the logic of this approach.

The mechanics for managing IDW purge water and non-aqueous IDW generated from non-listed sources as discussed in Sections 2.2.1 and 2.2.2, respectively, are applicable for the management of IDW generated from listed sources. The details are not repeated in this section. SRS will perform interim management of IDW generated from these waste units as detailed below.

\subsubsection{Aqueous IDW From Listed Sources}

\section{AM Area}

SRS will continue to manage purge water in the AM Area, a known source of listed hazardous waste at SRS. Individual purge water volumes with listed constituent concentrations exceeding the levels in Appendix A will be managed and treated at the M-1 Air Stripper facility. Individual volumes with constituent concentrations less than the levels in Appendix A will be discharged to the ground within the immediate area.

Sanitary Landfill

Another source known to have received listed hazardous waste at SRS is the Sanitary Landfill. Individual purge water volumes with constituent concentrations exceeding the levels in Appendix A will be treated at the M-1 Air Stripper facility as long as the constituents present are permitted for treatment at this facility. Individual volumes with constituent concentrations less than the levels in Appendix A will be discharged to the ground within the immediate area. 

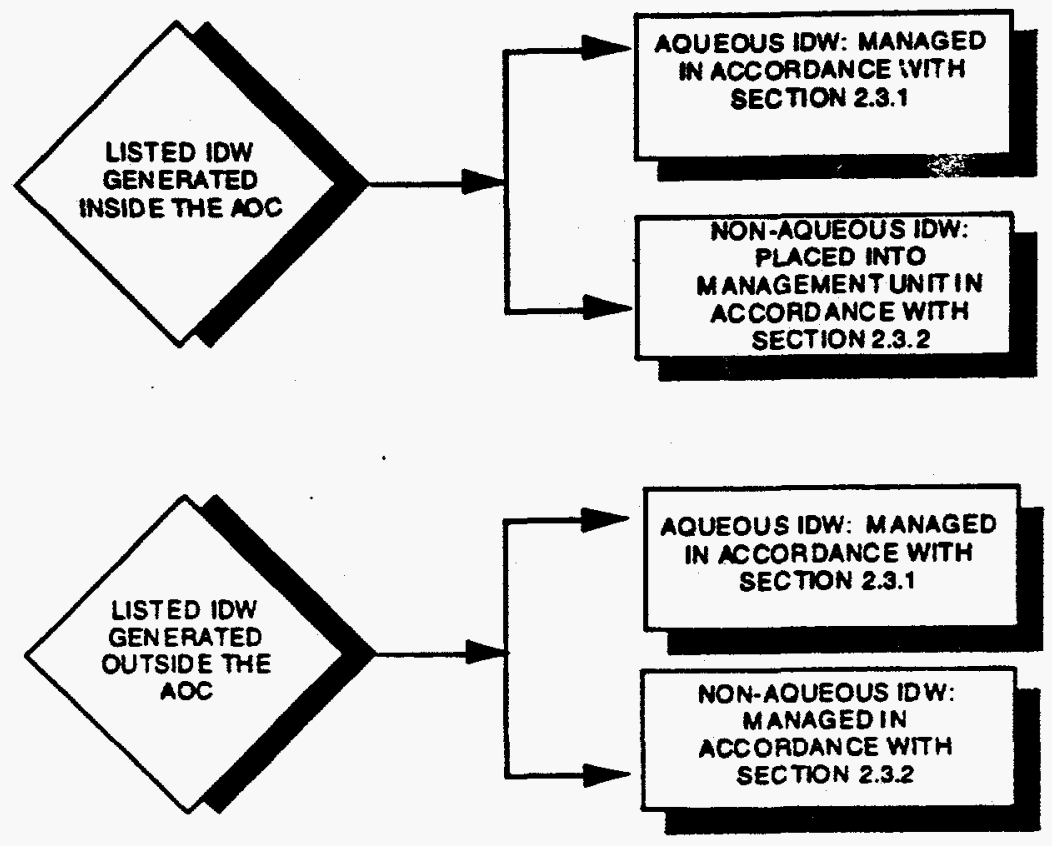

Figure 2-5. IDW Management From Listed Sources 


\section{Mixed Waste Management Facility (MWMF)}

Another source known to have received listed hazardous waste is the Mixed Waste Management Facility (MWMF). Characterization of contamination at the MWMF is being conducted pursuant to RCRA Interim Status regulations (R.61-79.265) through the Field Investigation Plan (FIP) for the Burial Grounds Complex. The methods contained in Phase I of the FIP, which has been approved by SCDHEC (Gorman to Cook, October 6, 1994), will continue to be employed throughout the unit-specific field work duration since this field activity is currently in progress and is being performed under an approved work plan.

Treatment facilities do not currently exist at SRS that are capable of treating purge water from the MWMF wells since it contains both listed and radioactive constituents. Section 4.2, entitled "Management Implementation for IDW from Listed Sources," provides a description of the alternative options SRS is pursuing and a schedule for implementation.

\subsubsection{Non-Aqueous From Listed Sources}

The mechanics for managing non-aqueous IDW generated from non-listed sources as discussed in Section 2.2.2 are applicable for the management of IDW generated from listed sources. The management levels for non-aqueous IDW are different from the levels for aqueous IDW. Management levels for non-aqueous IDW are contained in Appendix B. The details of nonaqueous IDW management are not repeated in this section. 


\subsection{IDW MINIMIZATION}

IDW minimization is a fundamental component of the SRS program to manage by-products of unit investigations. Efforts in this area will reduce the volume of waste materials that must be managed. The program builds on existing SRS initiatives of IDW management and includes the following elements:

\section{Well Minimization}

The ability to characterize groundwater conditions using fast, reliable methods is crucial is IDW minimization. To support this strategy, SRS has tested and is in the process of further assessing characterization methods which will maximize the efficiency of these types of investigations while minimizing the number of monitoring well installations.

As an example, SRS has conducted a field evaluation of a prototype device (the Hydropunch ${ }^{\mathrm{TM}}$ ) that provides a less invasive technique for collecting groundwater samples. The evaluation resulted in regulatory approval to use the Hydropunch ${ }^{\mathrm{TM}}$ (and similar devices) as a screening tool for waste unit characterizations. This method provides additional data for locating permanent monitoring wells for assessment and plume definition. The Hydropunch ${ }^{\mathrm{TM}}$ has subsequently been used at several sites in M Area, D Area, K Area, and at the Sanitary Landfill.

\section{Purge Water Reduction}

Several methods are being evaluated to potentially reduce the amount of purge water generated during sampling activities at SRS:

- micropurging-Using dedicated low-flow sampling devices to selectively remove only water in the well directly opposite the well screen versus conventional method of evacuating the entire column of water standing in the well and mixing in flow with stagnant water. Experimentation is currently being considered to evaluate the accuracy and reliability of analytical data collected following micropurging.

- two inch diameter wells-SRS has performed a feasibility evaluation of the Grundfos Redi-Flo ${ }^{\text {TM }}$ variable rate, two-inch submersible pump, to determine if this pump performs effectively inside a two-inch well. Consequently, in cenain cases, SRS began efforts in 1994 to step down from the four-inch diameter wells to two-inch diameter well installations; e.g. A/M Area. Two-inch diameter wells require less water to be purged during well development and prior to groundwater sampling. Where applicable, SRS will continue to install two inch diameter monitoring wells.

- packer equipment-The use of a casing packer to seal the upper portion of a well from the screened interval would reduce the amount of stagnant water that requires purging prior to sampling. Purge water from newly installed wells that fails HBL criteria action level criteria could be fitted with a packer that isolates the screened zone. SRS is currently evaluating methods for retrofitting existing wells with packers. The use of packer equipment would be limited to 4 -inch diameter wells screened below the water table containing contaminants in concentrations above HBL criteria. 


\section{Less Invasive Drilling Techniques}

Technologies consisting of direct push methods of data collection (e.g., cone penetrometer testing) and sonic drilling are being evaluated. These technologies provide real-time geophysical, hydrological, and geochemical data that allow for design improvements in monitoring well networks. Improved monitoring well network design results in fewer permanent wells needed to obtain the necessary data, thus reducing the amount of $\mathrm{DDW}$ generated from well installation.

\section{Waste Minimization Drilling Techniques}

SRS intends to determine the feasibility of drilling techniques which produce less IDW than techniques currently in general use. These techniques include the reverse air rotary drilling method. This water/mud-free method can yield less liquid and slurry-type IDW and allow recovery of drilling-related solids.

\section{Sample Reduction/Optimization}

Reduction in sampling frequency reducing the number of analytical parameters, and possibly removing selected wells from monitoring networks are options that are being evaluated. Each reduction will be evaluated in terms of regulatory compliance and data needs.

SRS will continue to solicit input from industry on potential IDW minimization technologies via avenues such as vendor forums and technology information exchange meetings.

\section{Pore Water Analysis}

In an effort to shorten the turnaround time for IDW analysis and characterization, SRS will be evaluating the use of pore water analysis. Pore water would be extracted from a non-aqueous IDW sample and analyzed, in lieu of analysis of the total constituent concentrations in the non-aqueous matrix. SRS proposes to use an approach similar to the one listed below, to determine the appropriate management for IDW.

1. Acquire a representative sample of non-aqueous IDW.

2. Add distilled water, if necessary, to saturate the IDW sample.

3. By filtration, express sufficient aqueous subsample to analyze for constituents deemed potentially present.

4. Sample aqueous subsample according to the approved well monitoring protocol (e.g., container type and volume, preservative) used by the SRS Environmental Monitoring Section.

5. Analyze aqueous subsample by approved methods for constituents deemed potentially present.

6. Manage non-aqueous material according to the management category appropriate to the aqueous subsample, as determined by the analytical results. 


\subsection{IMPLEMENTATION SCHEDULE}

Implementation of this management plan in a reasonable and timely fashion is crucial to its success. Implementation will include the following modifications to the current SRS approach and procedures, to enhance the ability to manage IDW in a proper and efficient manner protective of human health and the environment. SRS proposes that the field activities currently in process under existing approved RFI/RI work plans will continue in force through the unit-specific field work duration.

\subsection{Management Implementation for IDW From Non-Listed Sources}

The following activities will be required prior to managing IDW generated from non-listed sources. A schedule for these activities is included in Appendix C, in the section entitled "Non-Listed Radioactive Aqueous IDW Management."

\section{F/H Effluent Treatment Facility (F/H ETF) Modification}

The F/H Effluent Treatment Facility serves SRS operations by treating water from various process activities and stormwater management. A transfer station has been designed to allow for the transfer of purge water from tanker vehicles to the F/H ETF (Note: the design has been completed). This modification includes piping additions to the exterior of the facility, but will not require process modifications. [Note: The material to construct the transfer station has been procured.] The industrial wastewater treatment (IWT) permit modification has been submitted to SCDHEC for approval and is required prior to the start of construction of the transfer station.

Treating purge water at the F/H ETF is dependent on two factors: modifying the F/H ETF to receive the water and purchasing a tanker truck to collect the water. The tanker truck contract was awarded in September 1994. The tanker is estimated to arrive at SRS approximately seven months (vehicle fabrication time) from contract placement. Current estimates place the tanker at SRS in April 1995. Thus, SRS has moved forward to complete the design and award the tanker truck contract. The IWT Permit was approved in December 1994 and construction commenced in January 1995. Phased-in management of the non-listed radioactive purge water will commence in July 1995.

Phased-in management is necessary since containerizing and treating the purge water during well sampling takes longer than discharging the purge water directly to the ground surface. SRS will be required to collect and treat in the F/H Effluent Treatment Facility purge water from over 250 wells. Since all of the wells have to be sampled on a quarterly basis, the schedule to sample all wells on time is very ambitious. SRS plans to phase in the collection and treatment of purge water by beginning with one third of the wells the sampling quarer after the tanker truck is received. The next sampling quarter, purge water from two thirds of the wells will be collected and treated, and finally, in the third sampling quarter, and all quarters thereafter, all purge water requiring containerization will be collected and treated. Phasing in the collection of purge water will allow SRS to confirm that the regulatory required sampling program will not be compromised, and will allow necessary adjustments to the purge water collection program.

\subsection{Management Implementation for IDW From Listed Sources}

The following activities will be required prior to managing purge water generated from listed sources. Schedules for these listed IDW management activities are included in Appendix $C$ in the sections entitled "Listed Non-Radioactive Aqueous IDW Management" and "Listed Radioactive Aqueous IDW Management". 
SRS will manage purge water from a known source of listed hazardous waste, as well as other contaminated media that is known to contain listed hazardous waste constituents, as a hazardous waste. SRS will continue to maintain compliance with applicable Department of Transportation and RCRA Subtitle C requirements for the IDW tanker truck. The purge water tanker truck is placarded when aqueous IDW is present and is brought to the $A / M$ Area purge water disposal facility (for VOC contaminated groundwater) for processing. The tanker truck is unloaded within the same shift that the aqueous IDW is accumulated. If the vehicle cannot be unloaded within the same shift, the tanker truck is placed in a designated staging area located within M-Area. These routine operations are conducted in compliance with the applicable RCRA Subtitle C requirements.

\section{Listed Non-Radioactive Aqueous IDW Management}

Purge water at AM Area wells with constituent concentrations exceeding HBLs will continue to be managed as IDW and will be treated at the M-1 Air Stripper facility. Management of purge water from the Sanitary Landfill with VOC constituent concentrations exceeding HBLs will begin in accordance with the schedule in Appendix C.

\section{Listed Radioactive Aqueous IDW Management}

Treatment capacity does not currently exist at SRS for the processing of purge water which contains both listed and radioactive constituents. Not withstanding the previously discussed " $F / H$ Effluent Treatment Facility (F/H ETF) Modification", the F/H ETF cannot process purge water which contains both listed and radioactive constituents due to the "Derived-From Rule". SRS has submitted a request for interpretation of the March 24, 1986 Federal Register for review and disposition by EPA and SCDHEC which could potentially provide for the treatment at the F/H ETF of purge water which contains listed and radioactive constituents. In parallel with the preparation of the submittal to EPA and SCDHEC, SRS has completed a preliminary engineering study to evaluate the treatment altematives for this waste stream and has concluded that a system consisting of a granular activated carbon unit and an accumulation tank would be a viable approach for removing the listed constituents to below the levels in Appendix A. These permitted systems are not currently available at SRS and thus the necessary engineering, procurement, and construction must be scheduled. SRS will continue the engineering of the system while awaiting the EPA and SCDHEC disposition of the request for interpretation. The necessary engineering procurement and construction will be performed in accordance with the schedule in Appendix C. 


\section{REFERENCES}

55 FR 11813, 1990. Vol. 55, No. 61.

55 FR 11798, 1990. Toxicity Characteristics Revisions.

58 FR 48092, 1993. Land Disposal Restrictions for Newly Identified and Listed Hazardous Wastes and Hazardous Soils. Section 260.42.

Bergren, C. L., et. al., Application of Inorganic Contaminated Groundwater for Soils and Compliance With Toxicity Characteristic Regulations. WSRC-MS-91-120, August 1991.

Bergren, C. L., et. al., Proposed Metal Study for the Purge Water Management Program. WSRCRP-90-783, August 1990.

Camp Dresser \& McKee Inc., WSRC-RP-89-1198, FINAL REPORT: Numerical Simulation of Groundwater Flow and Contamination Transport at the K, L, and P Areas of the Savannah River Site, Aiken, S.C.

EPA (U.S. Environmental Protection Agency), 1994. Groundwater Modeling Compendium. Washington, DC.

EPA (U.S. Environmental Protection Agency), 1994. Framework for Assessing Groundwater Applications. Washington, DC.

EPA (U.S. Environmental Protection Agency), 1994. Soil Screening Guidance. Document \#EPA/540/R-94/101, Washington, DC.

EPA (U.S. Environmental Protection Agency), 1994. Technical Background Document for Soil Screening. Document \#EPA/540/R-94/102, Washington, DC.

EPA (U.S. Environmental Protection Agency), 1991. Guide to Management of InvestigationDerived Waste. Document \#9345.3-03FS, Washington, DC.

Fay, W.M. and J.B. Pickett, DPST-87-260, Documentation of 1982 Soil Analyses to Determine the Natural Background Radioactivity in SRP Surface Soils, January 29, 1987, E. I. du Pont de Nemours \& Co., Inc., Savannah River Laboratory, Aiken, SC.

Gorman, A.(SCDHEC) to Cook, J.W. (WSRC), October 6, 1994. Letter regarding Mixed Waste Management Facility Field Investigation Plan.

Holcomb, H. P., ECSD-SGS-95-0020, Radionuclide Background Levels in Production Unimpacted SRS Soils Versus Soil PRGs (U), January 10, 1995, Site Geotechnical Services Dept., Westinghouse Savannah River Co., Savannah River Site, Aiken, SC.

Looney, B. B., et. al., WSRC-RP-90-1031, Geochemical and Physical Properties of Soils and Shallow Sediments at the Savannah River Site (U). August 31, 1990, Westinghouse Savannah River Co.. Savannah River Site, Aiken, SC.

Thayer, P. A., GHBX-33(83), Results of Natural Uranium Resource Evaluation (NURE) Detailed Sampling in the Aiken County, South Carolina Area, November 1983, E. I. du Pont de Nemours \& Co., Inc., Savannah River Laboratory, Aiken. SC. 
WSRC-RP-90-424-1 Tritium in the Savannah River Site Environment (U), Savannah River Site, Aiken, SC.

WSRC Manual-3Q, Current Version. Environmental Compliance Manual. WSRC 3Q, Savannah River Site, Aiken, SC.

WSRC-RP-90-1299, Environmental Information Document; Reactor Seepage Basins (U), Savannah River Site, Aiken, SC.

WSRC Manual-1S, Savannah River Site Waste Acceptance Criteria Manual, Revision 2, February $28,1992$. 


\section{APPENDIX A}

\section{SRS INVESTIGATION-DERIVED WASTE MANAGEMENT PLAN (U):}

HEALTH-BASED LEVELS FOR

\section{AQUEOUS IDW}

CONTAINERIZATION DETERMINATIONS 
This page is intentionally lefi blank. 
This table applies to aqueous IDW only and lists constituents used to determine whether or not aqueous IDW requires containerization and subsequent management, in some cases as RCRA hazardous waste. Note that radionuclides are included in this list because healthbased levels have been promulgated for at least some of them, even though they are not hazardous according to the definition of the South Carolina Hazardous Waste Management Regulations (SCHWMR) R.61-79.

Most numerical limits are based on Primary Drinking Water Standards (PDWS) of the Safe Drinking Water Act (SDWA) promulgated as Maximum Contamination Levels, (MCLs). Note that enforceable MCLs supersede proposed MCLs for any given constituent and that interim MCLs apply only to the two radionuclides for which activity-based limits are tabulated: Strontium-90 and Tritium, in Table A of R61-58.5L(2). Note also that Beta radiation's MCL is not activity-based; the table presents the best technical judgment of a limit appropriate for SRS constituents of concem and is annotated Est. PDWS. Enforceable MCLs are annotated as PDWS in the rightmost column of the following table; interim MCLs are annotated as Int. PDWS. The limit for Cu (copper) is a Treatment Technology standard rather than an $\mathrm{MCL}$ and $\mathrm{SO}_{4}$ (sulfate) is based on a deferred MCL. These are annotated, respectively, as PDWS TI and Def. PDWS. Proposed MCLs, which are not yet enforceable, are annotated as Prop. PDWS.

MCLs conflict or are absent for a few SCHWMR constituents; in these cases, limits are set at 0.01 times the SCHWMR Toxicity Characteristic Leaching Protocol (TCLP) limit for constituents present in the TCLP list in Table 1 of R.61-79 \$261.24 or are set at the values in Table 1 of R.61-79 \$264.94(a)(2), as appropriate. The former are annotated as TCLP/100 and the latter as SCHWMR. Note that limits for three TCLP constituents are Practical Quantitation Limits (PQL) rather than health-based limits (see footnote 3); these limits cannot be reduced without falling below the $P Q L$ and are thus transferred into the Appendix unchanged. These three constituents (2,4-Dinitrotoluene, Hexachlorobenzene, and Pyridine) are annotated as TCLP(POL).

Limits for most remaining constituents are set to the current values of the EPA Region II's Preliminary Remediation Goals (PRG) for tap water, annotated as EPA-III PRG. A few limits represent estimated SRS background levels based on those typically observed in SRS monitoring wells; such values were used if and only if no health-based standard could be found or inferred and are annotated as Technical.

Several regulatory sources are cited as the basis for numerical limits. The order of priority for cases in which a limit is set for a paricular constituent in multiple citations is as follows:

1) SCHWMR, which includes pH; toxic metals; and TCLP constituents;

2) SDWA, which includes MCLs and interim MCLs; Treatment Technology limits (MCL alternative); proposed MCLs; and deferred MCLs (i.e., sulfate);

3) PRGs;

4) Best technical estimate of SRS background values for the few remaining constituents. 


\section{NOTES}

1) Units represent either activity (picoCuries, or $\mathrm{pCi}$ ) or mass (milligrams, mg, or nanograms, ng) per liter (L) or milliliter ( $\mathrm{mL}$ ).

2) EMS designators are used internally within the SRS groundwater database.

3) The CAS number is from the Chemical Abstracts Service Registry and is unique to each identified chemical or mixture of chemicals. Some analytes lack CAS numbers due to non-uniqueness (e.g., an analyte which groups ell compounds containing a particular ion or element, such as metals).

4) The chemical name tabulated is that which is in common use and may not match the CAS name. Some analytes have been reported in multiple EMS designators, such as $2 \mathrm{HXONE}$ and MIBK; in all such cases, the CAS number, if defined, is identical.

5) A summary of the columns in this table is as follows, from left to right:

a) EMS Designator used intemally at SRS, 1-6 alphanumeric characters.

b) Numerical limit applicable to aqueous $\mathrm{DWW}$ used in the calculation of whether or not the material requires containerization or treatment.

c) Unit of measurement applicable to the numerical limit in the previous column.

d) Chemical name in common use.

e) CAS number, for cross-verification between chemical names that may differ between source documents.

f) Source of the numerical limit applied: PDWS; TCLP; Technical; etc. 


\begin{tabular}{|c|c|c|c|c|c|}
\hline $\begin{array}{l}\text { SRS } \\
\text { EMS } \\
\text { Desig } \\
\end{array}$ & $\begin{array}{l}\text { Health- } \\
\text { Based } \\
\text { Limit }\end{array}$ & Units & $\begin{array}{l}\text { Common } \\
\text { Chemical Name }\end{array}$ & $\begin{array}{c}\text { CAS } \\
\text { Numbor }\end{array}$ & $\begin{array}{c}\text { Souree } \\
\text { of } \\
\text { HEL }\end{array}$ \\
\hline 111TCE & 0.2 & $\mathrm{mg} / \mathrm{L}$ & 1,1,1-Trichloroethane & $000071-55-6$ & PDWS \\
\hline 112TCE & 0.005 & $\mathrm{mg} / \mathrm{L}$ & 1,1,2-Trichloroethane & $000079-00-5$ & PDWS \\
\hline 11DCLE & 0.81 & $\mathrm{mg} / \mathrm{L}$ & 1,1-Dichloroethane ${ }^{-}$ & $000075-34-3$ & EPA-III PRG \\
\hline 11DCE & 0.007 & $\mathrm{mgl}$ & 1,1-Dichloroethylene & $000075-35-4$ & PDWS \\
\hline $124 \mathrm{TCB}$ & 0.07 & $\mathrm{mg} / \mathrm{L}$ & 1,2,4-Trichlorobenzene & $000120-82-1$ & PDWS \\
\hline $12 \mathrm{DB3P}$ & 0.0002 & $\mathrm{mg} / \mathrm{L}$ & 1,2-Dibromo-3-chloropropane & $000096-12-8$ & PDWS \\
\hline $120 B E$ & $7.50 E-07$ & $\mathrm{mgl}$ & 1,2-Dibromoethane & $000106-93-4$ & EPA-III PAG \\
\hline 12DCLB & 0.6 & $\mathrm{mg} / \mathrm{l}$ & 1,2-Dichlorobenzene & $000095-50-1$ & PDWS \\
\hline 12DCLE & 0.005 & $m g / 2$ & 1,2-Dichloroethane & $000107-06-2$ & PDWS \\
\hline 12DCLP & 0.005 & mol & 1.2-Dichloropropane & $000078-87-5$ & PDWS \\
\hline T12DCE & 0.1 & $\mathrm{mg} / \mathrm{L}$ & 1,2-trans-Dichloroethylene & $000156-60-5$ & PDWS \\
\hline OXYLEN & 10 & $\mathrm{mgl}$ & $1,2-$ Xylene & $000095-47-6$ & PDWS \\
\hline MXYLEN & 10 & $\mathrm{mg} / \mathrm{L}$ & 1,3-Xylene & $000108-38-3$ & PDWS \\
\hline 14DCLB & 0.075 & $\mathrm{mg} / \mathrm{L}$ & 1,4-Dichlorobenzene & $000106-46-7$ & PDWS \\
\hline $250 \mathrm{CCB}$ & 0.0005 & mgl & $2,2^{\prime}, 3,3^{\prime}, 4,4^{\prime}, 5,5^{\prime}$-Octachlorobipheny & $001335-36-3$ & PDWS \\
\hline $26 \mathrm{HPCB}$ & 0.0005 & $m g h$ & $2,2,3,4,4,5,6$-heptachlorobiphenyl & $001335-36-3$ & PDWS \\
\hline $25 \mathrm{HPCB}$ & 0.0005 & $\mathrm{mgl}$ & $2,2,3,4,5,5,6$-Heptachlorobipheny & $001335-36-3$ & PDWS \\
\hline $25 \mathrm{HXCB}$ & 0.0005 & $\mathrm{mg} / \mathrm{L}$ & 5 -Hexachlorobipheny & $001335-36-3$ & PDWS \\
\hline $245 P C B$ & 0.0005 & $\mathrm{mg} / \mathrm{L}$ & $2,2,4,5,5^{\prime}$-Pentachlorobipheny & $001335-36-3$ & PDWS \\
\hline $2255 \mathrm{CB}$ & 0.0005 & $\mathrm{mg} / \mathrm{L}$ & 2,2',5,5'-Tetrachlorobiphenyl & $001335-36-3$ & PDWS \\
\hline $225 \mathrm{TCB}$ & 0.0005 & $\mathrm{mgl}$ & 2.2'.5-Trichlorobiphenyl & $001335-36-3$ & PDWS \\
\hline $2345 \mathrm{CB}$ & 0.0005 & $\mathrm{mgh}$ & 2,3,4,5-Tetrachlorobiphenyl & $001335-36-3$ & PDWS \\
\hline C3TCDD & 4.30E-04 & $\mathrm{ngh}$ & 2,3,7,8-TCOD (Dioxin) & $001746-01-6$ & EPA-III PRG \\
\hline $24 D C B$ & 0.0005 & mgl & 2,4"-Dichlorobiphenyl & $001335-36-3$ & POWS \\
\hline 245TCP & 4 & $m g / L$ & 2.4.5-Trichlorophenol & $000095-95-4$ & TCLP/100 \\
\hline 246TCP & 0.02 & $m g / L$ & 2,4,6-Trichlorophenol & $000088-06-2$ & TCLP/100 \\
\hline 240 & 0.07 & $m g / l$ & $2,4-D$ & $000094-75-7$ & PDWS \\
\hline DCAA & 0.024 & $\mathrm{mg} / \mathrm{l}$ & 2.4-Dichlorophenylacetic Acid & & Technical \\
\hline 24DNT & 0.13 & $\mathrm{mg} / \mathrm{L}$ & 2,4-Dinitrotoluene & $000121-14-2$ & TCLP (PQL) \\
\hline 2CLP & 0.18 & mgl & 2-Chlorophenol & $000095-57-8$ & EPA-III PRG \\
\hline $2 \mathrm{HXONE}$ & 0.033 & $\mathrm{mg} / \mathrm{L}$ & 2-Hexanone & $000591-78-6$ & Technical \\
\hline 4CL3MP & 618 & $\mathrm{mgh}$ & 4-Chloro-3-methylphenol & $000059-50-7$ & Technical \\
\hline 4NP & 2.3 & $\mathrm{mgh}$ & 4-Nitrophenol & $000100-02-7$ & EPA-III PRG \\
\hline ACET & 3.7 & $\mathrm{mg} / \mathrm{L}$ & Acetone & $000067-64-1$ & EPA-III PRG \\
\hline$A C 225$ & 113 & $\mathrm{pCi}$ & Actinium-225 & $014265-85-1$ & Prop. PDWS \\
\hline$A C 227$ & 1.27 & pcil & Actinium-227 & $014952-40-0$ & Prop. PDWS \\
\hline$A C 228$ & 3270 & poin & Actinium-228 & $014331-83-0$ & Prop. PDWS \\
\hline$A L$ & 37 & $\mathrm{mgl}$ & Aluminum & NO CAS RN & EPA-III PRG \\
\hline ALDIS & 37 & $\mathrm{mgl}$ & Aluminum, Dissolved & NO CAS RN & EPA-III PRG \\
\hline ALTOT & 37 & $\mathrm{mg} / \mathrm{L}$ & Aluminum, Total & NO CAS AN & EPA-III PRG \\
\hline AM241 & 6.34 & pcir & Americium-241 & $014596-10-2$ & Prop. PDWS \\
\hline$A M$ & 4 & pCin & Americium-241/243 & NO CAS AN & Prop. PDWS \\
\hline AM242 & 5340 & pCin & Americium-242 & $013981-54-9$ & Prop. PDWS \\
\hline AM242M & 1.27 & $\mathrm{pCi} /$ & Americium-242m & $013981-54-9(\mathrm{~m})$ & Prop. PDWS \\
\hline AM243 & 6.37 & pCir & Americium-243 & $014993-75-0$ & Prop. PDWS \\
\hline $\mathrm{NH3}$ & 1 & $\mathrm{mgl}$ & Ammonia & $007664-41-7$ & EPA. III PRG \\
\hline
\end{tabular}




\begin{tabular}{|c|c|c|c|c|c|}
\hline $\begin{array}{l}\text { SRS } \\
\text { EMS } \\
\text { Desig } \\
\end{array}$ & $\begin{array}{l}\text { Heath- } \\
\text { Based } \\
\text { Limlt }\end{array}$ & Units & $\begin{array}{l}\text { Common } \\
\text { Chemical Name }\end{array}$ & $\begin{array}{c}\text { CAS } \\
\text { Number }\end{array}$ & $\begin{array}{c}\text { Source } \\
\text { of } \\
\mathrm{HBL}\end{array}$ \\
\hline NH3N2 & 1.65 & mgl & Ammonia as Nitrogen & $007664-41-7$ & EPA-III PRG \\
\hline SB & 0.006 & $m g /$ & Antimony & NO CAS RN & PDWS \\
\hline SBDIS & 0.006 & $\mathrm{mg} / \mathrm{L}$ & Antimony, Dissolved & NO CAS RN & PDWS \\
\hline SBTOT & 0.006 & $\mathrm{mg} / \mathrm{L}$ & Antimony, Total & NO CAS AN & PDWS \\
\hline SB122 & 810 & pCin & Antimony-122 & $014374-79-9$ & Prop. PDWS \\
\hline $\mathbf{S B 1 2 4}$ & 563 & pCin & Antimony-124 & $014683-10-4$ & Prop. PDWS \\
\hline SB125 & 1940 & pcin & Antimony-125 & $014234-35-6$ & Prop. PDWS \\
\hline 58126 & 544 & pCin & Antimony-126 & $015756-32-8$ & Prop. PDWS \\
\hline SB126M & 58500 & pCil & Antimony-126m & $015756-32-8(m)$ & Prop. PDWS \\
\hline SB127 & 818 & pCin & Antimony-127 & $013968-50-8$ & Prop. PDWS \\
\hline SB129 & 3090 & pCin & Antimony-129 & $014331-88-5$ & Prop. PDWS \\
\hline AS & 0.05 & mgl & Arsenic & NO CAS RN & PDWS \\
\hline ASDIS & 0.05 & $\mathrm{mg} \mathbf{L}$ & Arsenic, Dissolved & NOCAS RN & PDWS \\
\hline ASTOT & 0.05 & $\mathrm{mg} / \mathrm{L}$ & Arsenic, Total & NO CAS RN & PDWS \\
\hline AS73 & 7850 & pCin & Arsenic-73 & & Prop. PDWS \\
\hline AS74 & 1410 & $\mathrm{pCin}$ & Arsenic-74 & & Prop. PDWS \\
\hline AS76 & 1060 & pcin & Arsenic-76 & & Prop. PDWS \\
\hline AS77 & 4330 & pCin & Arsenic-77 & & Prop. PDWS \\
\hline AT217 & $4.27 E+08$ & pCir & Astatine-217 & $017239-90-6$ & Prop. PDWS \\
\hline ATZ & 0.003 & mgll & Atrazine & $001912-24-9$ & $\begin{array}{l}\text { PDWS } \\
\end{array}$ \\
\hline $\mathrm{BA}$ & 2 & $\mathrm{mg} / \mathrm{L}$ & Barium & NO CAS RN & PDWS \\
\hline BADIS & 2 & $\mathrm{mgl}$ & Barium, Dissolved & NO CAS RN & PDWS \\
\hline BATOT & 2 & mgll & Barium, Total & NO CAS RN & PDWS \\
\hline BA131 & 2950 & $\mathrm{pCi}$ & Barium-131 & $014914-75-1$ & Prop. PDWS \\
\hline BA133 & 1520 & $\mathrm{pCin}$ & Barium-133 & $013981-41-4$ & Prop. PDWS \\
\hline BA133M & 2620 & $\mathrm{pCin}$ & Barium-133m & $013981-41-4(m)$ & Prop. PDWS \\
\hline BA137M & 2150000 & $\mathrm{pCi}$ & Barium-137m & $013981-97-0(m)$ & Prop. PDWS \\
\hline BA139 & 13800 & $\mathrm{pCin}$ & Barium-139 & $014378-25-7$ & Prop. PDWS \\
\hline BA140 & 582 & $\mathrm{pCin}$ & Barium-140 & $014798-08-4$ & Prop. PDWS \\
\hline $\mathrm{C} 6 \mathrm{H6}$ & 0.005 & $\mathrm{mg} / \mathrm{L}$ & Benzene & $000071-43-2$ & PDWS \\
\hline BAPYR & 0.0002 & $\mathrm{mg} / \mathrm{L}$ & Benzo(a)pyrene & $000050-32-8$ & POWS \\
\hline $\mathrm{BE}$ & 0.004 & $\mathrm{mgh}$ & Beyllium & NO CAS RN & PDWS. \\
\hline BEDIS & 0.004 & $\mathrm{mgl}$ & Beryllium, Dissolved & NO CAS RN & PDWS \\
\hline BETOT & 0.004 & $\mathrm{mg} / \mathrm{L}$ & Beryllium. Total & NO CAS RN & PDWS \\
\hline BE7 & 43500 & $\mathrm{pCin}$ & Beryllium-7 & $013966-02-4$ & Prop. PDWS \\
\hline B2EHP & 0.006 & $m g / L$ & Bis(2-ethylhexyl) Phthalate & $000117-81.7$ & PDWS \\
\hline B1206 & 656 & pCir & Bismuth-206 & $015776-19-9$ & \begin{tabular}{|l|} 
Prop. PDWS \\
\end{tabular} \\
\hline $\mathrm{B} 1207$ & 1010 & $\mathrm{pCin}$ & Bismuth-207 & $013982 \cdot 38.2$ & \begin{tabular}{|l|} 
Prop. PDWS \\
\end{tabular} \\
\hline $\mathrm{B} 1210$ & 1010 & $\mathrm{pCil}$ & Bismuth-210 & $014331.79-4$ & Prop. PDWS \\
\hline $\mathrm{Bl} 211$ & 156000 & pCir & Bismuth-211 & $015229-37-5$ & Prop. PDWS \\
\hline BI212 & 5200 & $\mathrm{pCi}$ & Bismuth-212 & $014913-49-6$ & \begin{tabular}{|l|} 
Prop. PDWS \\
\end{tabular} \\
\hline$B 1213$ & 15000 & pCin & Bismuth-213 & $015776-20-2$ & Prop. PDWS \\
\hline B1214 & 18900 & $\mathrm{pCi} / \mathrm{L}$ & Bismuth-214 & $014733-03-3$ & \begin{tabular}{|l|} 
Prop. PDWS \\
\end{tabular} \\
\hline $\mathrm{B}$ & 3.3 & $\mathrm{mgl}$ & Boron & N/A & EPA-III PRG \\
\hline BDIS & 3.3 & $\mathrm{mg} / \mathrm{L}$ & Boron. Dissolved & N/A & EPA-III PRG \\
\hline BTOT & 3.3 & $m g h$ & Boron. Total & N/A & EPA-III PRG \\
\hline
\end{tabular}


WSRC-RP-94-1227, Rev. 2 Appendix A

\begin{tabular}{|c|c|c|c|c|c|}
\hline $\begin{array}{l}\text { SRS } \\
\text { EMS } \\
\text { Desig }\end{array}$ & $\begin{array}{l}\text { Health- } \\
\text { Based } \\
\text { Limft }\end{array}$ & Units & $\begin{array}{l}\text { Common } \\
\text { Chemical Name }\end{array}$ & $\begin{array}{l}\text { CAS } \\
\text { Number }\end{array}$ & $\begin{array}{c}\text { Soures } \\
\text { of } \\
\text { HBL }\end{array}$ \\
\hline BR82 & 3150 & pCin & Bromine-82 & $014686-69-2$ & Prop. PDWS \\
\hline BRCLM & 0.048 & $\mathrm{mg} / \mathrm{L}$ & Bromochloromethane & $000074-97-5$ & Technical \\
\hline BRDCLM & 0.1 & $\mathrm{mgl}$ & Bromodichloromethane & $000075-27-4$ & PDWS \\
\hline $\mathrm{CHBR3}$ & 0.1 & $\mathrm{mgl}$ & Bromoform & $000075-25-2$ & PDWS \\
\hline $\mathrm{CD}$ & 0.005 & $m g / L$ & Cadmium & NOCASRN & PDWS \\
\hline CDDIS & 0.005 & $\mathrm{mgl}$ & Cadmium, Dissolved & NO CAS RN & PDWS \\
\hline CDTOT & 0.005 & $m g h$ & Cadmium, Total & NOCAS RN & PDWS \\
\hline CD109 & 227 & pCin & Cadmium-109 & $014109-32-1$ & Prop. PDWS \\
\hline CD115 & 958 & pCin & Cadmium-115 & $014336-68-6$ & Prop. PDWS \\
\hline CD115M & 339 & pcin & Cadmium-115m & $014336-68-6(m)$ & Prop. PDWS \\
\hline CA45 & 1730 & pCir & Calcium-45 & $013966-05-7$ & Prop. PDWS \\
\hline CA47 & 846 & pein & Calcium-47 & $001439.99-2$ & Prop. PDWS \\
\hline CF252 & 16.2 & pCir & Califomium-252 & & Prop. PDWS \\
\hline CCL4 & 0.005 & $m g h$ & Carbon Tetrachloride & $000056-23-5$ & PDWS \\
\hline CARB11. & 99200 & pCil & Carbon-11 & $014333-33-6$ & Prop. PDWS \\
\hline C14 & 3200 & pein & Carbon-14 & $014762-75-5$ & Prop. PDWS \\
\hline C15 & $6.69 E+06$ & pCin & Carbon-15 & $015929-23-4$ & Prop. PDWS \\
\hline CE141 & 1890 & pcin & Cerium-141 & $013967-74-3$ & Prop. PDWS \\
\hline CE143 & 1210 & pCin & Cerium-143 & $014119-19-8$ & Prop. PDWS \\
\hline CE144 & 261 & pcin & Cerium-144 & $014762-78-8$ & Prop. PDWS \\
\hline CE147 & 1890 & $p \operatorname{cin}$ & Cerium-147 & & Prop. PDWS \\
\hline CS131 & 22800 & pCin & Cesium-131 & $014914-76-2$ & Prop. PDWS \\
\hline CS134 & 81.3 & pCin & Cesium-134 & $013967-70-9$ & Prop. PDWS \\
\hline CS134M & $1.01 E+05$ & pCin & Cesium-134m & $013967-70-9(\mathrm{~m})$ & Prop. PDWS \\
\hline CS135 & 794 & pCin & Cesium-135 & $015726-30-4$ & Prop. PDWS \\
\hline CS136 & 518 & pCin & Cesium-136 & $014234-29-8$ & Prop. PDWS \\
\hline CS137 & 119 & pCin & Cesium-137 & $010045-97-3$ & Prop. PDWS \\
\hline CS138 & 25600 & pCin & Cesium-138 & $015758-29-9$ & Prop. PDWS \\
\hline CLDAN & 0.002 & $\mathrm{mg} / \mathrm{L}$ & Chlordane & $000057-74-9$ & PDWS \\
\hline CL36 & 1850 & $p \operatorname{cin}$ & Chlorine-36 & $013981-43-6$ & Prop. PDWS \\
\hline CL38 & 21200 & pCin & Chlorine-38 & $014158-34-0$ & Prop. PDWS \\
\hline CLC6H5 & 0.1 & $\mathrm{mgl}$ & Chlorobenzene & $000108-90-7$ & PDWS \\
\hline $\mathrm{C} 2 \mathrm{H} 5 \mathrm{CL}$ & 8.6 & $\mathrm{mgh}$ & Chloroethane & $000075-00-3$ & EPA-III PRG \\
\hline $\mathrm{CHCL3}$ & 0.1 & $\mathrm{mg} / \mathrm{L}$ & Chloroform & $000067-66-3$ & PDWS \\
\hline $\mathrm{CH} 3 \mathrm{CL}$ & 0.0014 & $m g l$ & Chloromethane & $000074-87-3$ & EPA-III PRG \\
\hline CR & 0.1 & $m g /$ & Chromium & NO CAS RN & PDWS \\
\hline CADIS & 0.1 & $m g l$ & Chromium, Dissolved & NOCAS RN & PDWS \\
\hline CRTOT & 0.1 & $m g l$ & Chromium. Total & NOCASRN & PDWS \\
\hline CR51 & 38000 & pCir & Chromium-51 & $014392-02-0$ & Prop. POWS \\
\hline C12DCE & 0.07 & $\mathrm{mgl}$ & cis-1,2-Dichloroethylene & $000156-59-2$ & PDWS \\
\hline $\mathrm{CO}$ & 2.2 & $m g / l$ & Coball & NOCAS RN & EPA-III PRG \\
\hline CODIS & 2.2 & $m g h$ & Coball, Dissolved & NOCAS RN & EPA-III PRG \\
\hline COTOT & 2.2 & $\mathrm{mgh}$ & Cobalt. Total & NO CAS RN & EPA-III PRG \\
\hline $\mathrm{CO57}$ & 4870 & pCir & Coball-57 & $013981.50-5$ & Prop. PDWS \\
\hline $\mathrm{CO58}$ & 1590 & pCin & Cobalt.58 & & Prop. PDWS \\
\hline CO58M & 64900 & pCin & Coball-58m & & Prop. PDWS \\
\hline
\end{tabular}


WSRC-RP-94-1227, Rev. 2

Appendix A

\begin{tabular}{|c|c|c|c|c|c|}
\hline $\begin{array}{l}\text { SAS } \\
\text { EMS } \\
\text { Desig }\end{array}$ & $\begin{array}{l}\text { Health- } \\
\text { Based } \\
\text { Limit }\end{array}$ & Units & $\begin{array}{l}\text { Common } \\
\text { Chemical Name }\end{array}$ & $\begin{array}{l}\text { CAS } \\
\text { Number }\end{array}$ & $\begin{array}{c}\text { Source } \\
\text { of } \\
\text { HBL }\end{array}$ \\
\hline CO60 & 218 & pCil & Cobalt -60 & $010198-40-0$ & Prop. PDWS \\
\hline $\mathrm{CU}$ & 1.3 & $m g h$ & Copper & NOCASRN & PDWS TT \\
\hline CUDIS & 1.3 & $m g h$ & Copper, Dissolved & NO CASRN & PDWST \\
\hline CUTOT & 1.3 & $m g l$ & Copper, Total & NO CAS RN & POWS T \\
\hline CU64 & 11900 & pCin & Copper-64 & $013981-25-4$ & Prop. Pows \\
\hline $\mathrm{CSOL}$ & 2 & mgll & Cresols & $001319-77-3$ & TCLP/100 \\
\hline CM242 & 133 & pCin & Curium-242 & $015510-73-3$ & Prop. PDWS \\
\hline CM243 & 8.3 & $\mathrm{pCin}$ & Curium-243 & $015757-87-6$ & Prop. PDWS \\
\hline CM4344 & 8.3 & pcin & Curium-243/244 & NO CAS RN & Prop. PDWS \\
\hline CM244 & 9.84 & pCin & Curium-244 & $013981-15-2$ & Prop. PDWS \\
\hline CM245 & 6.23 & pCin & Curium-245 & $015621-76-8$ & Prop. PDWS \\
\hline CM246 & 6.27 & pein & Curium-246 & $015757-90-1$ & Prop. PDWS \\
\hline CM247 & 6.79 & pCin & Curium-247 & $015758-32-4$ & Prop. PDWS \\
\hline CM248 & 1.67 & pCin & Curium-248 & $015758-33-5$ & Prop. PDWS \\
\hline CYN & 0.2 & $\mathrm{mgl}$ & Cyanide & $000057-12-5$ & PDWS \\
\hline $\mathrm{DCB}$ & 0.033 & ngl & Decachlorobiphenyl & $001335-36-3$ & Technical \\
\hline DNBP & 3.7 & $\mathrm{mgl}$ & Di-n-butyd Phthalate & $000084-74-2$ & EPA-III PAG \\
\hline DNOP & 0.73 & $\mathrm{mgl}$ & Di-n-octyl Phthalate & $000117-84-0$ & EPA-III PRG \\
\hline DBRCLM & 0.1 & $\mathrm{mgl}$ & Dibromochloromethane & $000124-48-1$ & PDWS \\
\hline CL2BZ & 0.6 & $m g l$ & Dichlorobenzenes & $025321-22-6$ & PDWS \\
\hline CCL2F2 & 0.39 & $\mathrm{mgh}$ & Dichlorodifluoromethane & $000075-71-8$ & EPA-III PRG \\
\hline DEP & 29 & mgll & Diethyl Phihalate & $000084-66-2$ & EPA-III PRG \\
\hline DY165 & 15100 & pCin & Dysprosium-165 & $013967-64-1$ & Prop. PDWS \\
\hline DY166 & 830 & pCin & Dysprosium-166 & $015840-01-4$ & Prop. PDWS \\
\hline ENDAN & 0.002 & $\mathrm{mg} \Omega$ & Endrin & $000072-20-8$ & PDWS \\
\hline ER169 & 3640 & $\mathrm{pCin}$ & Erbium-169 & $015840-13-8$ & Prop. PDWS \\
\hline ER171 & 3800 & pcil & Erbium-171 & $014391-45-8$ & Prop. POWS \\
\hline ETC6H5 & 0.7 & $\mathrm{mgl}$ & Ethylbenzene & $000100-41-4$ & PDWS \\
\hline EU152 & 841 & pCin & Europium-152 & $014683-23-9$ & Prop. PDWS \\
\hline EU154 & 573 & pCin & Europium-154 & $015585-10-1$ & Prop. PDWS \\
\hline EU155 & 3590 & pCin & Europium-155 & $014391-16-3$ & Prop. PDWS \\
\hline EU156 & 600 & pCin & Europium-156 & $014280-35-4$ & Prop. PDWS \\
\hline FPH & $>12$ & $\mathrm{pH}$ & Field pH & NO CAS RN & SCHWMA \\
\hline FPH & $<2$ & $\mathrm{pH}$ & Field $\mathrm{pH}$ & NO CAS AN & SCHWMR \\
\hline$F$ & 4 & $\mathrm{mg} / \mathrm{L}$ & Fivoride & $016984-48-8$ & PDWS \\
\hline F18 & 39500 & pCir & Fluorine-18 & $013981-56-1$ & Prop. PDWS \\
\hline FR221 & 32600 & $\mathrm{pCi}$ L & Francium-221 & $015756-41-9$ & Prop. PDWS \\
\hline FR223 & 3410 & pCin & Francium-223 & $015756-98-6$ & Prop. PDWS \\
\hline GD153 & 4680 & $\mathrm{pCin}$ & Gadolinium-153 & $014276-65-4$ & Prop. PDWS \\
\hline GD159 & 2760 & pCin & Gadolinium-159 & $014041-42-0$ & Prop. PDWS \\
\hline GA67 & 7020 & pCin & Gallium-67 & $014119-09-6$ & Prop. PDWS \\
\hline GA72 & 1190 & $\mathrm{pCin}$ & Gallium-72 & $013982-22-4$ & Prop. PDWS \\
\hline GE71 & $4.36 E+05$ & pCin & Germanium-71 & 014374.81 .3 & Prop. PDWS \\
\hline AU196 & 3660 & pCin & Gold-196 & $010043-49-0$ & Prop. PDWS \\
\hline AU198 & 1310 & $\mathrm{pCin}$ & Gold-198 & $014914-16-0$ & Prop. PDWS \\
\hline ALPHAG & 15 & $p \operatorname{cin}$ & Gross Alpha & NO CAS RN & PDWS \\
\hline
\end{tabular}




\begin{tabular}{|c|c|c|c|c|c|}
\hline $\begin{array}{l}\text { SRS } \\
\text { EMS } \\
\text { Desig }\end{array}$ & $\begin{array}{l}\text { Hestit- } \\
\text { Based } \\
\text { Limit }\end{array}$ & Units & $\begin{array}{l}\text { Common } \\
\text { Chemical Name }\end{array}$ & $\begin{array}{c}\text { CAS } \\
\text { Number }\end{array}$ & $\begin{array}{c}\text { Source } \\
\text { of } \\
\mathrm{HBL}\end{array}$ \\
\hline HF181 & 1170 & pCin & Halfinium-181 & & Prop. PDWS \\
\hline $\mathrm{HPCL}$ & 0.0004 & $m g / 2$ & Heptachlor & $000076-44-8$ & PDWS \\
\hline HPCLE & 0.0002 & $m g h$ & Heptachlor Epoxide & $001024-57-3$ & PDWS \\
\hline CL6BZ & 0.13 & $m g h$ & Hexachlorobenzene & $000118-74-1$ & TCLP (PQL) \\
\hline CL6BP & 0.0005 & $m g h$ & Hexachlorobiphenyl & $001335-36-3$ & PDWS \\
\hline $\mathrm{HCBD}$ & 0.005 & $\mathrm{mgl}$ & Hexachlorobutadiene & $000087-68-3$ & TCLP/100 \\
\hline CL6CP & 0.05 & $m g l$ & Hexachlorocyclopentadiene & $000077-47-4$ & POWS \\
\hline CL6ET & 0.03 & $m g /$ & Hexachloroethane & $000067-72-1$ & TCLP/100 \\
\hline HO166 & 981 & pCin & Holmium-166 & $013967-65-2$ & Prop. PDWS \\
\hline IN113M & 52400 & pCil & Indium-113m & $014885-78-0(m)$ & Prop. PDWS \\
\hline IN114 & 976000 & pein & Indium-114 & $001398-55-0$ & Prop. PDWS \\
\hline IN114M & 323 & pCin & indium-114m & $001398-55-0(\mathrm{~m})$ & Prop. POWS \\
\hline IN115 & 35.1 & pCin & Indium-115 & $014191-71-0$ & Prop. PDWS \\
\hline IN115M & 16400 & pCill & Indium-115m & $014191-71-0(\mathrm{~m})$ & Prop. PDWS \\
\hline 1122 & $2.11 E+05$ & pCin & lodine-122 & $018287-75-7$ & Prop. PDWS \\
\hline 1123 & 10700 & pCin & lodine-123 & $015715-08-9$ & Prop. PDWS \\
\hline 1125 & 151 & pCin & lodine-125 & $014158-31-7$ & Prop. PDWS \\
\hline 1126 & 81 & pCin & lodine-126 & $014158-32-8$ & Prop. PDWS \\
\hline 1129 & 21 & $p C i n$ & lodine-129 & $015046-84-1$ & Prop. PDWS \\
\hline 1130 & 1190 & pCin & lodine-130 & $014914-02-4$ & Prop. PDWS \\
\hline 1131 & 108 & pcin & lodine-131 & $010043-66-0$ & Prop. PDWS \\
\hline 1132 & 8190 & pCill & lodine-132 & $014683-16-0$ & Prop. PDWS \\
\hline 1133 & 549 & pcin & lodine-133 & $014834-67-4$ & Prop. PDWS \\
\hline 1134 & 21400 & pCin & lodine-134 & $014914-27-3$ & Prop. PDWS \\
\hline 1135 & 2340 & pCin & lodine-135 & $014834-68-5$ & Prop. PDWS \\
\hline IR190 & 1010 & pcin & Iridium-190 & 014981.91 .0 & Prop. PDWS \\
\hline IR192 & 957 & pCin & |lridium-192 & $014694-69-0$ & Prop. PDWS \\
\hline IR194 & 1040 & $\mathrm{pCin}$ & Iridium-194 & $014158-35-1$ & Prop. PDWS \\
\hline FE55 & 9250 & pCin & Tiron-55 & $014681-59-5$ & Prop. PDWS \\
\hline FE59 & 844 & pCin & IIron-59 & $014596-12-4$ & Prop. PDWS \\
\hline ISSBAL & 1.8 & $m g h$ & Isobutyl Alcohol & $000078-83-1$ & EPA-III PRG \\
\hline ISODR & 0.083 & $\mathrm{mg} /$ & Iisodrin & $000465-73-6$ & Technical \\
\hline ISOPHA & 0.071 & $m g l$ & Isophorone & $000078-59-1$ & EPA-III PRG \\
\hline ISAFRO & 1 & $\mathrm{mgl}$ & Isosatrole & $000120-58-1$ & Technical \\
\hline LA140 & 652 & $p \operatorname{cin}$ & Lanthanum-140 & $013981-28-7$ & Prop. PDWS \\
\hline$P B$ & 0.05 & $m g h$ & Lead & NO CAS RN & SCHWMR \\
\hline PBDIS & 0.05 & $m g h$ & Lead. Dissolved & NO CAS RN & SCHWMR \\
\hline PBTOT & 0.05 & $m g l$ & Lead. Total & NO CAS RN & SCHWMR \\
\hline PB203 & 5060 & pCil & Lead-203 & $014687-25-3$ & Prop. PDWS \\
\hline PB209 & 25300 & pCin & Lead-209 & $014119-30-3$ & Prop. PDWS \\
\hline PB210 & 1.01 & $\mathrm{pCi}$ & Lead-210 & $014255-04-0$ & Prop. PDWS \\
\hline PB211 & 12800 & pcin & Lead-211 & $015816-77-0$ & Prop. PDWS \\
\hline PB212 & 123 & pcin & Lead-212 & $015092.94-1$ & Prop. PDWS \\
\hline PB214 & 11800 & pCin & Lead-214 & $015067-28-4$ & Prop. PDWS \\
\hline LIN & 0.0002 & $\mathrm{mg} / \mathrm{L}$ & Lindane & $000058-89-9$ & POWS \\
\hline LU177 & 2550 & pcin & Lutetium-177 & $014265-75-9$ & Prop. PDWS \\
\hline
\end{tabular}




\begin{tabular}{|c|c|c|c|c|c|}
\hline $\begin{array}{l}\text { SRS } \\
\text { EMS } \\
\text { Desig }\end{array}$ & $\begin{array}{l}\text { Heath- } \\
\text { Based } \\
\text { Limit }\end{array}$ & Units & $\begin{array}{l}\text { Common } \\
\text { Chemical Name }\end{array}$ & $\begin{array}{l}\text { CAS } \\
\text { Number }\end{array}$ & $\begin{array}{c}\text { Source } \\
\text { of } \\
\text { HBL }\end{array}$ \\
\hline MCRES & 2 & $m g h$ & m-Cresol & $000108-39-4$ & TCLP/100 \\
\hline MN52 & 733 & pCin & Manganese-52 & $014092-99-0$ & Prop. PDWS \\
\hline MN54 & 2010 & pCir & Manganese-54 & $013966-31-9$ & Prop. PDWS \\
\hline MN56 & 5640 & pCin & Manganese-56 & $014681-52-8$ & Prop. PDWS \\
\hline HG & 0.002 & $\mathrm{mgl}$ & Mercury & NO CAS RN & PDWS \\
\hline HGDIS & 0.002 & mgh & Mercury. Dissolved & NO CAS RN & PDWS \\
\hline HGTOT & 0.002 & $\mathrm{mgl}$ & Mercury, Total & NOCAS AN & PDWS \\
\hline HG197 & 5760 & pCin & Mercury-197 & $013981.51-6$ & Prop. PDWS \\
\hline HG203 & 2390 & pCin & Mercury-203 & $013982-78-0$ & Prop. PDWS \\
\hline MEXCLR & 0.04 & $\mathrm{mgl}$ & Methoxychlor & $000072-43-5$ & PDWS \\
\hline $\mathrm{CH}_{2} \mathrm{CL}_{2}$ & 0.005 & mgl & Methylene Chloride & $000075-09-2$ & PDWS \\
\hline MEK & 2 & $\mathrm{mgl}$ & Methylethyl Ketone & $000078-93-3$ & TCLP/100 \\
\hline 4ME2PE & 2.9 & $m g / L$ & Methylisobutyl Ketone & $000108-10-1$ & EPA-III PRG \\
\hline MIBK & 2.9 & $\mathrm{mgl}$ & Methylisobuty Ketone & $000108-10-1$ & EPA-III PRG \\
\hline MO99 & 1830 & pCin & Molybdenum-99 & $014119-15-4$ & Prop. PDWS \\
\hline NDNBA & 0.012 & $\mathrm{mgl}$ & N-Nitrosodi-N-Butylamine & $000924-16-3$ & EPA-III PAG \\
\hline NDNPA & 0.0096 & $\mathrm{mgl}$ & $\mathrm{N}$-Nitrosodi-N-Propylamine & $000621-647$ & EPA-III PAG \\
\hline NETA & 0.00045 & mgl & N-Nitrosodiethylamine & $000055-18-5$ & EPA-III PRG \\
\hline NDMA & 0.0013 & $\mathrm{mgl}$ & N-Nitrosodimethylamine & $000062-75-9$ & EPA-III PRG \\
\hline NETMEA & 0.1 & $\mathrm{mgl}$ & N-Nitrosoethyimethyiamine & $010595-95-6$ & EPA-III PRG \\
\hline NAP & 1.5 & $m g l$ & Naphthalene & $000091-20-3$ & EPA-III PRG \\
\hline ND147 & 1250 & pCin & Neodymium-147 & $014269-74-0$ & Prop. PDWS \\
\hline ND149 & 11700 & pCin & Neodymium-149 & $015759-81-2$ & Prop. PDWS \\
\hline NP236 & 5960 & pcin & Neptunium-236 & $015700-36-4$ & Prop. PDWS \\
\hline NP237 & 7.06 & pcin & Neptunium-237 & $013994-20-2$ & Prop. PDWS \\
\hline NP238 & 1390 & pCin & Neptunium-238 & $015766-25-3$ & Prop. POWS \\
\hline NP239 & 1680 & $\mathrm{pCi} \Omega$ & Neptunium-239 & $013968-59-7$ & Prop. PDWS \\
\hline NP240 & 23100 & $p \mathrm{Ci} / \mathrm{L}$ & Neplunium-240 & $015690-84-3$ & Prop. PDWS \\
\hline NP240M & $1.74 E+05$ & pCin & Neptunium-240m & $015690-84-3(\mathrm{~m})$ & Prop. PDWS \\
\hline $\mathrm{NI}$ & 0.1 & $\mathrm{mg} / \mathrm{L}$ & Nickel & NO CAS RN & PDWS \\
\hline NIDIS & 0.1 & $\mathrm{mgl}$ & Nickel, Dissolved & NO CAS RN & PDWS \\
\hline NITOT & 0.1 & $m g / 2$ & Nickel, Total & NO CAS RN & POWS \\
\hline N159 & 27000 & pcin & Nickel-59 & $014336-70-0$ & Prop. POWS \\
\hline N163 & 9910 & pCin & Nickel-63 & $013981-37-8$ & Prop. PDWS \\
\hline N165 & 8810 & $\mathrm{pCi}$ & Nickel-65 & $014833-49-9$ & Prop. PDWS \\
\hline NB93M & 10500 & pCir & Niobium-93m & $007440-03-1(\mathrm{~m})$ & Prop. PDWS \\
\hline NB94 & 707 & pCin & Niobium-94 & $014681-63-1$ & Prop. PDWS \\
\hline NB95 & 2150 & $\mathrm{pCin}$ & Niobium-95 & $013967-76-5$ & Prop. PDWS \\
\hline NB95M & 2390 & pCin & Niobium-95m & $013967-76-5(\mathrm{~m})$ & Prop. PDWS \\
\hline NB97 & 23500 & pCin & Niobium-97 & $018496-04-3$ & Prop. PDWS \\
\hline NB97M & $1.37 E+06$ & pcin & Niobium-97m & $018496-04-3(m)$ & Prop. PDWS \\
\hline $\mathrm{NO3}$ & 10 & $\mathrm{mg} / \mathrm{L}$ & Nitrate as Nitrogen & $014797-55-8$ & PDWS \\
\hline NO3NO2 & 10 & $\mathrm{mg} / \mathrm{L}$ & Nitrite + Nitrate as Nitrogen & NO CAS RN & PDWS \\
\hline NO2 & 1 & mgl & Nitrite as Nitrogen & $014797-65-0$ & POWS \\
\hline NB & 0.02 & $\mathrm{mg} / \mathrm{L}$ & Nitrobenzene & $000098-95-3$ & TCLP/100 \\
\hline $\mathrm{N13}$ & $1.52 E+05$ & pCin & Nitrogen-13 & & Prop. POWS \\
\hline
\end{tabular}


WSRC-RP-94-1227, Rev. 2 Appendix A

\begin{tabular}{|c|c|c|c|c|c|}
\hline $\begin{array}{l}\text { SRS } \\
\text { EMS } \\
\text { Desig }\end{array}$ & $\begin{array}{l}\text { Health- } \\
\text { Based } \\
\text { Limit }\end{array}$ & Units & $\begin{array}{l}\text { Common } \\
\text { Chemical Name }\end{array}$ & $\begin{array}{c}\text { CAS } \\
\text { Number }\end{array}$ & $\begin{array}{c}\text { Source } \\
\text { of } \\
\text { HBL }\end{array}$ \\
\hline BETAG & 50 & pCin & Nonvolatile Beta & NOCAS RN & Est. PDWS \\
\hline OCRES & 2 & $\mathrm{mg} h$ & o-Cresol & $000095-48-7$ & TCLP/100 \\
\hline 05185 & 2460 & pcin & Osmium-185 & $015766-50-4$ & Prop. PDWS \\
\hline OS191 & 2380 & pCin & Osmium-191 & $014119-24-5$ & Prop. PDWS \\
\hline OS191M & 14300 & pCin & Osmium-191m & $014119-24-5(m)$ & Prop. PDWS \\
\hline OS193 & 1690 & pCin & Osmium-193 & $016057-77-5$ & Prop. PDWS \\
\hline 015 & $4.95 E+05$ & pCin & Oxygen-15 & & Prop. PDWS \\
\hline PBFB & 0.06 & $m g / 2$ & P-bromofluorobenzene & & Technieal \\
\hline PCRES & 2 & $\mathrm{mg} / \mathrm{L}$ & p-Cresol & $000106-44-5$ & TCLP/100 \\
\hline PD100 & 1300 & pcin & Palladium-100 & $015690-69-4$ & Prop. PDWS \\
\hline PD101 & 13400 & pCin & Palladium-101 & $015749-54-9$ & Prop. PDWS \\
\hline PD103 & 6940 & pCin & Palladium-103 & $014967-68-1$ & Prop. PDWS \\
\hline PD107 & 36600 & pCin & Palladium-107 & $017637-99-9$ & Prop. PDWS \\
\hline PD109 & 2120 & pcin & Palladium-109 & $014981-647$ & Prop. PDWS \\
\hline PCB016 & 0.0005 & $\mathrm{mgl}$ & PCB 1016 & $012674-11-2$ & PDWS \\
\hline PCB221 & 0.0005 & $\mathrm{mg} / \mathrm{l}$ & PCB 1221 & $011104-28-2$ & PDWS \\
\hline PCB232 & 0.0005 & $\mathrm{mg} / \mathrm{L}$ & PCB 1232 & $011141-16-5$ & PDWS \\
\hline PCB242 & 0.0005 & $\mathrm{mgh}$ & PCB 1242 & $053469-21-9$ & PDWS \\
\hline PCB248 & 0.0005 & $\mathrm{mg} / \mathrm{L}$ & PCB 1248 & $012672-29-6$ & PDWS \\
\hline PCB254 & 0.0005 & mgl & PCB 1254 & $011097-69-1$ & PDWS \\
\hline PCB260 & 0.0005 & $\mathrm{mg} / \mathrm{L}$ & PCB 1260 & $011096-82-5$ & PDWS \\
\hline PCB262 & 0.0005 & $\mathrm{mg} / \mathrm{L}$ & PCB 1262 & $001335-36-3$ & PDWS \\
\hline CL5BP & 0.0005 & mgl & Pentachlorobiphenyl & $001335-36-3$ & PDWS \\
\hline PCP & 0.001 & $\mathrm{mgl}$ & Pentachlorophenol & $000087-86-5$ & PDWS \\
\hline PHENOL & 22 & $\mathrm{mgh}$ & Phenol & $000108-95-2$ & EPA-III PAG \\
\hline P32 & 641 & pCin & Phosphorus-32 & $014596-37-3$ & Prop. PDWS \\
\hline P33 & 1870 & pCin & Phosphorus-33 & $015749-66-3$ & Prop. PDWS \\
\hline PT191 & 3810 & pCin & Platinum-191 & $015706-36-2$ & Prop. PDWS \\
\hline PT193 & 46100 & pCin & Platinum-193 & $015735-70-3$ & Prop. POWS \\
\hline PT193M & 3020 & $\mathrm{pCin}$ & Platinum-193m & $015735-70-3(\mathrm{~m})$ & Prop. PDWS \\
\hline PT197 & 3400 & pCin & Platinum-197 & $015735-74-7$ & Prop. PDWS \\
\hline PT197M & 17500 & pCir & Platinum-197m & $015735-74-7(m)$ & Prop. PDWS \\
\hline PU236 & 32.3 & pCir & Plutonium-236 & $015411-92-4$ & Prop. PDWS \\
\hline PU238 & 7.02 & $\mathrm{pCin}$ & Plutonium-238 & $013981-16-3$ & Prop. PDWS \\
\hline PU3839 & 40 & $\mathrm{pCin}$ & Plutonium-238/239 & NO CAS RN & Prop. PDWS \\
\hline PU239 & 62.1 & pcin & Plutonium-239 & $015117-48-3$ & Prop. PDWS \\
\hline PU3940 & 62.1 & pcin & Plutonium-239/240 & NO CAS RN & Prop. PDWS \\
\hline PU240 & 62.2 & pCin & Plutonium-240 & $014119-33-6$ & Prop. PDWS \\
\hline PU241 & 62.6 & $p \operatorname{cin}$ & Plutonium-241 & $014119-32-5$ & Prop. PDWS \\
\hline PU242 & 65.4 & pCin & Plutonium-242 & $013982-10-0$ & Prop. PDWS \\
\hline PU243 & 16400 & pCin & Plutonium-243 & $015706-37-3$ & Prop. PDWS \\
\hline$\longdiv { \text { PU244 } }$ & 6.87 & pCin & Plutonium-244 & $014119-34-7$ & Prop. PDWS \\
\hline PO210 & 7.46 & pCin & Polonium-210 & $013981-52-7$ & Prop. PDWS \\
\hline PO212 & $8.78 E+13$ & pCin & Polonium-212 & $015389-34-1$ & Prop. PDWS \\
\hline PO213 & $6.06 E+12$ & pCill & Polonium-213 & $015756-57-7$ & Prop. PDWS \\
\hline PO214 & $1.86 E+11$ & pCill & Polonium-214 & $015735-67-8$ & Prop. PDWS \\
\hline
\end{tabular}




\begin{tabular}{|c|c|c|c|c|c|}
\hline $\begin{array}{l}\text { SRS } \\
\text { EMS } \\
\text { Desig } \\
\end{array}$ & $\begin{array}{l}\text { Heafth- } \\
\text { Based } \\
\text { Limlt }\end{array}$ & Units & $\begin{array}{l}\text { Common } \\
\text { Chemical Name }\end{array}$ & $\begin{array}{c}\text { CAS } \\
\text { Number }\end{array}$ & $\begin{array}{c}\text { Souree } \\
\text { of } \\
\text { HBL }\end{array}$ \\
\hline P0215 & $6.84 E+09$ & pcin & Polonium-215 & $015706-52-2$ & Prop. PDWS \\
\hline PO216 & $5.30 E+07$ & pcin & Polonium-216 & $015756-58-8$ & Prop. PDWS \\
\hline PO218 & 69100 & pCill & Polonium-218 & $015422-24-9$ & Prop. PDWS \\
\hline $\mathrm{K} 40$ & 300 & pCin & Potassium- 40 & $013966-00-2$ & Prop. PDWS \\
\hline $\mathrm{K} 42$ & 3900 & pCil & Potassium-42 & $014378-21-3$ & Prop. PDWS \\
\hline PR142 & 1040 & pCir & Praseodymium-142 & $014191-64-1$ & Prop. PDWS \\
\hline PR143 & 1170 & pCin & Praseodymium-143 & $014981-79-4$ & Prop. PDWS \\
\hline PR144 & 47000 & pCin & Praseodymium-144 & $014119-05-2$ & Prop. PDWS \\
\hline PA144M & $1.12 E+05$ & pCin & Praseodymium-144m & $014119-05-2(m)$ & Prop. PDWS \\
\hline PM147 & 5240 & pein & Promethium-147 & $014380-75-7$ & Prop. PDWS \\
\hline PM148 & 505 & $\mathrm{pCin}$ & Promethium-148 & $014683-19-3$ & Prop. PDWS \\
\hline PM148M & 575 & pCil & Promethium-148m & $014683-19 \cdot 3(\mathrm{~m})$ & Prop. PDWS \\
\hline PM149 & 1380 & pCil & Promethium-149 & $015765-31-8$ & Prop. PDWS \\
\hline PA231 & 10.2 & pCir & Protactinium-231 & $014331-85-2$ & Prop. PDWS \\
\hline PA233 & 1510 & pCin & Protactinium-233 & $013981-14-1$ & Prop. PDWS \\
\hline PA234 & 2560 & pCin & Protactinium-234 & $015100-28-4$ & Prop. PDWS \\
\hline PA234M & $9.30 E+05$ & pCin & Protactinium-234m & $015100-28-4(m)$ & Prop. PDWS \\
\hline PYRID & 5 & $m g l$ & Pyridine & $000110-86-1$ & TCLP (PQL) \\
\hline RA223 & 24.1 & pCin & Radium-223 & $015623-45-7$ & Prop. PDWS \\
\hline RA224 & 40.6 & pCin & Radium-224 & $013233-32-4$ & Prop. PDWS \\
\hline RA225 & 9.14 & $\mathrm{pCil}$ & Radium-225 & $013981-53-8$ & \begin{tabular}{|l|} 
Prop. PDWS \\
\end{tabular} \\
\hline RA226 & 20 & PCil & Radium-226 & $013982-63-3$ & Prop. PDWS \\
\hline RA228 & 20 & pCir & Radium-228 & $015262-20-1$ & Prop. PDWS \\
\hline RN222 & 300 & $\mathrm{pCin}$ & Radon-222 & $014859-67-7$ & Prop. PDWS \\
\hline RE183 & 5400 & $\mathrm{pCin}$ & Rhenium-183 & & Prop. PDWS \\
\hline RE186 & 1880 & pCin & Rhenium-186 & & Prop. PDWS \\
\hline RE187 & $5.82 E+05$ & pin & Rhenium-187 & & Prop. PDWS \\
\hline RE188 & 1790 & p Cir & Rhenium-188 & & Prop. PDWS \\
\hline RH103M & $4.71 E+05$ & $\mathrm{pCin}$ & Rhodium-103m & $007440-16-6(\mathrm{~m})$ & Prop. PDWS \\
\hline RH105 & 3720 & pCil & Rhodium-105 & $014913-89-4$ & Prop. PDWS \\
\hline RH105M & $5.51 E+06$ & pCil & Rhodium-105m & $014913-89-4(\mathrm{~m})$ & Prop. PDWS \\
\hline RH106 & $1.24 E+06$ & $\mathrm{pCi}$ & Rhodium-106 & $013967-48-1$ & Prop. PDWS \\
\hline RB82 & $4.36 E+05$ & $\mathrm{pCin}$ & Rubidium-82 & $014391-63-0$ & Prop. PDWS \\
\hline RB86 & 485 & $\mathrm{pCin}$ & Rubidium-86 & $014932-53-7$ & Prop. PDWS \\
\hline RB87 & 501 & $\mathrm{pCi}$ & Rubidium-87 & $013982-13-3$ & Prop. PDWS \\
\hline AB88 & 29100 & $\mathrm{pCin}$ & Rubidium-88 & $014928-36-0$ & Prop PDWS \\
\hline RB89 & 52700 & $\mathrm{pCin}$ & Pubidium-89 & $014191-65-2$ & Prop. PDWS \\
\hline RU103 & 1810 & pCin & Ruthenium-103 & $013968-53-1$ & Prop. PDWS \\
\hline RU105 & 4990 & $\mathrm{pCi} /$ & Ruthenium-105 & $014331-95-4$ & Prop. PDWS \\
\hline RU106 & 203 & pCill & Ruthenium-106 & $013967-48-1$ & Prop. PDWS \\
\hline RU97 & 7960 & $\mathrm{pCi}$ & Ruthenium-97 & $015758-35-7$ & Prop. PDWS \\
\hline SAFROL & 1 & $\mathrm{mgl}$ & Safrole & $000094-59-7$ & Technical \\
\hline SM147 & 104 & pCin & Samarium-147 & $014392-33-7$ & Prop. POWS \\
\hline SM151 & 14100 & pCin & Samarium-151 & $015715-94-3$ & Prop. PDWS \\
\hline SM153 & 1830 & $\mathrm{pCi} / \mathrm{L}$ & Samarium-153 & $015766-00-4$ & Prop. PDWS \\
\hline SC46 & 863 & p Cin & Scandium-46 & $013967.63-0$ & Prop. PDWS \\
\hline
\end{tabular}


WSRC-RP-94-1227, Rev. 2 Appendix A

\begin{tabular}{|c|c|c|c|c|c|}
\hline $\begin{array}{l}\text { SRS } \\
\text { EMS } \\
\text { Deaig }\end{array}$ & $\begin{array}{l}\text { Heafth- } \\
\text { Based } \\
\text { Limit }\end{array}$ & Units & $\begin{array}{l}\text { Common } \\
\text { Chemical Name }\end{array}$ & $\begin{array}{c}\text { CAS } \\
\text { Number }\end{array}$ & $\begin{array}{c}\text { Source } \\
\text { of } \\
\text { HBL }\end{array}$ \\
\hline SC47 & 2440 & pCin & Scandium-47 & $014391.96-9$ & Prop. PDWS \\
\hline SC48 & 766 & pCil & Scandium-48 & $014391-86-7$ & Prop. PDWS \\
\hline SE & 0.05 & $\mathrm{mgh}$ & Selenium & NOCAS RN & PDWS \\
\hline SEDIS & 0.05 & $\mathrm{mgh}$ & Selenium, Dissolved & NO CAS RN & PDWS \\
\hline SETOT & 0.05 & mgl & Selenium, Total & NOCAS RN & PDWS \\
\hline SE75 & 574 & pCin & Selenium-75 & $014265-71-5$ & Prop. PDWS \\
\hline S131 & 10200 & pCin & Silicon-31 & $014276-49-4$ & Prop. PDWS \\
\hline$A G$ & 0.18 & $\mathrm{mgh}$ & Silver & NOCAS AN & EPA-III PRG \\
\hline AGDIS & 0.18 & $m g h$ & Silver, Dissolved & NO CAS RN & EPA-III PRG \\
\hline AGTOT & 0.18 & $\mathrm{mgl}$ & Silver, Total & NOCAS RN & EPA-III PAG \\
\hline AG105 & 2700 & PCin & Silver-105 & $014928-14-4$ & Prop. PDWS \\
\hline AG108 & $6.26 E+05$ & pCin & Silver-108 & $014391-65-2$ & Prop. PDWS \\
\hline AG108M & 723 & $\mathrm{pCi}$ & Silver-108m & $014391-65-2(m)$ & Prop. PDWS \\
\hline AG109M & $1.67 E+07$ & $\mathrm{pCin}$ & Silver-109m & $014378-38-2(\mathrm{~m})$ & Prop. PDWS \\
\hline AG110 & $1.84 E+06$ & $\mathrm{pCi}$ & Silver-110 & $014391-76-5$ & Prop. PDWS \\
\hline AG110M & 512 & pCin & Silver-110m & $014391-76-5(m)$ & Prop. POWS \\
\hline AG111 & 1080 & pCil & Silver-111 & $015769-040$ & Prop. PDWS \\
\hline SILVEX & 0.05 & mgl & Silvex & $000093-72-1$ & PDWS \\
\hline NA22 & 466 & $\mathrm{pCi}$ & Sodium-22 & $013966-32-0$ & Prop. PDWS \\
\hline NA24 & 3350 & $\mathrm{pCin}$ & Sodium-24 & $013982-04-2$ & Prop. PDWS \\
\hline SR82 & 241 & pCin & Strontium-82 & $014809-50-8$ & Prop. PDWS \\
\hline SR85 & 2830 & pCin & Strontium-85 & $013967-73-2$ & Prop. PDWS \\
\hline SA85M & $2.37 E+05$ & pCin & Strontium-85m & $013967-73-2(\mathrm{~m})$ & Prop. PDWS \\
\hline SR89 & 599 & pCil & Strontium-89 & $014158-27-1$ & Prop. PDWS \\
\hline SR90 & 8 & $\mathrm{pCin}$ & Strontium-90 & $010098-97-2$ & Int. PDWS \\
\hline SR91 & 2160 & pCin & Strontium-91 & $014331-91-0$ & Prop. PDWS \\
\hline SR92 & 3100 & pCin & Strontium-92 & $014928-29-1$ & Prop. PDWS \\
\hline STYR & 0.1 & $\mathrm{mg} / \mathrm{L}$ & Styrene & $000100-42-5$ & PDWS \\
\hline $5 \mathrm{SO}_{4}$ & 500 & $\mathrm{mg} / \mathrm{L}$ & Sulfate & $014808-79-8$ & Def. PDWS \\
\hline S35 & 12900 & pCin & Sulfur-35 & $015117-53-0$ & Prop. PDWS \\
\hline TA182 & 842 & pCir & Tantalum-182 & $013982-00-8$ & Prop. PDWS \\
\hline TC95 & 69700 & $p \mathrm{Cin}$ & Technetium-95 & $014809-56-4$ & Prop. PDWS \\
\hline TC95M & 3120 & pCin & Technetium-95m & $014809-56-4(\mathrm{~m})$ & Prop. PDWS \\
\hline TC96 & 2050 & pCin & Technetium-96 & $014808-44-7$ & Prop. PDWS \\
\hline TC96M & $1.76 E+05$ & pCin & Technetium-96m & $014808-44.7(\mathrm{~m})$ & Prop. PDWS \\
\hline TC97 & 32500 & pCin & Technetium-97 & $015759-35-0$ & Prop. PDWS \\
\hline TC97M & 4450 & pCin & Technetium-97m & $015759-35-0(m)$ & Prop. PDWS \\
\hline TC99 & 3790 & pCin & Technetium-99 & $014133-76-7$ & Prop. PDWS \\
\hline TC99M & 89600 & pCin & Technetium-99m & $014133-76-7(\mathrm{~m})$ & Prop. PDWS \\
\hline TE125M & 1490 & pCin & Tellunium-125m & $014390-73-9(\mathrm{~m})$ & Prop. PDWS \\
\hline TE127 & 7920 & pein & Tellunium-127 & $013980-49-2$ & Prop. PDWS \\
\hline TE127M & 663 & pCin & Tellurium-127m & $013980-49 \cdot 2(\mathrm{~m})$ & Prop. PDWS \\
\hline TE129 & 27200 & pCin & Tellurium-129 & $014269-71-7$ & Prop. PDWS \\
\hline TE129M & 524 & pCin & Tellunium-129m & $014269-71.7(\mathrm{~m})$ & Prop. PDWS \\
\hline TE131 & 26800 & pcin & Tellurium-131 & $014683-12-6$ & Prop. PDWS \\
\hline TE131M & 971 & pcin & Tellurium-131m & $014683-12-6(\mathrm{~m})$ & Prop. PDWS \\
\hline
\end{tabular}


WSRC-RP-94-1227, Rev. 2 Appendix A

\begin{tabular}{|c|c|c|c|c|c|}
\hline $\begin{array}{l}\text { SRS } \\
\text { EMS } \\
\text { Desig } \\
\end{array}$ & $\begin{array}{l}\text { Health- } \\
\text { Based } \\
\text { Limit }\end{array}$ & Units & $\begin{array}{l}\text { Common } \\
\text { Chemical Name }\end{array}$ & $\begin{array}{c}\text { CAS } \\
\text { Number }\end{array}$ & $\begin{array}{c}\text { Source } \\
\text { of } \\
\text { HBL }\end{array}$ \\
\hline TE132 & 580 & pCin & Tellurium-132 & $014234-28-7$ & Prop. PDWS \\
\hline TB158 & 1250 & pCin & Terbium-158 & $015759-55-4$ & Prop. PDWS \\
\hline TB160 & 815 & peir & Terbium-160 & $013981-29-8$ & Prop. PDWS \\
\hline CL4BP & 0.0005 & $m g /$ & Tetrachlorobiphenyl & $001335-36-3$ & PDWS \\
\hline TCLEE & 0.005 & $\mathrm{mgl}$ & Tetrachloroethylene & $000127-18-4$ & PDWS \\
\hline TCX & 0.025 & $\mathrm{mg} / \mathrm{L}$ & Tetrachloroxylene & & Technical \\
\hline $\mathbf{T L}$ & 0.002 & $\mathrm{mg} / \mathrm{L}$ & Thallium & NOCAS RN & PDWS \\
\hline TLDIS & 0.002 & $\mathrm{mal}$ & Thallium, Dissolved & NOCASRN & PDWS \\
\hline TLTOT & 0.002 & $m g /$ & Thallium. Total & NO CAS RN & PDWS \\
\hline TL202 & 3840 & pCin & Thallium-202 & $015720-57-7$ & Prop. PDWS \\
\hline TL204 & 1680 & pCin & Thallium-204 & $013968-51-9$ & Prop. PDWS \\
\hline TL207 & $4.00 E+05$ & pcin & Thallium-207 & $014133-67-6$ & Prop. PDWS \\
\hline TL208 & $2.83 E+05$ & pCin & Thallium-208 & $014913-50-9$ & Prop. PDWS \\
\hline TL209 & $3.58 E+05$ & pcin & Thallium-209 & $015690-73-0$ & Prop. PDWS \\
\hline TH227 & 403 & peil & Thorium-227 & $015623-47-9$ & Prop. PDWS \\
\hline TH228 & 125 & pCin & Thorium-228 & $014274-82-9$ & Prop. PDWS \\
\hline TH229 & 49.3 & pCin & Thorium-229 & $015594-54-4$ & Prop. PDWS \\
\hline TH230 & 79.2 & pCin & Thorium-230 & $014269-63-7$ & Prop. PDWS \\
\hline TH231 & 4070 & pCir & Thorium-231 & $014932-40-2$ & Prop. PDWS \\
\hline TH232 & 88 & pCin & Thorium-232 & $007440-29-1$ & Prop. PDWS \\
\hline TH234 & 401 & pCin & Thorium-234 & $015065-10-8$ & Prop. PDWS \\
\hline TM170 & 1030 & pCin & Thulium-170 & $013981-30-1$ & Prop. PDWS \\
\hline TM171 & 12700 & pCin & Thulium-171 & $014333-45-0$ & Prop. PDWS \\
\hline SN & 22 & $\mathrm{mg} /$ & Tin & NA & EPA-III PRG \\
\hline SNDIS & $\overline{22}$ & $\mathrm{mg} / \mathrm{h}$ & Tin, Dissolved & NA & EPA-III PRG \\
\hline SNTOT & 22 & $\mathrm{mgh}$ & Tin, Total & N/A & EPA-III PRG \\
\hline SN113 & 1740 & pCin & Tin-113 & $013966-06-8$ & Prop. PDWS \\
\hline SN121 & 6060 & pCir & $T i n-121$ & $014683-06-8$ & Prop. PDWS \\
\hline SN121M & 2260 & $\mathrm{pCi}$ & Tin-121m & $014683-06-8(\mathrm{~m})$ & Prop. PDWS \\
\hline SN125 & 446 & pCir & $\operatorname{Tin}-125$ & $014683-08-0$ & Prop. PDWS \\
\hline SN126 & 293 & $\mathrm{pCi}$ & $\operatorname{Tin}-126$ & $015832-50-5$ & Prop. PDWS \\
\hline MEC6H5 & $T$ & $\mathrm{mgl}$ & Toluene & $000108-88-3$ & PDWS \\
\hline TOTRAD & 5 & pcin & Total Radium & $007440-14-4$ & PDWS \\
\hline TXPHEN & 0.003 & $\mathrm{mgh}$ & Toxaphene & $008001-35-2$ & PDWS \\
\hline TBP & 0.078 & $\mathrm{mgl}$ & Tributyl Phosphate & $000126-73-8$ & Technieal \\
\hline TRCLE & 0.005 & $\mathrm{mgh}$ & Trichloroethylene & $000079-01-6$ & PDWS \\
\hline CCL3F & 1.3 & $\mathrm{mgl}$ & Trichlorofluoromethane & $000075-69-4$ & EPA-III PRG \\
\hline TRITIU & 20 & $\mathrm{pCi} / \mathrm{mL}$ & Tritium & $010028-17-8$ & Int. POWS \\
\hline W181 & 19000 & $p C i \Omega$ & Tungsten-181 & $015749-46-9$ & Prop. PDWS \\
\hline W185 & 3440 & pCin & Tungsten-185 & $014932-41.3$ & Prop. PDWS \\
\hline W187 & 2660 & pCil & Tungsten-187 & $014983-48-3$ & Prop. PDWS \\
\hline $\bar{U}$ & 0.02 & $\mathrm{mgh}$ & Uranium & NOCAS RN & Prop. PDWS \\
\hline UAA & 1.5 & pCin & Uranium (Curies) & NO CAS RN & Technical \\
\hline UDIS & 0.02 & $\mathrm{mgh}$ & Uranium, Dissolved & NOCAS RN & Prop. PDWS \\
\hline UTOT & 0.02 & $\mathrm{mgl}$ & Uranium. Total & NO CAS RN & Prop. PDWS \\
\hline U232 & 5.72 & pCin & Uranium-232 & $014158-29-3$ & Prop. PDWS \\
\hline
\end{tabular}


WSRC-RP-94-1227, Rev. 2

Appendix A

\begin{tabular}{|c|c|c|c|c|c|}
\hline $\begin{array}{l}\text { SRS } \\
\text { EMS } \\
\text { Desig }\end{array}$ & $\begin{array}{l}\text { Health- } \\
\text { Based } \\
\text { Limh }\end{array}$ & Units & $\begin{array}{l}\text { Common } \\
\text { Chemical Name }\end{array}$ & $\begin{array}{c}\text { CAS } \\
\text { Number }\end{array}$ & $\begin{array}{c}\text { Soures } \\
\text { of } \\
\text { HBL }\end{array}$ \\
\hline U233 & 13.8 & $\mathrm{pCin}$ & Uranium-233 & $013968-55-3$ & Prop. PDWS \\
\hline U3334 & 13.8 & $\mathrm{pCi} /$ & Uranium-233/234 & NOCAS AN & Prop. PDWS \\
\hline U234 & 13.9 & pCin & Uranium-234 & $013966-29-5$ & Prop. PDWS \\
\hline U235 & 14.5 & $\mathrm{pCi}$ & Uranium-235 & $015117-96-1$ & Prop. PDWS \\
\hline U236 & 14.5 & pCin & Uranium-236 & $013982-70-2$ & Prop. PDWS \\
\hline U237 & 1780 & pCin & Uranium-237 & $014269-75-1$ & Prop. PDWS \\
\hline U238 & 14.6 & pCin & Uranium-238 & $007440-61-1$ & Prop. PDWS \\
\hline U240 & 1540 & $\mathrm{pCi}$ & Uranium-240 & $015687-53-3$ & Prop. PDWS \\
\hline$v$ & 0.26 & $\mathrm{mgl}$ & Vanadium & NA & EPA-III PRG \\
\hline VDIS & 0.26 & $\mathrm{mg} / \mathrm{L}$ & Vanadium, Dissolved & $\overline{N A}$ & EPA-III PRG \\
\hline VTOT & 0.26 & $\mathrm{~mol}$ & Vanadium. Total & $\mathbf{N} / \mathbf{A}$ & EPA-III PRG \\
\hline V48 & 644 & pCin & Vanadium-48 & $014331-97-6$ & Prop. PDWS \\
\hline VINYLA & 37 & $\mathrm{mgl}$ & Vinyi Acetate & $000108-05-4$ & EPA-III PRG \\
\hline $\mathrm{C}_{2} \mathrm{H} 3 \mathrm{CL}$ & 0.002 & $\mathrm{mg} / \mathrm{L}$ & Vinyl Chloride & $000075-01-4$ & PDWS \\
\hline XYLEN & 10 & $\mathrm{mg} / \mathrm{L}$ & Xyienes & $001330-20-7$ & PDWS \\
\hline YB169 & 1830 & pCin & Ytterbium-169 & & Prop. PDWS \\
\hline YB175 & 3110 & pCil & Ytterbium-175 & & Prop. PDWS \\
\hline$Y 88$ & 576 & pCin & Yttrium-88 & & Technical \\
\hline Y90 & 510 & $\mathrm{pCi} / \mathrm{L}$ & Yttrium-90 & $010098-91-6$ & Prop. PDWS \\
\hline Y91 & 576 & $\mathrm{pCi} \Omega$ & Yttrium-91 & $014234-24-3$ & Prop. PDWS \\
\hline Y91M & $1.32 E+05$ & $\mathrm{pCin}$ & Yttrium-91m & $014234-24-3(\mathrm{~m})$ & Prop. PDWS \\
\hline Y92 & 2870 & pCin & Yttrium-92 & $015751-59-4$ & Prop. PDWS \\
\hline Y93 & 1200 & pCin & Yttrium-93 & $014981-70-5$ & Prop. PDWS \\
\hline $\mathrm{ZN}$ & 11 & $\mathrm{mgl}$ & Zinc & NOCAS RN & EPA-III PRG \\
\hline ZNDIS & 11 & $\mathrm{mgl}$ & Zinc, Dissolved & NO CAS RN & EPA-III PRG \\
\hline ZNTOT & 11 & $\mathrm{mgl}$ & Zinc, Total & NO CAS RN & EPA-III PRG \\
\hline ZN65 & 396 & pCin & Zinc-65 & $013982-39-3$ & Prop. PDWS \\
\hline ZN69 & 63100 & $\mathrm{pCi}$ & Zinc-69 & $013982-23-5$ & Prop. PDWS \\
\hline ZN69M & 4220 & pCin & Zinc-69m & $013982-23-5(\mathrm{~m})$ & Prop. PDWS \\
\hline ZR93 & 5090 & pCir & Zirconium-93 & $015751-77-6$ & Prop. PDWS \\
\hline ZR95 & 1460 & pCil & Zirconium-95 & $013967-71-0$ & Prop. PDWS \\
\hline ZR97 & 650 & $\mathrm{pCin}$ & Zirconium-97 & $014928-30-4$ & Prop. PDWS \\
\hline
\end{tabular}


This page is intentionally left blank. 


\section{SRS INVESTIGATION-DERIVED WASTE MANAGEMENT PLAN (U):}

HEALTH-BASED LEVELS FOR

NON-AQUEOUS IDW

CONTAINERIZATION DETERMINATIONS 
WSRC-RP-94-1227, Rev. 2

This table applies to non-aqueous IDW (soil and slurries) and lists chemical constituent action levels used to determine whether or not non-aqueous IDW requires containerization and subsequent management under best management practices. In some cases, non-aqueous IDW exceeding the levels listed in Appendix B that require containerization and management under best management practices may be determined to be RCRA hazardous waste and would then require further management under RCRA auspices.

Risk management of radioactive elements is discussed in Section 2.1 in the text. The final page of the table in this appendix provides IDW Screening Levels for the man-made radionuclides that are found at SRS waste units. These levels are based on isotopic analysis for samples that exceed the screening gross alpha and non-volatile beta/gamma levels described in Section 2.1. IDW containing isotopes exceeding these levels will be managed in accordance with the IDW management plan.

The risk-based levels were calculated using Risk-Based Concentration Algorithms developed by Roy L. Smith of EPA Region III (Fourth Quarter 1994, Nov. 8, 1994) for residential exposure to contaminated soil for chemicals. These algorithms are identical to those employed in the review draft of Soil Screening Gujdelines (EPA5540/R-94/101, December 1994). Both cancer risk and noncancer levels are listed. The cancer risk level is set at the 1.0E-06 risk level. The noncancer hazard quotient is set at 1.0. The Soil Screening Guideline for lead of $400 \mathrm{mg} / \mathrm{kg}$ is obtained from Revised Interim Soil Lead Guidance on Remedial Actions for Superfund Sites and RCRA Corrective Action Facilities (OSWER Directive \#9355.4-12, July 14, 1994).

Where SRS-wide soil background levels exceed the health-based levels (HBLs), the soil background level will be the HBL. SRS soil background levels for metals are derived from Geochemical and Physical Properties of Soils and Shallow Sediments at the Savannah River Site (U) (WSRC-RP-90-1031, August 30, 1990). The HBL is set by calculating the mean and adding two times the standard deviation of the detected concentrations, to conservatively estimate a reasonable upper-bound background value within the range of observed background values. Note, in no case will the HBL equal or exceed the maximum background value measured.

Unit-specific soil background levels are also determined for waste units at SRS. These unit-specific background values may vary greatly fom (exceed) the SRS-wide background values due to unit-specific mineralogy in the sediments. This variance in unit-specific mineralogy is due to different mineralogy of parent materials for the sedimentary deposits surrounding and underlying any specific waste unit. Where the unit-specific background exceeds the SRS-wide background and the PRG/Soil Screening Guideline value, the unitspecific background value will be used as the HBL for that specific waste unit. 
NOTES FOR TABLE USE:

1) Units represent mass (milligrams, $\mathrm{mg}$ ) per kilogram ( $\mathrm{kg}$ ) of soil or activity (picoCuries, $\mathrm{pCi}$ ) per gram (g) of soil.

2) Not all constituents included in this list are hazardous according to the definition of the South Carolina Hazardous Waste Management Regulations R.61-79.

3) The Chemical Abstract Service Registry Numbers (CASRN) are unique to each radionuclide, chemical or mixture of chemicals identified in the list.

4) Voids in the table indicate the lack of both cancer potency slope factor (SF) and noncancer reference dose (RAD) data in the IRIS and HEAST databases. The IRIS database is current as of December 1, 1994, and the HEAST publication is current as of November 1993.

5) This table is used to determine acceptable levels of contaminants in non-aqueous IDW that does not require management using best management practices. Nonaqueous IDW that exceeds these Health-Based Levels will be managed using best management practices in accordance with the IDW Management Plan.

6) The Health-Based Limits (HBLs) are annotated with " $e$ " for limits derived from Soil Screening Guidance (EPA/540/R-94/101, OSWER Directive 9355.4-14FS, December 1994), with "b" for SRS background levels, with "c" for Region III PRG cancer risk values, and with " $n$ " for Region III PRG noncancer hazard index values.

7) The HBLs are set according to the following priority:

- EPA Region III PRGs/EPA Draft Soil Screening Guidelines (EPA/540/R94/101) based on a residential exposure scenario, using a lifetime cancer risk of $1.0 \mathrm{E}-06$ and a hazard quotient of 1.0 . The lowest of the cancer or noncancer PRGs is selected as the HBL. If SRS-wide background levels exceed the EPA Region III PRGs/Soil Screening Guidelines, then the SRS-wide background levels are used as the HBLs. Radionuclides also consider the Practical Quantitation Limit for the isotopes in soil in determining the DW screening level.

- The HBL for lead is set at $400 \mathrm{mg} / \mathrm{kg}$ based on Revised Interim Soil Lead Guidance on Remedial Actions for Superfund Sites and RCRA Corrective Action Facilities (OSWER Directive \#9355.4-12, July 14, 1994). 


\begin{tabular}{|c|c|c|c|c|c|c|}
\hline $\begin{array}{c}\text { Appendix B } \\
\text { HBL's for Non-Aqueous IDW } \\
\text { CHEMICAL NAME }\end{array}$ & CASRN & $\begin{array}{c}\text { RPDo } \\
\mathrm{mg} / \mathrm{k} / \mathrm{day}\end{array}$ & $\begin{array}{c}\text { RIDi } \\
\mathrm{mg} / \mathrm{kg} / \text { day }\end{array}$ & $\begin{array}{c}\text { CPSo } \\
\mathrm{kg} \text {-day/mg }\end{array}$ & $\begin{array}{c}\text { CPSi } \\
\mathrm{kg}-\text {-day/mg }\end{array}$ & $\begin{array}{l}\text { Health-Based } \\
\text { Limt } \\
\text { mg/kg }\end{array}$ \\
\hline acenaphthene & 83-32-9 & $6.00 E-02$ & & & & $4.69 E+03 n$ \\
\hline acenaphthylene & $208-96-8$ & & & & & \\
\hline acephate & $30560-19-1$ & $4.00 E-03$ & & $8.70 E-03$ & & $7.34 E+01 C$ \\
\hline acetaldehyde & $75-07-0$ & & 2.57E-03 & & & \\
\hline acetate, ethy & $141-78-6$ & 9.00E-01 & & & & $7.04 E+04 n$ \\
\hline acetic acid, 2,4,5-trichlorophenoxy & $93-76-5$ & $1.00 E-02$ & & & & $7.82 E+02 n$ \\
\hline acetochlor & $34256-82-1$ & $2.00 E-02$ & & & & $1.56 E+03 n$ \\
\hline acetone & $\longdiv { 6 7 - 6 4 - 1 }$ & $1.00 E-01$ & & & & $7.82 E+03 n$ \\
\hline acetone cyanohydrin & $75-86-5$ & $7.00 E-02$ & $2.86 E-03$ & & & $5.48 E+03 n$ \\
\hline acetonitrile & $75-05-8$ & $6.00 E-03$ & $1.43 E-02$ & & & $4.69 E+02 n$ \\
\hline acetophenone & $98-86-2$ & $1.00 E-01$ & & & & $7.82 E+03 n$ \\
\hline aceny chloride & $75-36-5$ & & & & & \\
\hline acinuorten, sodium & $62476-59-9$ & $1.30 E-02$ & & & & $1.02 E+03 n$ \\
\hline acrolein & $107-02-8$ & $2.00 E-02$ & 5.71E-06 & & & $1.56 E+03 n$ \\
\hline acrylamide & $79-06-1$ & $2.00 E-04$ & & $4.50 E+00$ & $4.50 E+00$ & $1.42 E-01 \mathrm{C}$ \\
\hline acrylate, 2 -ethoxyethy & $106-74-1$ & & & & & \\
\hline acryate, ethy & $140-88-5$ & & & $4.80 E-02$ & & $1.33 E+01 C$ \\
\hline acnlic acid & $79-10-7$ & $5.00 E-01$ & $2.86 E-04$ & & & $3.81 E+04 n$ \\
\hline acryonitrile & $107-13-1$ & $1.00 E-03$ & $5.71 E-04$ & 5.40E-01 & $2.40 \mathrm{E}-01$ & $1.18 E+00 c$ \\
\hline adiponitrile & $111169-3$ & & & & & \\
\hline alachlor & $15972-60-8$ & $1.00 E-02$ & & B.00E-02 & & $7.98 \mathrm{E}+00 \mathrm{C}$ \\
\hline alar & $1596-84-5$ & $1.50 E-01$ & & & & $1.17 E+04 n$ \\
\hline aldicarb & $116-06-3$ & $1.00 E-03$ & & & & $7.82 E+09 n$ \\
\hline aldicarb sulfone & $1646-88-4$ & $1.00 E-03$ & & & & $7.82 E+09 n$ \\
\hline aldrin & $309-00-2$ & $3.00 E-05$ & & $1.70 E+01$ & $1.70 E+01$ & $3.76 E-02 c$ \\
\hline allidochior & $93-71-0$ & & & & & \\
\hline ally & $74223-64-6$ & $2.50 E-01$ & & & & $1.96 E+04 n$ \\
\hline ally alcohol & $107 \cdot 18-6$ & $5.00 E-03$ & & & & $3.91 E+02 n$ \\
\hline altyl chloride & $107-05-1$ & & $2.86 \mathrm{E}-04$ & & & \\
\hline aluminum & $7429-90-5$ & & & & & $3.25 E+04 \quad b$ \\
\hline aluminum phosphide & $20859-73-8$ & $4.00 E-04$ & & & & $3.13 E+01 n$ \\
\hline amdro & $67485-29-4$ & $3.00 E-04$ & & & & $2.35 E+01 n$ \\
\hline ametryn & $834-12-8$ & $9.00 E-03$ & & & & $7.04 E+02 n$ \\
\hline amine, $\mathrm{N}$-nitrosodiphenyt- & $86-30-6$ & & & $4.90 E-03$ & & $1.30 E+02 c$ \\
\hline amine, $n, n$-diphenyt & $122-39-4$ & $2.50 E-02$ & & & & $1.96 E+03 n$ \\
\hline amine, $n$-nitroso-di-n-buty & $924-16-3$ & & & $5.40 E+00$ & $5.40 E+00$ & $1.18 E-01 \mathrm{C}$ \\
\hline amine, n-nitroso-di-n-propy & $621-64-7$ & & & $7.00 E+00$ & & $8.12 E-02 c$ \\
\hline amitraz & $33089-61.1$ & $2.50 E-03$ & & & & $1.96 E+02 n$ \\
\hline ammonia & 766441.7 & & $2.86 \mathrm{E}-02$ & & & \\
\hline ammonium acetate & $631-69-8$ & & & & & \\
\hline ammonium methacryate & $16325-47-6$ & & & & & \\
\hline ammonium sulfamate & $77773-06-0$ & $2.00 E-01$ & & & & $1.56 E+04 n$ \\
\hline aniline & $62-53-3$ & & $2.86 E-04$ & $5.70 E-03$ & & $1.12 E+02 c$ \\
\hline aniline hydrochloride, 2,4,6-tnchloro & $33663-50-2$ & & & $2.90 \mathrm{E}-02$ & & $2.20 E+09 \mathrm{C}$ \\
\hline aniline hydrochlonde, 2,4-dimethy & $21436-96-4$ & & & $5.80 E-01$ & & $1.10 E+00 \mathrm{C}$ \\
\hline aniline hydrochloride 4-chloro-2-methy & $3165-93-3$ & & & $4.60 E-01$ & & $1.39 E+00 \mathrm{c}$ \\
\hline aniline, 2.4.6-trichloro & $634-93-5$ & & & $3.40 E-02$ & & $1.88 E+01 \mathrm{c}$ \\
\hline aniline, 2.4-dimethy & $95-68-1$ & & & $7.50 E-01$ & & $8.52 E-01 \mathrm{C}$ \\
\hline aniline, 2-chloro & $95-59-2$ & & & & & \\
\hline aniline. 3-chloro & $108-42-9$ & & & & & \\
\hline aniline 4-chloro & $106-47-8$ & $4.00 E-03$ & & & & $3.13 E+02 n$ \\
\hline aniline 4-chloro-2-methy & $95-69-2$ & & & $5.80 \mathrm{E}-01$ & & $9.10 E+00 \mathrm{C}$ \\
\hline
\end{tabular}

Shaded RTD and CPS values obtained from Region III Risk-Based Concentration Table. Fourth Quarter 1994

$b=$ SRS background value

$c=$ Cancer Risk

$e=$ EPA Soil Screening Guidance (EPAJ540/R-94/101, December 1994)

$n=$ Hazard index Page 1 


\begin{tabular}{|c|c|c|c|c|c|c|}
\hline $\begin{array}{l}\text { Appendix B } \\
\text { HBL's for Non-Aqueous IDW } \\
\text { CHEMICAL NAME. }\end{array}$ & CASRN & $\begin{array}{c}\text { RDDo } \\
\text { mg/kg/day }\end{array}$ & $\begin{array}{c}\text { RTDi } \\
\text { mg/kg/day }\end{array}$ & $\begin{array}{c}\text { CPSo } \\
\text { kg-day/mg }\end{array}$ & $\begin{array}{c}\text { CPSi } \\
\text { kg-day/mg }\end{array}$ & $\begin{array}{c}\text { Health-Based } \\
\text { Lmit } \\
\text { molkg }\end{array}$ \\
\hline aniline, $N, N$-diethyl & $91-66-7$ & & & & & \\
\hline aniline, n,n-dimethy & $121-697$ & $2.00 E-03$ & & & & $1.56 E+02 n$ \\
\hline aniline, n-ethy & $103-69-5$ & & & & & \\
\hline enisidine, ortho- & $90-04-0$ & & & & & \\
\hline anthrecene & $120-12-7$ & $3.00 E-01$ & & & & $2.35 E+04 n$ \\
\hline anthracene, 7,12-dimethylbenz(a) & $57-97-6$ & & & & & \\
\hline entimony & $7440-36-0$ & $4.00 E-04$ & & & & $3.13 E+01 n$ \\
\hline antimony pentoxide & $1314-60-9$ & $5.00 E-04$ & & & & $3.81 E+01 \mathrm{n}$ \\
\hline antimony potassium tartrate & $304-61-0$ & $9.00 \mathrm{E}-04$ & & & & $7.04 E+01 \mathrm{n}$ \\
\hline antimony tetroxide & $1332-81.6$ & $4.00 E-04$ & & & & $3.13 E+01 n$ \\
\hline antimony trioxide & $1309-644$ & 4.00E-04 & & & & $3.13 E+01 n$ \\
\hline apollo & $74115-24-5$ & $1.30 E-02$ & & & & $1.02 E+03 n$ \\
\hline aramite & $140-57-8$ & $5.00 E-02$ & & $2.50 E-02$ & $2.50 E-02$ & $2.55 E+01 \mathrm{C}$ \\
\hline arodor 1016 & $12674-11-2$ & $7.00 E-05$ & & & & $5.48 E+00 n$ \\
\hline aroclor 1248 & $12672-296$ & & & & & \\
\hline arocior 1254 & $11097-69-1$ & $2.50 E-02$ & & & & $1.86 E+03 n$ \\
\hline arsenic & $7440-38-2$ & $3.00 E-04$ & & $1.75 E+00$ & $5.00 E+01$ & $9.44 E+00 \quad b$ \\
\hline arsine & $7784-42-1$ & & $1.43 E-05$ & & & \\
\hline asbestos & $1332-21-4$ & & & & & \\
\hline assure & $76578-14-8$ & $9.00 E-03$ & & & & $7.04 E+02 n$ \\
\hline asulam & $3337-71-1$ & $5.00 \mathrm{E}-02$ & & & & $3.91 E+03 n$ \\
\hline atrazine & $1912-24-9$ & $3.50 E-02$ & & $2.22 \mathrm{E}-01$ & & $2.88 E+00 \mathrm{C}$ \\
\hline avermectin bi & $65195-55-3$ & $4.00 E-04$ & & & & $3.13 E+01 \quad n$ \\
\hline azobenzene & $\longdiv { 1 0 3 - 3 3 - 3 }$ & & & $1.10 E-01$ & $9.10 E-01$ & $5.81 E+00 \mathrm{C}$ \\
\hline barium & $7440-39-3$ & $7.00 \mathrm{E}-02$ & 1.43E-04 & & & $5.50 E+03 e$ \\
\hline banium cyanide & $542-62-1$ & & & & & \\
\hline baygon & $\longdiv { 1 1 4 - 2 6 - 9 }$ & $4.00 E-03$ & & & & $3.13 E+02 n$ \\
\hline bayleton & $43121-43-3$ & $3.00 E-02$ & & & & $2.35 E+03 n$ \\
\hline baythroid & $68359-37-5$ & $2.50 E-02$ & & & & $1.96 E+03 n$ \\
\hline benefin & $1861-40-1$ & $3.00 E-01$ & & & & $2.35 E+04 n$ \\
\hline benomy & $17804-35-2$ & $5.00 E-02$ & & & & $3.81 \mathrm{E}+03 \mathrm{n}$ \\
\hline bentazon & $25057-89-0$ & $2.50 E-03$ & & & & $1.96 E+02 n$ \\
\hline benzal chloride & $98-87.3$ & & & & & \\
\hline benzaldehyde & $100-52.7$ & $1.00 E-01$ & & & & $7.82 E+03 n$ \\
\hline benzaldehyde cyanohydrin & $532.28-5$ & & & & & \\
\hline benzene & $79-43-2$ & & & $2.90 E-02$ & $2.90 \mathrm{E}-02$ & $2.20 E+01 c$ \\
\hline benzene, 1,2.4-tribromo & $\longdiv { 6 1 5 - 5 4 - 3 }$ & $5.00 E-03$ & & & & $3.91 E+02 n$ \\
\hline benzene, 1.2.4-tnichloro & $120-82-1$ & $1.00 E-02$ & $5.71 E-02$ & & & $7.82 E+02 \mathrm{n}$ \\
\hline benzene, 1,2-dinitro & $528-29-0$ & $4.00 E-0.4$ & & & & $3.13 E+01 n$ \\
\hline benzene, 1,3,5-tnnitro & $99-35-4$ & $5.00 \mathrm{E}-05$ & & & & $3.81 E+00 \mathrm{n}$ \\
\hline benzene, 1,3-dinitro & $99-65-0$ & $1.00 E-04$ & & & & $7.82 E+00 \mathrm{n}$ \\
\hline benzene, 1,4-dibromo & $106-37-6$ & $1.00 E-02$ & & & & $7.82 E+02 n$ \\
\hline benzene, 1,4-dinitro & $100-25-4$ & 4.00E-04 & & & & $3.13 E+01 \mathrm{n}$ \\
\hline benzene, m-chloronitro & $88-73-3$ & & & $2.50 E-02$ & & $2.55 E+01 \quad c$ \\
\hline benzene, p-chloronitso & $100-00-5$ & & & $1.80 E-02$ & & $3.55 E+01 \mathrm{c}$ \\
\hline benzenethiol & $108-98-5$ & $1.00 \mathrm{E}-05$ & & & & $7.82 E-01 \mathrm{n}$ \\
\hline benzidine & $92-87-5$ & $3.00 E-03$ & & $2.30 E+02$ & $2.30 E+02$ & $2.78 E-03 \mathrm{C}$ \\
\hline benzidine, 3,3'-dimethy & $119-93-7$ & & & $9.20 E+00$ & & $6.94 E-02 \mathrm{C}$ \\
\hline benzidine, 3,3-dimethoxy & $119-90-4$ & & & $1.40 E-02$ & & $4.56 E+01 c$ \\
\hline benzo(a)anthracene & 56-55-3 & & & 7.30E-01 & & $8.75 E-01 \mathrm{c}$ \\
\hline benzo(a)pyrene & $50-32-8$ & & & $7.30 E+00$ & & 8.75E-02 C \\
\hline benzo(b)fiuoranthene & $205-99-2$ & & & 7.30E-0I & & 8.75E-01 C \\
\hline
\end{tabular}

Shaded RR and CPS values obtained from Region III Risk-Based Concentration Table, Fourth Quarter 1994.

$b=$ SRS background value

$c=$ Cancet Risk

$e=$ EPA Soil Serening Guidance (EPA540/R-94/101, December 1994)

$n=$ Hazard index

Page 2 


\begin{tabular}{|c|c|c|c|c|c|c|}
\hline $\begin{array}{l}\text { Appendix B } \\
\text { HBL's for Non Aqueous IDW } \\
\text { CHEMICAL NAME }\end{array}$ & CASRN & $\begin{array}{c}R D_{0} \\
\text { mokg/day }\end{array}$ & $\begin{array}{c}\text { RIDi } \\
\text { mokg/day }\end{array}$ & $\begin{array}{c}\text { CPSo } \\
\text { kg-day/mg }\end{array}$ & $\begin{array}{c}\text { CPSi } \\
\text { kg-day/mg }\end{array}$ & $\begin{array}{l}\text { Health-Based } \\
\text { Limit } \\
\text { mg/kg }\end{array}$ \\
\hline benzo $(0, h, j)$ perylene & $191-24-2$ & & & & & \\
\hline benzo(j)muoranthene & $205-82-3$ & & & & & \\
\hline benzo(k)iuoranthene & $207-08-9$ & & & W61 & & $8.75 E+00 \mathrm{C}$ \\
\hline benzoic acid & $65-85-0$ & $4.00 E+00$ & & & & $3.13 E+05 n$ \\
\hline benzothiazole, 2-(thiocyanomethythio)- & $21564-17-0$ & $3.00 \mathrm{E}-02$ & & & & $2.35 E+03 n$ \\
\hline benzotrichioride & $98-07-7$ & & & $1.30 E+01$ & & 4.91E-02 C \\
\hline benzyl alcohol & $100-516$ & $3.00 \mathrm{E}-01$ & & & & $2.35 E+04 n$ \\
\hline benzyl chloride & $100-447$ & & & $1.70 E-01$ & & $3.76 E+00 \mathrm{c}$ \\
\hline bentlium & 7440491.7 & $5.00 E-03$ & & $4.30 E+\infty 0$ & $8.40 E+00$ & $1.40 E-01 \mathrm{C}$ \\
\hline bidrin & $\longdiv { 1 4 9 - 6 6 - 2 }$ & $1.00 E-04$ & & & & $7.82 E+00 n$ \\
\hline biphenthrin & $82657-04-3$ & $1.50 E-02$ & & & & $1.17 E+03 n$ \\
\hline bipheny, 1,1- & $92-524$ & $5.00 E-02$ & & & & $3.91 E+03 n$ \\
\hline bis(2-chloroethoxy)methane & $111.91-1$ & & & & & \\
\hline bisphend A & $80-05-7$ & $5.00 E-02$ & & & & $3.91 E+03 n$ \\
\hline boron & $7440-42-8$ & $0.00 E-02$ & 5.71E-03 & & & $7.04 E+03 n$ \\
\hline boron trimuoride & $7637-07-2$ & & $2.00 E-04$ & & & \\
\hline bromoacetone & $598-31-2$ & & & & & \\
\hline bromochloromethane & 7 & & & & & \\
\hline bromodichloromethane & $75-27-4$ & 2.00E-02 & & $6.20 E-02$ & & $1.03 E+01 \mathrm{C}$ \\
\hline bromodifluoromethane & $1511-62-2$ & & & & & \\
\hline bromoform & $75-25-2$ & $2.00 E-02$ & & $7.93 E-03$ & $3.90 \mathrm{E}-03$ & $8.05 E+01 C$ \\
\hline bromomethane & $74-83-9$ & $1.40 E-03$ & 1.43E-03 & & & $1.10 E+02 n$ \\
\hline bromophos & $2104-96-3$ & $5.00 E-03$ & & & & $3.01 E+02 n$ \\
\hline bromotrichloromethane & $75-62-7$ & & & & & \\
\hline bromoxynil & $1689-84-5$ & $2.00 E-02$ & & & & $1.56 E+03 n$ \\
\hline bromoxymil octanoate & $1689-99-2$ & $2.00 E-02$ & & & & $1.56 \mathrm{E}+03 \mathrm{n}$ \\
\hline busan 77 & $31512-74-0$ & & & & & \\
\hline busan 90 & $2491-38.5$ & & & & & \\
\hline butadiene, 1,3- & $106-99-0$ & & & & $9.80 E+00$ & \\
\hline butadiene, 2-chlora-1,3- & $126-99-8$ & $2.00 E-02$ & 2.00E-03 & & & $1.56 \mathrm{E}+03 \mathrm{n}$ \\
\hline butane. 1-chloro & $109-69-3$ & $4.00 E-01$ & & & & $3.13 E+04 n$ \\
\hline butane, 2-chloro & $78-86-4$ & & & & & \\
\hline butanol, 1- & $71-36-3$ & $1.00 E-01$ & & & & $7.82 E+03 n$ \\
\hline butanone, 2- (MEK) & $78-93-3$ & $6.00 E-01$ & 2.86E-01 & & & $4.69 E+04 n$ \\
\hline butene, 1,4-dichlora-2- & $76441-0$ & & & & $9.30 E+00$ & \\
\hline butyate & $2008-41-5$ & $5.00 \mathrm{E}-02$ & & & & $3.91 E+03 n$ \\
\hline butychloride, t- & $507.20-0$ & & & & & \\
\hline butylphthaly butylglycolate (BPBG) & $85-70-1$ & $1.00 \mathrm{E}+00$ & & & & $7.82 E+04 n$ \\
\hline butyric acid. 4-(2,4-dichlorophenoxy) & $94-82-6$ & $8.00 E-03$ & & & & $6.26 E+02 n$ \\
\hline butyric acid 4-(2-methyt-4-chlorophenoxy) & $94-81.5$ & $1.00 E-02$ & & & & $7.82 E+02 n$ \\
\hline butyrolactone gamma- & $96-48-0$ & & & & & \\
\hline cacodylic acid & $75-60-5$ & $3.00 E-03$ & & & & $2.35 E+02 n$ \\
\hline caomium & $7740-43-9$ & $5.00 E-04$ & & & & $3.91 E+01 n$ \\
\hline calcium cyanide & $592-01-8$ & $4.00 E-02$ & & & & $3.13 E+03 n$ \\
\hline caprolactam & $105-60-2$ & $5.00 E-01$ & & & & $3.91 E+04 n$ \\
\hline Captafol & $2425-06-1$ & $2.00 E-03$ & & $8.60 E-03$ & & $7.43 E+04 c$ \\
\hline captan & $\longdiv { 1 3 3 - 0 6 - 2 }$ & $1.30 E-01$ & & $3.50 E-03$ & & $1.82 E+02 c$ \\
\hline carbary & $63-25-2$ & $1.00 E-01$ & & & & $7.82 E+03 n$ \\
\hline carbazole & $86-74-8$ & & & $2.00 E-02$ & & $3.10 E+01 \mathrm{C}$ \\
\hline carbofuran & $1563-66-2$ & $5.00 E-03$ & & & & $3.91 E+02 n$ \\
\hline carbon disulfide & $75-15-0$ & $9.00 E-01$ & $2.86 E-03$ & & & $7.82 E+03 n$ \\
\hline carbon tetrachloride & $56-23-5$ & $7.00 E-04$ & & $1.30 E-01$ & $5.30 E-02$ & $4.91 E+00 \mathrm{C}$ \\
\hline
\end{tabular}

Shaded RID and CPS values obtained from Region III Risk-Based Concentration Table, Fourth Quarter 1994.

$b=$ SRS background value

$c=$ Cancer Risk

$e=$ EPA Soll Screening Guidance (EPA540/R-94/101, December 1994).

$n=$ Hazard index

Page 3 


\begin{tabular}{|c|c|c|c|c|c|c|}
\hline $\begin{array}{c}\text { Appendix B } \\
\text { HBL's for Non-Aqueous IDW } \\
\text { CHEMICAL NAME }\end{array}$ & CASRN & $\begin{array}{c}\text { RTDo } \\
\text { mo/kg/day }\end{array}$ & $\begin{array}{c}R \mathbf{R i} \\
\mathrm{mo} / \mathrm{kg} / \mathrm{day}\end{array}$ & $\begin{array}{c}\text { CPSo } \\
\text { kg-day/mg }\end{array}$ & $\begin{array}{c}\text { CPSi } \\
\text { kg-day/mg }\end{array}$ & $\begin{array}{l}\text { Health-Based } \\
\text { Limit } \\
\text { mo/kg }\end{array}$ \\
\hline carbonyl sulfide & $463-58-1$ & & & & & \\
\hline carbosulfan & $55285-14-8$ & $1.00 E-02$ & & & & $7.82 E+02 n$ \\
\hline carboxin & $5234-68-4$ & $1.00 E-01$ & & & & $7.82 E+03 n$ \\
\hline chlorel & $75-876$ & 2.00E-03 & & & & $1.56 E+02 n$ \\
\hline chloral hydrate & $302-17-0$ & & & & & \\
\hline chloramben & $133-90-4$ & $1.50 E-02$ & & & & $1.17 E+03 n$ \\
\hline chloranil & $\longdiv { 1 1 8 - 7 5 - 2 }$ & & & 4.03E-01 & & $1.58 \mathrm{E}+00 \mathrm{C}$ \\
\hline chlordane & 57.740 & $6.00 E-05$ & & $1.30 E+00$ & $1.30 E+00$ & 4.01E-01 C \\
\hline chloride, othy & $75-00-3$ & & $2.86 E+00$ & & & \\
\hline chlorimuron-ethy & $80982-324$ & $2.00 E-02$ & & & & $1.56 E+03 n$ \\
\hline Chlorine & $7782-50-5$ & $1.00 E-01$ & & & & $7.82 E+03 n$ \\
\hline Chlorine cyanide & $506-774$ & $5.00 E-02$ & & & & $3.01 E+03 n$ \\
\hline chlorine dioxide & $10049-044$ & & 5.71E-05 & & & \\
\hline chlorite (sodium sait) & $7758-19-2$ & & & & & \\
\hline chloroacetaldehyde & $107-20-0$ & & & & & \\
\hline chloroacetic acid & $79-11-8$ & 2.00E-03 & & & & $1.56 E+02 n$ \\
\hline chloroacetophenone, 2- & $532-274$ & & 8.57E-06 & & & \\
\hline chlorobenzene & $108-90-7$ & $2.00 E-02$ & 5.71E-03 & & & $1.56 E+03 n$ \\
\hline chlorobenzilate & $\sqrt{510-15-6}$ & $2.00 E-02$ & & $2.70 E-01$ & $2.70 E-01$ & $2.37 E+00 \mathrm{C}$ \\
\hline chlorobenzoic acid, p- & 7 & $2.00 E-01$ & & & & $1.56 E+04 n$ \\
\hline chlorobenzotrinuoride, 4- & $98-56-6$ & $2.00 E-02$ & & & & $1.56 E+03 n$ \\
\hline chlorocyclohexane, 1,2,3,4,5-pentabroma-6- & $\longdiv { 8 7 - 8 4 \cdot 3 }$ & & & $2.30 E-02$ & & $2.78 E+01 c$ \\
\hline chlorocyclopentadiene & $41851-50.7$ & & & & & \\
\hline chlorodinuoromethane & $75-45-6$ & & $1.43 E+01$ & & & \\
\hline chloroform & $67-66-3$ & $1.00 E-02$ & & $6.10 E-03$ & $8.10 E-02$ & $1.05 E+02 c$ \\
\hline chloromethane & $\overline{74-87.3}$ & & & $1.30 E-02$ & $6.30 \mathrm{E}-03$ & $4.01 E+09 \mathrm{C}$ \\
\hline chloronaphthalene, beta- & $91-587$ & 8.00E-02 & & & & $6.26 E+03 n$ \\
\hline chlorophenoxyacetic acid, 2-methy-4. & $194-74-6$ & $5.00 E-04$ & & & & $3.01 E+01 n$ \\
\hline chloropropane 12 -dibroma-3- & $96-12-8$ & & 5.71E-05 & $1.40 E+\infty 0$ & $2.40 E-03$ & 4.56E-01 C \\
\hline chlorprophans & $1101-21-3$ & $2.00 E-01$ & & & & $1.56 E+04 n$ \\
\hline chlorpynitos & $2921-88-2$ & $3.00 E-03$ & & & & $2.35 E+02 n$ \\
\hline chlorpyrifos methy & $5598-13-0$ & $1.00 E-02$ & & & & $7.82 E+02 n$ \\
\hline chlorsulfuron & $64902-72-3$ & $5.00 E-02$ & & & & $3.91 E+03 n$ \\
\hline chlorthalonil & $1897-45-6$ & $1.50 E-02$ & & $1.90 E-02$ & & $5.81 E+01 \quad C$ \\
\hline chlorthiophos & $60238-56-4$ & $8.00 E-04$ & & & & $6.26 E+01 n$ \\
\hline chromium (hexavalent) & $18540-29-9$ & $5.00 E-03$ & & & $4.10 E+01$ & $3.91 E+02 n$ \\
\hline chromium (trivalent) & $16065-83-1$ & $1.00 E+00$ & & & & $7.82 E+04 n$ \\
\hline chrysene & 218.04 .9 & & & 7.30503 & & $8.75 E+01 \mathrm{c}$ \\
\hline coke oven emissions & $8007-45-2$ & & & & $2.20 E+00$ & \\
\hline copper & $77440-50-8$ & $3.70 E-02$ & & & & $2.89 E+03 n$ \\
\hline copper gyanide & $544-92-3$ & $5.00 E-03$ & & & & $3.81 E+02 n$ \\
\hline creosote, coal tar & $8001-58-9$ & & & & & \\
\hline eresol, 2.6-dinitro-p- & $609-93-8$ & & & & & \\
\hline cresol, 4,6-dinitro-o- & $534-52.1$ & & & & & \\
\hline cresol, p-chloro-m- & $59-50-7$ & & & & & \\
\hline crotonaldehyde & $123-73-9$ & & & $9.90 E+00$ & & $3.36 E-01 \mathrm{C}$ \\
\hline cumene & $988-82-8$ & $4.00 E-02$ & 2.57E-03 & & & $3.13 E+03 n$ \\
\hline granazine & $21725-46-2$ & $2.00 E-03$ & & $8.40 E-01$ & & $7.60 E-01 \mathrm{C}$ \\
\hline cyanide & $57.12-5$ & $2.00 E-02$ & & & & $1.60 E+03$ \\
\hline cyanogen & $460-19-5$ & $4.00 E-02$ & & & & $3.13 E+03 n$ \\
\hline gyanogen bromide & $506-68-3$ & 9.00E-02 & & & & $7.04 E+03 n$ \\
\hline eycloate & $11134-23-2$ & & & & & \\
\hline
\end{tabular}

Shaded RTD and CPS values obtained trom Region III Risk-Based Concentration Table. Fourth Quarter 1994.

$b=$ SRS background value

$c=$ Cancer Risk

$e=$ EPA Soil Scroening Guidance (EPA540/R-94/101, December 1994).

$n=$ Hazard Index $\quad$ Page 4 


\begin{tabular}{|c|c|c|c|c|c|c|}
\hline $\begin{array}{l}\text { Appendix B } \\
\text { HBL's for Non-Aqueous IDW } \\
\text { CHEMICAL NAME. }\end{array}$ & CASRN & $\begin{array}{c}\text { RDDo } \\
\text { mo/kg/day }\end{array}$ & $\begin{array}{c}\text { RfDi } \\
\mathrm{mg} / \mathrm{kg} / \mathrm{day}\end{array}$ & $\begin{array}{c}\text { CPSo } \\
\text { kg-day/mg }\end{array}$ & $\begin{array}{c}\text { CPSi } \\
\text { kg-day/mg }\end{array}$ & $\begin{array}{l}\text { Health-Based } \\
\text { Limit } \\
\text { mo/kg }\end{array}$ \\
\hline cyclohexand & $108-93-0$ & & & & & \\
\hline Cyclohexanone & $108-94-1$ & $5.00 \mathrm{E}+00$ & & & & $3.91 E+05 n$ \\
\hline gyclohexene, 4-vinyt-1- & $100-40-3$ & & & & & \\
\hline gyctohexylamine & $108-91-8$ & $2.00 E-01$ & & & & $1.56 E+04 n$ \\
\hline Srclopentadiene & $542-92-7$ & & & & & \\
\hline oyhalothrinkarate & $68085-85-8$ & $5.005-03$ & & & & $3.01 E+02$ n \\
\hline cypermethrin & $52315-07-8$ & $1.00 E-02$ & & & & $7.82 E+02 n$ \\
\hline Cyromezine & $66125-27-8$ & $7.50 E-03$ & & & & $5.87 E+02 n$ \\
\hline dacthel & $1861-32-1$ & $1.00 E-02$ & & & & $7.82 E+02 n$ \\
\hline dalapon & $75-990$ & $3.00 E-02$ & & & & $2.35 E+03 n$ \\
\hline danitol & $39515-41-8$ & 2.50E-02 & & & & $1.26 E+03 n$ \\
\hline ddd, 4,4:- & $72-54-8$ & & & $2.40 E-01$ & & $2.66 E+00 c$ \\
\hline dde, 4,4- & $72-55-9$ & & & $3.40 E-01$ & & $1.88 E+00 \mathrm{C}$ \\
\hline $\operatorname{det}, 4,4^{-}$ & $50-29-3$ & 5.00E-04 & & 3.40E-01 & 3.40E-01 & $1.88 E+00 \mathrm{C}$ \\
\hline decabromodipheny ether & $1163-19-5$ & $1.00 E-02$ & & & & $7.82 E+02 n$ \\
\hline demeton & $8065-48-3$ & $4.00 E-05$ & & & & $3.13 E+00 \mathrm{n}$ \\
\hline di(2-ethyihexy) adipate & $103-23-1$ & $6.00 E-01$ & & $1.20 E-03$ & & $5.32 E+02 C$ \\
\hline dialiate & $2303-16-4$ & & & $6.10 E-02$ & & 1.05E+01 C \\
\hline diazinon & $333-41-5$ & $9.00 E-04$ & & & & $7.04 E+01 n$ \\
\hline diazomethane & $334-68-3$ & & & & & \\
\hline dibenz(e,h)anthracene & $53-70-3$ & & & 830500 & & $8.75 E-02 \subset$ \\
\hline dibenzofuran & $132-64-9$ & & & & & \\
\hline dibenzofurans, brominated & JNO CASRN & & & & & \\
\hline dibromochloromethane & $124-48-1$ & $2.00 E-02$ & & 8.40E-02 & & $7.60 E+00 \subset$ \\
\hline dibromodichloromethane & $594-18-3$ & & & & & \\
\hline dibromodiphenyl ether, p.p'- & $2050-47.7$ & & & & & \\
\hline dibromoethane, 1,2- & $106-93-4$ & & 5.74E-05 & $8.50 E+01$ & $7.60 E-01$ & 7.51E-03 $\mathrm{C}$ \\
\hline dicamba & $1918-00-9$ & $3.00 E-02$ & & & & $2.35 E+03 n$ \\
\hline dichlorobenzene, 1.2 - & $95-50-1$ & $9.00 E-02$ & $5.71 E-02$ & & & $7.04 E+03 n$ \\
\hline dichlorobenzene, 1,3- & $541-73-1$ & & & & & \\
\hline dichlorobenzene, 1,4- & $106-46-7$ & & $2.29 E-01$ & $2.40 E-02$ & & $2.66 E+01 C$ \\
\hline dichlorobenzidine, 3,3- & $94-94-1$ & & & $4.50 E-01$ & & $1.42 E+00 \mathrm{c}$ \\
\hline dichlorodifluoromethane & $75-71-8$ & $2.00 E-01$ & 5.71E-02 & & & $1.56 E+04 n$ \\
\hline dichloroethane, 1,1- & $75-34-3$ & $1.00 E-01$ & $1.43 E-01$ & & & $7.82 E+03 n$ \\
\hline dichloroethane. 1,2- & $107-06-2$ & & & $9.10 E-02$ & $9.10 E-02$ & $7.02 E+00 \mathrm{C}$ \\
\hline dichloroethene, 1,1- & $75-35-4$ & $9.00 E-03$ & & $6.00 E-01$ & $1.20 E+00$ & $1.06 E+00 \mathrm{C}$ \\
\hline dichloroethene 1,2-(mxed isomers) & $540.59-0$ & $9.00 E-03$ & & & & $7.04 E+02 n$ \\
\hline dichloroethene, cis-1,2- & $156-59-2$ & $1.00 \mathrm{E}-02$ & & & & $7.82 E+02 n$ \\
\hline dichloroethene trans-1.2- & $156-60-5$ & $2.00 E-02$ & & & & $1.56 \mathrm{E}+03 \mathrm{n}$ \\
\hline dichlorophenol, 2.3- & $576-24-9$ & & & & & \\
\hline dichlorophenol, 2.4- & $120-83-2$ & $3.00 E-03$ & & & & $2.35 E+02 n$ \\
\hline dichlorophenol, 2,5 & $583-78-8$ & & & & & \\
\hline dichlorophenol, 2.6- & $87-65-0$ & & & & & \\
\hline dichlorophenol, 3,4- & $95-77-2$ & & & & & \\
\hline dichiorophenol, 3,5- & $591-35-5$ & & & & & \\
\hline dichlorophenoxyacetic acid, $2.4-$ & $94-75-7$ & $1.00 E-02$ & & & & $7.82 E+02 n$ \\
\hline dichloropropane, 1,1- & $78-99-9$ & & & & & \\
\hline dichloropropane, 1,2 & $78-87-5$ & & $1.14 E-03$ & $6.80 E-02$ & & $9.39 E+00 \mathrm{c}$ \\
\hline dichloropropane, 1,3- & $142-28-9$ & & & & & \\
\hline dichloropropane, 2,2- & $594-20-7$ & & & & & \\
\hline dichloropropanol, 2,3 & $616-23-9$ & 3.00E-03 & & & & $2.35 E+02 n$ \\
\hline dichloropropene, 1,3 & $542-75-6$ & $3.00 \mathrm{E}-04$ & 5.71E-03 & $1.80 E-01$ & $1.30 E-01$ & $3.55 E+00 \mathrm{c}$ \\
\hline
\end{tabular}

Shaded RID and CPS values obtained from Region III Risk-Based Concentration Table, Fourth Quarter 1994.

$b=S R S$ background value

$c=$ Cancer Risk

$e=$ EPA Soil Screening Guidance (EPA540/R-94/101, December 1994).

$n=$ Hazard index 


\begin{tabular}{|c|c|c|c|c|c|c|}
\hline $\begin{array}{c}\text { Appendix B } \\
\text { HBL's for Non-Aqueous IDW } \\
\text { CHEMICAL NAME }\end{array}$ & CASRN & $\begin{array}{c}\text { RiDo } \\
\text { mo/kg/day }\end{array}$ & $\begin{array}{c}\text { RTDi } \\
\text { mo/kg/day }\end{array}$ & $\begin{array}{c}\text { CPSo } \\
\mathrm{kg} \text {-day/mg }\end{array}$ & $\begin{array}{c}\text { CPSi } \\
\text { kg-day/mg }\end{array}$ & $\begin{array}{c}\text { Health-Based } \\
\text { Limit } \\
\text { mg/kg }\end{array}$ \\
\hline dichtorprop & $120-36-5$ & & & & & \\
\hline dichlonos & $62-73.7$ & 5.00E-04 & $1.43 E-04$ & $2.90 E-01$ & & $2.20 E+00 c$ \\
\hline dicofol & $115-32-2$ & & & 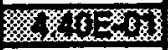 & & $1.45 E+00 \mathrm{c}$ \\
\hline dicyclopentadiene & $77-73-6$ & $3.00 E-02$ & 5.71E-05 & & & $2.35 E+03 n$ \\
\hline dieldrin & $60-57.1$ & 5.00E-05 & & $1.60 E+01$ & $1.60 E+01$ & $3.99 E-02 \mathrm{C}$ \\
\hline diesel engine emissions & NO CASRN & & $1.43 E-03$ & & & \\
\hline diethyl sulfate & $64-67-5$ & & & & & \\
\hline diethylene glycol dinitrate & $693-21-0$ & & & & & \\
\hline diethytformamide & $617-84-5$ & $1.10 E-02$ & & & & $8.60 E+02 n$ \\
\hline diethyiphthalate & $84-66-2$ & $8.00 E-01$ & & & & $6.26 E+04 n$ \\
\hline diethyistibesterol & $56-53-1$ & & & $4.70 E+03$ & & $1.36 \mathrm{E}-04 \mathrm{C}$ \\
\hline difenzoquat & $43222-48-6$ & $8.00 E-02$ & & & & $6.26 \mathrm{E}+03 \mathrm{n}$ \\
\hline dillubenzuron & $35367-38-5$ & $2.00 E-02$ & & & & $1.56 \mathrm{E}+03 \mathrm{n}$ \\
\hline disocyanate, 1,6-hexamethylene & $822-06-0$ & & $2.86 E-06$ & & & \\
\hline disopropy methyiphosphonate & $9445-75-6$ & $8.00 E-02$ & & & & $6.26 E+03 n$ \\
\hline dimethipin & $55290-647$ & $2.00 E-02$ & & & & $1.56 E+03 n$ \\
\hline dimethoate & $60.51-5$ & $2.00 E-04$ & & & & $1.56 E+01 n$ \\
\hline dimethylamine & $124-40-3$ & & & & & \\
\hline dinoseb & $88-85-7$ & $1.00 E-03$ & & & & $7.82 E+01 \quad n$ \\
\hline dioxane, 1,4- & $123-91-1$ & & & $1.10 E-02$ & & $5.81 E+04 \mathrm{c}$ \\
\hline dioxin $(2,3,7,8-T C D D)$ & $1746-01-6$ & & & $1.50 \mathrm{E}+05$ & $1.50 \mathrm{E}+05$ & $4.26 \mathrm{E}-06 \mathrm{C}$ \\
\hline diphenamid & $957-51-7$ & $3.00 E-02$ & & & & $2.35 E+03 n$ \\
\hline diquat & $85-00-7$ & $2.20 E-03$ & & & & $1.72 E+02 n$ \\
\hline direct black 38 & 1937.37 .7 & & & $8.60 E+00$ & & $7.43 E-02 \quad \mathrm{C}$ \\
\hline direct blue 6 & $2602-46-2$ & & & $8.10 E+00$ & & $7.89 \mathrm{E}-02 \mathrm{C}$ \\
\hline direct brown 95 & $16071-86-6$ & & & $9.30 E+00$ & & 6.87E-02 C \\
\hline direct lightfast blue & $4399-55-7$ & & & & & \\
\hline direct sky blue 6B & $2610-05-1$ & & & & & \\
\hline disulfoton & $298-04-4$ & 4.00E-05 & & & & $3.13 E+00 n$ \\
\hline dithiane, 1,4- & $505-29-3$ & $9.00 E-02$ & & & & $7.82 E+02 n$ \\
\hline dithiopropyicarbamate, s-ethyt & $759-94-4$ & $2.50 E-02$ & & & & $1.96 E+03 n$ \\
\hline diuron & $330-54-1$ & $2.00 E-03$ & & & & $1.56 E+02 n$ \\
\hline dodecanoate, 2-ethoxyethanol & $106-13-8$ & & & & & \\
\hline dodine & $2439 \cdot 10-3$ & 4.00E-03 & & & & $3.13 E+02 n$ \\
\hline endosulfan & $115-29-7$ & $6.00 \mathrm{E}-03$ & & & & $4.69 \mathrm{E}+02 \mathrm{n}$ \\
\hline endothall & $145-73-3$ & 2.00E-02 & & & & $1.56 \mathrm{E}+03 \mathrm{n}$ \\
\hline endrin & $\sqrt{72-20-8}$ & $3.00 E-04$ & & & & $2.35 E+01 \quad n$ \\
\hline environmental tobbaco smoke & NO CAS RN & & & & & \\
\hline epichlorohydnn & $106-89-8$ & $2.00 E-03$ & $2.86 E-04$ & $9.90 E-03$ & $4.20 E-03$ & $6.45 E+01 \quad 9$ \\
\hline epoxybutane, 1,2- & $106-88-7$ & & $5.71 E-03$ & & & \\
\hline ethane, 1,1,1-trichloro & $71-55-6$ & & & & & \\
\hline ethane, 1,1,2-trichloro & $170-00-5$ & $4.00 E-03$ & & $5.70 E-02$ & $5.70 E-02$ & $1.12 E+01 c$ \\
\hline ethane, 1,1,2-trichloro-1,2,2-triluoro & 76-13-1 & $3.00 E+01$ & $8.57 E+00$ & & & $2.35 E+06 \quad n$ \\
\hline ethane, 1,1-dinuoro & $75-37-6$ & & $1.14 E+01$ & & & \\
\hline ethanol acetate, 2-ethoxy & $1119-15-9$ & $3.00 E-01$ & & & & $2.35 E+04 \mathrm{n}$ \\
\hline ethanol, 2-ethoxy & $1110-80-5$ & 4.00E-01 & 5.71E-02 & & & $3.13 E+04 n$ \\
\hline ethephon & $16672-87-0$ & $5.00 E-03$ & & & & $3.91 E+02 n$ \\
\hline ether, 2.4.4'-trichloro-2'-hydroxydipheny & $3380-34.5$ & & & & & \\
\hline ether, 2-chloroethytwiny & $110-75-8$ & & & & & \\
\hline ether, 4-bromophenyiphenyl & $109-55-3$ & & & & & \\
\hline ether. bes(2-chloroethy) & $119-444$ & & & $1.10 E+00$ & $1.10 E+\infty 0$ & $5.81 E-01 \mathrm{C}$ \\
\hline ether, bis (2-chloroisopropy) & $39638-32-9$ & $4.00+2$ & & $7.00 E-02$ & $3.50 E-02$ & $9.12 E+00 c$ \\
\hline
\end{tabular}

Shaded RID and CPS values obtained from Region III Risk-Based Concentration Table, Fourth Quarter 1994.

$b=$ SRS background value

$c=$ Cancer Risk

$e=$ EPA Soil Screening Guidance (EPA540/R-94/101, December 1994).

$n=$ Hazard Index

Page 6 


\begin{tabular}{|c|c|c|c|c|c|c|}
\hline $\begin{array}{c}\text { Appendix B } \\
\text { HBL's for Non-Aqueous IDW } \\
\text { CHEMICAL NAME }\end{array}$ & CASRN & $\begin{array}{c}\text { RTDo } \\
\mathrm{mg} / \mathrm{kg} / \mathrm{day}\end{array}$ & $\begin{array}{c}\text { RTDi } \\
\text { mg/ko/day }\end{array}$ & $\begin{array}{c}\text { CPSo } \\
\text { kg-dayimg }\end{array}$ & $\begin{array}{c}\text { CPSi } \\
\text { kg-day/mg }\end{array}$ & $\begin{array}{l}\text { Health-Based } \\
\text { Linkt } \\
\text { mg/kg }\end{array}$ \\
\hline ether, bis(chloromethy) & $542-88-1$ & & & $2.20 E+02$ & $2.20 E+02$ & $200 E 03 \mathrm{C}$ \\
\hline ether, chloromethymethy & $107-30-2$ & & & & & \\
\hline ether diethylene olycol monobuty & $112-34-5$ & & 5.71E-03 & & & \\
\hline ether, diethylene olycol monoethy & $111-90-0$ & $2.00 E+00$ & & & & $1.56 E+05 n$ \\
\hline ether, ethy & $60-297$ & $2.00 E-01$ & & & & 1.56E+04 $n$ \\
\hline ether, ethyene olycol monobuty & $111-76-2$ & & 5.71E-03 & & & \\
\hline ether, nonabromodipheny & $63936-56-1$ & & & & & \\
\hline ether, propylene olycol monoethy & $156902-4$ & $7.00 E-01$ & & & & $5.48 E+04 n$ \\
\hline ether, propylene olycol monomethy & $107-98-2$ & $7.00 E-01$ & 5.71E-01 & & & $5.48 E+04 n$ \\
\hline ether, triethylene olvcol monobuty & $143-226$ & & & & & \\
\hline ether, triethylene olycol monoethy & $112-50-5$ & & & & & \\
\hline ethion & $563-12-2$ & $5.00 E-04$ & & & & $3.91 E+01 n$ \\
\hline ethoprop & $13194-48-4$ & & & & & \\
\hline ethoxyethanol phosphated, 2 - & $68554-00-7$ & & & & & \\
\hline ethy carbamate & $51-796$ & & & & & \\
\hline ethy'p-nitropheny' phenylphosphorothioate & $2104-64-5$ & $1.00 E-05$ & & & & $7.82 E-01 n$ \\
\hline ethybenzene & $100-41-4$ & $1.00 \mathrm{E}-01$ & 2.86E-01 & & & $7.82 E+03 n$ \\
\hline ethylene cyanohydrin & $109-74-8$ & 3.00E-01 & & & & $2.35 E+04 n$ \\
\hline ethylene diamine & $107-15-3$ & $2.00 E-02$ & & & & $1.56 E+03 n$ \\
\hline ethylene glycol & $107-21-1$ & $2.00 E+00$ & & & & $1.56 E+05 n$ \\
\hline ethylene oxide & $75-21-8$ & & & $1.02 E+00$ & $3.50 E-01$ & 6.26E $01 \mathrm{C}$ \\
\hline ethyiene thiourea & $\longdiv { 8 5 - 4 5 - 7 }$ & $8.00 E-05$ & & $1.10 E-01$ & & $5.81 E+00 C$ \\
\hline ethyeneimine & $151-56-4$ & & & & & \\
\hline ethylnitrosourea & $\longdiv { 7 5 9 - 7 3 - 9 }$ & & & $1.40 E+02$ & & 4.56E-03 C \\
\hline ethylphthaly ethyglycolate (EPEG) & $84-72-0$ & $3.00 E+00$ & & & & $235 E+05 n$ \\
\hline express & $101200-48-0$ & $8.00 E-03$ & & & & $6.26 E+02 n$ \\
\hline fenamiphos & $22224-92-6$ & 2.50E-04 & & & & $1.96 E+01 \mathrm{n}$ \\
\hline fuometuron & $2164-17-2$ & $1.30 E-02$ & & & & $1.02 \mathrm{E}+03 \mathrm{n}$ \\
\hline fuoranthene & $206-44-0$ & 4.00E-02 & & & & $3.13 E+03 n$ \\
\hline fuorene & $86-73-7$ & 4.00E-02 & & & & $3.13 E+03 n$ \\
\hline huorine (soluble fluoride) & $7782-41-4$ & $6.00 E-02$ & & & & $4.69 E+03 n$ \\
\hline huridone & $59756-60-4$ & 8.00E-02 & & & & $6.26 E+03 n$ \\
\hline flurprimidol & $56425-91-3$ & $2.00 E-02$ & & & & $1.56 E+03 n$ \\
\hline fiutolanil & $66332.96-5$ & $6.00 E-02$ & & & & $4.69 E+03 n$ \\
\hline fluvalinate & $69409-94-5$ & $1.00 E-02$ & & & & $7.82 E+02 n$ \\
\hline folpet & $133-07-3$ & 1.00E-01 & & $3.50 E-03$ & & $1.82 \mathrm{E}+02 \mathrm{C}$ \\
\hline fomesafen & $72178-02-0$ & & & $1.90 E-01$ & & $3.36 \mathrm{E}+00 \mathrm{C}$ \\
\hline fonotos & $944-22-9$ & $2.00 E-03$ & & & & $1.56 \mathrm{E}+02 n$ \\
\hline formaldehyde & $50-00-0$ & $2.00 E-01$ & & & $4.50 \mathrm{E}-02$ & $1.56 E+04 n$ \\
\hline formaldehyde cyanohydin & $107-16-4$ & & & & & \\
\hline formamide, n,n-dimethy & $68-12-2$ & $1.00 \mathrm{E}-01$ & $8.57 E-03$ & & & $7.82 E+03 n$ \\
\hline formic acid & $64-18-6$ & $2.00 E+00$ & & & & $1.56 E+05 n$ \\
\hline fosetyral & $39148-24-8$ & $3.00 E+00$ & & & & $2.35 E+05 n$ \\
\hline furan & $110-00-9$ & 1.00E-03 & & & & $7.82 \mathrm{E}+01 \mathrm{n}$ \\
\hline furazolidone & $67-45-8$ & & & $3.80 E+00$ & & $1.68 \mathrm{E}-01 \mathrm{C}$ \\
\hline furfural & $98-01-1$ & $3.00 E-03$ & $1.43 E-02$ & & & $2.35 E+02 n$ \\
\hline funium & $531-82-8$ & & & $5.00 E+01$ & & $1.28 \mathrm{E} 02 \mathrm{C}$ \\
\hline furmecyclox & $60568-05-0$ & & & $3.00 E-02$ & & $2.13 E+01 \mathrm{C}$ \\
\hline glufosinate-ammonium & $77182-82-2$ & $4.00 E-04$ & & & & $3.13 E+01 n$ \\
\hline ghycidaldehyde & $765-34-4$ & 4.00E-04 & $2.86 E-04$ & & & $3.13 E+01 n$ \\
\hline ghyphosate & $1071-83-6$ & & & & & \\
\hline halosufuron methy & $100784.20-1$ & & & & & \\
\hline
\end{tabular}

Shaded RID and CPS values obtained from Region III Risk-Based Concentration Table. Fourth Quarter 1994. $b=$ SRS background value

$c=$ Cancet Risk

e = EPA Soil Screening Guidance (EPA540/R-94/101, December 1994).

$n=$ Hazard index $\quad$ Page 7 


\begin{tabular}{|c|c|c|c|c|c|c|}
\hline $\begin{array}{c}\text { Appendix B } \\
\text { HBL's for Non-Aqueous IDW } \\
\text { CHEMICAL NAME }\end{array}$ & CASRN & $\begin{array}{c}\text { RRDo } \\
\text { mo/kg/day }\end{array}$ & $\begin{array}{c}\text { Rroi } \\
\mathrm{mg} / \mathrm{kg} / \mathrm{day}\end{array}$ & $\begin{array}{c}\text { CPSo } \\
\text { kg-day/mg }\end{array}$ & $\begin{array}{c}\text { CPSi } \\
\text { kg-day/mg }\end{array}$ & $\begin{array}{c}\text { Health-Based } \\
\text { Limit } \\
\text { mg/kg }\end{array}$ \\
\hline haloxytop-methy & $69806-40-2$ & $5.00 E-05$ & & & & $3.01 E+00 \mathrm{n}$ \\
\hline hamony & $79277-27-3$ & $1.30 E-02$ & & & & $1.02 E+03 n$ \\
\hline heptachlor & $76-44-8$ & $5.00 E-04$ & & $4.50 E+00$ & $4.50 E+00$ & $1.42 E-01 \mathrm{C}$ \\
\hline heptachlor epoxide & $1024-57-3$ & $1.30 E-05$ & & $9.10 E+00$ & $9.10 E+\infty 0$ & $7.02 E-02 \mathrm{C}$ \\
\hline heptenluoropropane, $1,1,1,2,3,3,3$ & $439-89-0$ & & & & & \\
\hline heptane, n- & $142-82-5$ & & & & & \\
\hline hexabromobenzene & $87-82-1$ & 2.00E-03 & & & & $1.56 \mathrm{E}+02 \mathrm{n}$ \\
\hline hexabromodiphenyl other & $36483-60-0$ & & & & & \\
\hline hexachiorobenzene & $118-74-1$ & 8.00E-04 & & $1.60 \mathrm{E}+00$ & $1.60 E+00$ & 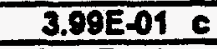 \\
\hline hexachlorobutadiene & $87-68-3$ & $2.00 E-04$ & & $7.80 E-02$ & $7.80 \mathrm{E}-02$ & $8.19 E+00 \mathrm{C}$ \\
\hline hexachlorocyclohexane, alpha- & $399-846$ & & & $6.30 E+00$ & $6.30 E+00$ & 1.01E-01 C \\
\hline hexachlorocyclohexane, beta & $319-85-7$ & & & $1.80 E+00$ & $1.80 E+00$ & 3.55E-01 C \\
\hline hexechlorocyclohexane, defta- & $319-86-8$ & & & & & \\
\hline hexachlorocyclohexane, epsilon- & $6108-10-7$ & & & & & \\
\hline hexachlorogyclohexane, gammo & $58-89-9$ & $3.00 E-04$ & & $1.30 E+00$ & & A.81E-01 C \\
\hline hexachlorocyclohexane, technical & $608-73-9$ & & & $1.80 E+00$ & $1.80 E+00$ & 3.55E-01 C \\
\hline hexachlorocyclopentadiene & $77-474$ & $7.00 E-03$ & $2.00 \mathrm{E}-05$ & & & $5.48 E+02 n$ \\
\hline hexachlorodibenzo-p-dioxin & $19408-74-3$ & & & $6.20 E+03$ & & 1.03E-04 C \\
\hline hexachloroethane & $67-72-1$ & $1.00 E-03$ & & $1.40 E-02$ & $1.40 E-02$ & $4.56 E+01 C$ \\
\hline hexachlorophene & $70-30-4$ & $3.00 E-04$ & & & & $2.35 E+01 \quad n$ \\
\hline hexamethylene diamine & $124-09-4$ & & & & & \\
\hline hexane, $n$ - & $1110-54-3$ & $6.00 E-02$ & $5.71 E-02$ & & & $4.69 E+03 n$ \\
\hline hexanone, 2- & $591-78-6$ & & & & & \\
\hline hexazinone & $51235-04-2$ & $3.30 E-02$ & & & & $2.58 E+03 n$ \\
\hline$h m x$ & $2691-41-0$ & $5.00 E-02$ & & & & $3.91 E+03 n$ \\
\hline hydrazine & $302-01.2$ & & & $3.00 \mathrm{E}+00$ & $1.70 E+01$ & $2.13 E-01 \mathrm{C}$ \\
\hline hydrazine sulfate & $10034-93-2$ & & & $3.00 E+00$ & $1.70 E+01$ & 2.13E-01 C \\
\hline hydrazine, 1, 1-dimethy & $57-14-7$ & & & $2.60 E+00$ & $3.50 E+00$ & $2.46 E-01 C$ \\
\hline hydrazine, 1,2-diethy & $1615-80-1$ & & & & & \\
\hline hydrazine, 1,2-dimethy & $540.73-8$ & & & $3.70 E+01$ & & $1.73 E-02 \mathrm{C}$ \\
\hline hydrazine, 1,2-dipheny & $122-66-7$ & & & $8.00 E-01$ & $8.00 E-01$ & $7.08 E-01 \mathrm{C}$ \\
\hline hydrogen chloride & $7647-01-0$ & & $2.00 E-03$ & & & \\
\hline hydrogen cyanide & $74-90-8$ & $2.00 E-02$ & B.57E-0. & & & $9.56 E+03 n$ \\
\hline hydrogen sulfide & $7738-06-4$ & $3.00 E-03$ & $2.57 E-04$ & & & $2.35 E+02 n$ \\
\hline hydroquinone & $123-31-9$ & $4.00 E-02$ & & & & $3.13 E+03 n$ \\
\hline imazali & $35554-44-0$ & $1.30 E-02$ & & & & $1.02 E+03 n$ \\
\hline imazaguin & $8.1335-37-7$ & $2.50 \mathrm{E}-01$ & & & & $4.96 E+04 n$ \\
\hline indeno $(1,2,3$-cd)pyrene & $193-39-5$ & & & $7.30 E-01$ & & 8.75E-01 C \\
\hline iprodione & $36734-19-7$ & $4.00 E-02$ & & & & $3.13 E+03 n$ \\
\hline iron & $7439-89-6$ & & & & & $4.09 E+04 \quad 6$ \\
\hline isobuty alcon:: & $78-83-1$ & $3.00 E-01$ & & & & $2.35 E+04 n$ \\
\hline isophorone & $78-59-1$ & $2.00 E-01$ & & 9.50E-04 & & $6.72 E+02$ c \\
\hline isopropalin & $33820-53-0$ & $1.50 E-02$ & & & & $1.17 E+03 \mathrm{n}$ \\
\hline isopropyt methy phosphonic acid & $1832-54-8$ & $1.00 E-01$ & & & & $7.82 E+03 n$ \\
\hline isoxaben & $82558-50-7$ & $5.00 \mathrm{E}-02$ & & & & $3.91 E+03 \mathrm{n}$ \\
\hline bactofen & $77501-63-4$ & $2.00 E-03$ & & & & $1.56 E+02 n$ \\
\hline lactonitrile & $78-97-7$ & & & & & \\
\hline lead & $7439-92-1$ & & & & & $4.00 E+02 e$ \\
\hline imonene, $\alpha$ & $5989-27.5$ & & & & & \\
\hline hnuron & $330-55-2$ & $2.00 \mathrm{E}-03$ & & & & $1.56 E+02 n$ \\
\hline Iondax & $83055-99-6$ & 2.00E-01 & & & & $1.56 E+04 n$ \\
\hline malanonitnile & $709-77-3$ & $2.00 E-05$ & & & & $1.56 E+00 n$ \\
\hline
\end{tabular}

Shaded RTD and CPS values obtained from Region III Risk-Based Concentration Table, Fourth Quarter 1994.

$b=$ SRS background value

$c=$ Cancer Risk

$e=$ EPA Soil Screening Guidance (EPAV40/R-94/101, December 1994).

$n=$ Hazard index $\quad$ Page 8 


\begin{tabular}{|c|c|c|c|c|c|c|}
\hline $\begin{array}{c}\text { Appendix B } \\
\text { HBL's for Non Aqueous IDW } \\
\text { CHEMICAL NAME }\end{array}$ & CASRN & $\begin{array}{c}\text { RTDo } \\
\mathrm{mg} / \mathrm{kg} / \mathrm{day}\end{array}$ & $\begin{array}{c}\text { RdDi } \\
\text { mg/kg/day }\end{array}$ & $\begin{array}{c}\text { CPSo } \\
\text { kg-day/mo }\end{array}$ & $\begin{array}{c}\text { CPSi } \\
\text { kg-day/mg }\end{array}$ & $\begin{array}{l}\text { Health-Based } \\
\text { Limit } \\
\text { mo/kg }\end{array}$ \\
\hline malathion & $121-75-5$ & $2.00 E-02$ & & & & $9.56 E+03 n$ \\
\hline maleic anhydride & $108-31.6$ & $1.00 E-01$ & & & & $7.82 E+03 n$ \\
\hline maleic hydrazide & $123-33-1$ & $5.00 E-01$ & & & & $3.01 E+04 n$ \\
\hline mancozeb & $8018-01-7$ & $3.00 E-02$ & & & & $235 E+03 n$ \\
\hline manob & $12427-38-2$ & $5.00 E-03$ & & & & $3.01 E+02 n$ \\
\hline manganese (food) & $7439-96-5$ & $1.40 E-01$ & 1.43E-05 & & & $1.10 E+04 n$ \\
\hline manganese (water) & $7439-96-5$ & $5.00 E-03$ & $1.43 E-05$ & & & $3.91 E+02 n$ \\
\hline mephosfolan & $950-10-7$ & $9.00 E-05$ & & & & $7.04 \mathrm{E}+00 \mathrm{n}$ \\
\hline mepiquat chloride & $24307.26-4$ & $3.00 E-02$ & & & & $2.35 E+03 n$ \\
\hline mercuric chloride & $7487.94-7$ & & & & & \\
\hline mercuny & $743997-6$ & 3.00E-04 & 8.57E-05 & & & $2.35 E+01 \quad n$ \\
\hline merphos & $150-50-5$ & $3.00 E-05$ & & & & $2.35 E+\infty 0 n$ \\
\hline merphos oxide & $78-48-8$ & $3.00 E-05$ & & & & $2.35 E+\infty 0 \mathrm{n}$ \\
\hline metalaxy & $57837-19-1$ & $6.00 E-02$ & & & & $4.69 E+03 n$ \\
\hline methacryiate, 2-ethoxyethy & $2370-63-0$ & & & & & \\
\hline methacndate, ethy & $97-63-2$ & 9.00E-02 & & & & $7.04 E+03 n$ \\
\hline methacryonitrile & $126-98-7$ & $1.00 E-04$ & $2.00 E-04$ & & & $7.82 E+00 n$ \\
\hline methamidiphos & $10265-92-6$ & 5.00E-05 & & & & $3.91 E+00 \mathrm{n}$ \\
\hline methanol & $67-56-1$ & $5.00 E-01$ & & & & $3.01 E+04 \mathrm{n}$ \\
\hline methidathion & 950.37 .8 & $1.00 E-03$ & & & & $7.82 E+01 n$ \\
\hline methomy & $16752-77-5$ & $2.50 \mathrm{E}-02$ & & & & $1.96 \mathrm{E}+03 \mathrm{n}$ \\
\hline methoxychlor & $72-43-5$ & $5.00 E-03$ & & & & $3.21 E+02 n$ \\
\hline methoxyethanol acetate, 2 - & $110-49-6$ & $2.00 \mathrm{E}-03$ & & & & $1.56 \mathrm{E}+02 \mathrm{n}$ \\
\hline methoxyethanol, 2- & $109-86-4$ & $1.00 E-03$ & 5.71E-03 & & & $7.82 E+01 n$ \\
\hline methyl acetate & $79-20-9$ & $1.00 E+00$ & & & & $7.82 E+04 n$ \\
\hline methyl acrylate & 9 & $3.00 E-02$ & & & & $2.35 E+03 n$ \\
\hline methyl chlorocarbonate & $79-22-1$ & & & & & \\
\hline methyl ethyl ketone peroxide & $1338.23-4$ & & & & & \\
\hline methyl hydrazine & $60-344$ & & & $1.10 E+00$ & & 5.81E-01 C \\
\hline methy iodide & $77-88-4$ & & & & & \\
\hline methyl isocyanate & $624-83-9$ & & & & & \\
\hline methyl mercury & $22967-92-6$ & $3.00 E-0.4$ & & & & $2.35 E+01 n$ \\
\hline methyl methacryate & $80-62-6$ & $8.00 E-02$ & & & & $6.26 E+03 n$ \\
\hline methyl parathion & $298-000$ & $2.50 E-04$ & & & & $1.26 E+01 n$ \\
\hline methyl styrene & $25013-15-4$ & $6.00 E-03$ & $1.14 E-02$ & & & $4.69 E+02 n$ \\
\hline methy siyrene, alpha & $98-83-9$ & $7.00 \mathrm{E}-02$ & & & & $5.48 E+03 n$ \\
\hline methyl tert-butyl ether (MTBE) & $1634-044$ & & $8.57 E-01$ & & & \\
\hline methylaniline hydrochloride, 2 - & $636-24-5$ & & & $1.80 E-01$ & & $3.55 E+00 \mathrm{C}$ \\
\hline methylaniline, 2- & $95-53-4$ & & & $2.40 E-01$ & & $2.66 E+00 \quad c$ \\
\hline methyicholanthracene. 3- & $56-49-5$ & & & & & \\
\hline methylcyclohexane & $108-87-2$ & & $8.57 E-01$ & & & \\
\hline methyiene bromide & $74-95-3$ & $1.00 E-02$ & & & & $7.82 E+02 n$ \\
\hline methylene chloride & $775-09-2$ & $6.00 \mathrm{E}-02$ & $8.57 E-01$ & $7.50 \mathrm{E}-03$ & $1.60 E-03$ & $8.52 E+01 c$ \\
\hline methylene-bis(2-chloroaniline), $4,4^{\prime}$ & $101-14-4$ & $7.00 E-04$ & & $1.30 E-01$ & $1.30 E-01$ & $4.81 E+00 \mathrm{c}$ \\
\hline methylene-bis (N,N-dimethy)aniline, $4,4^{\prime}-$ & $101-61.1$ & & & $4.60 E-02$ & & $1.39 E+04 \mathrm{C}$ \\
\hline methylenebisbenzenamine, 4,4:- & 101.77 .9 & & & 2.50501 & & $2.55 E+00 \mathrm{c}$ \\
\hline methylenediphenyl isocyanate, $4,4:$ & $101-68-8$ & & 5.71E-06 & & & \\
\hline methyinittosourea & $684-93-5$ & & & & & \\
\hline methyiphenol, 2- & $195-48-7$ & 5.00E-02 & & & & $3.91 E+03 n$ \\
\hline methyiphenol, 3 & $108-39-4$ & $5.00 E-02$ & & & & $3.91 E+03 n$ \\
\hline methyiphenol, 4- & $106-44-5$ & $5.00 E-03$ & & & & $3.91 E+02 n$ \\
\hline metolachlor & $51218-45-2$ & $1.50 E-01$ & & & & $1.17 E+04 n$ \\
\hline
\end{tabular}

Shaded RDD and CPS values obtained from Region III Risk-Based Concentration Table, Fourth Quarter 1994.

$b=$ SRS background value

$c=$ Cancer Risk

$e=$ EPA Soil Screening Guidance (EPA540/R-94/101. December 1994).

$n=$ Hazaro index

Page 9 


\begin{tabular}{|c|c|c|c|c|c|c|}
\hline $\begin{array}{l}\text { Appendix B } \\
\text { HBL's for Non Aqueous IDW } \\
\text { CHEMICAL NAME }\end{array}$ & CASRN & $\begin{array}{c}\text { RoDo } \\
\text { mo/kg/day }\end{array}$ & $\begin{array}{c}\text { RiDi } \\
\text { mg/kg/day }\end{array}$ & $\begin{array}{c}\text { CPSo } \\
\text { kg-day/mg }\end{array}$ & $\begin{array}{c}\text { CPSi } \\
\mathrm{kg-day} / \mathrm{mg}\end{array}$ & $\begin{array}{l}\text { Heaith-Based } \\
\text { Limit } \\
\text { molkg }\end{array}$ \\
\hline metribuzin & $21087-64-9$ & $2.50 \leq-02$ & & & & $1.96 E+03 n$ \\
\hline mirex & $2385-85-5$ & $2.005-04$ & & WhEKa & & $3.55 E-01 \mathrm{C}$ \\
\hline molinate & $2212-67-1$ & $2.00 E-03$ & & & & $1.55 E+02 n$ \\
\hline molybdenum & $7439-98-7$ & $5.00 E-03$ & & & & $3.01 E+02 n$ \\
\hline monochloramine & $10599-90-3$ & $1.00 E-01$ & & & & $7.82 E+03 n$ \\
\hline naled & $300-76-5$ & $2.00 \leq-03$ & & & & $1.565+02 n$ \\
\hline naphthalene & $91-20-3$ & & & & & \\
\hline naphthol hydrochloride, 1-emino-2- & $1198-27-2$ & & & & & \\
\hline naphthol, 1-amino-2- & $2834-826$ & & & & & \\
\hline naphthoguinone, 1,4 & $130-15-4$ & & & & & \\
\hline nepropamide & $1529999-7$ & $1,00 E-01$ & & & & $7.82 \mathrm{E}+03 \mathrm{n}$ \\
\hline niagra blue $4 B$ & $242974-5$ & & & & & \\
\hline nickel & $7440-02-0$ & $2.00 E-02$ & & & & $1.60 E+03=$ \\
\hline nickel carbony & $13463-39-3$ & & & & & \\
\hline nickel cyanide & $557-12-7$ & & & & & \\
\hline nickel refinery dust & NO CASRN & & & & $8.40 E-01$ & \\
\hline nickel subsulfide & $12035-72-2$ & & & & $1.70 E+00$ & \\
\hline nicotinonitrile & $100-54-9$ & & & & & \\
\hline nitrapyin & $1928-82-4$ & & & & & \\
\hline nitrate & $14797-55-8$ & $1.60 E+00$ & & & & $1.25 E+05 n$ \\
\hline nitric oxide & $10102-43-9$ & $1.00 E-01$ & & & & $7.82 E+03 n$ \\
\hline nitrite & $14797-65-0$ & $1.00 E-01$ & & & & $7.82 E+03 n$ \\
\hline nitroaniline, 2-methoxy-5- & $99-59-2$ & & & $4.60 E-02$ & & $1.39 E+01 \mathrm{C}$ \\
\hline nitroaniline, 2-methys-5- & $99-55-8$ & & & $3.30 E-02$ & & $1.84 E+01 \mathrm{C}$ \\
\hline nitroaniline, $m$ - & $99-09-2$ & & & & & \\
\hline nitroaniline, 0 - & $88-74-4$ & & 5.71E-05 & & & \\
\hline nitroaniline, $p$ - & $100-016$ & & & & & \\
\hline nitrobenzene & $88-95-3$ & 5.00E-04 & $5.71 E-04$ & & & $3.21 E+01 n$ \\
\hline nitrofurantoin & $67-20-9$ & $7.00 E-02$ & & & & $5.48 E+03 n$ \\
\hline nitsofurazone & $59-87-0$ & & & $1.50 E+00$ & & $4.26 E 01 \mathrm{C}$ \\
\hline nitrogen dioxide & $10102-44-0$ & $1.00 E+00$ & & & & $7.82 E+04 n$ \\
\hline nitroguanidine & $556-88-7$ & $1.00 E-01$ & & & & $7.82 E+03 n$ \\
\hline nitromethane & $75-52-5$ & & & & & \\
\hline nitsosodiethanolamine, $\mathrm{N}$ - & $1116-54-7$ & & & $2.80 E+00$ & & $228 E 01 \mathrm{C}$ \\
\hline nitrosodiethylamine, $\mathrm{N}$ - & $55-18-5$ & & & $1.50 E+02$ & $1.50 \mathrm{E}+02$ & $4.26 E-03 c$ \\
\hline nitrosodimethylamine, $\mathrm{N}$ - & $62-75-9$ & & & $5.10 E+01$ & $5.10 E+01$ & $1.25 \mathrm{E}-02 \mathrm{C}$ \\
\hline nitrosodiphenylamine, $\mathrm{p}$ - & $156-10-5$ & & & & & \\
\hline nitrosomethyiethylamine, $\mathrm{N}$ - & $10595-95-6$ & & & $2.20 E+01$ & & $2.00 \mathrm{E}-02 \mathrm{C}$ \\
\hline nitrosomethytvinyamine, $\mathrm{N}$ - & $4549-40-0$ & & & & & \\
\hline nitrosopytrolidine, $\mathrm{N}$ - & $930-55-2$ & & & $2.10 E+00$ & $2.10 E+00$ & 3.04E-01 C \\
\hline nitrotoluene, $\mathrm{m}$ - & 99-08-1 & $1.00 E-02$ & & & & $7.82 \mathrm{E}+02 \mathrm{n}$ \\
\hline introtoluene, o- & $88-72-2$ & $1.00 E-02$ & & & & $7.82 E+02 n$ \\
\hline nittotoluene, $p$ & $99-990$ & $1.00 E-02$ & & & & $7.82 \mathrm{E}+02 \mathrm{n}$ \\
\hline nomurazon & $27314-13-2$ & $4.00 E-02$ & & & & $3.13 E+03 n$ \\
\hline nustar & $85509-19-9$ & $7,00 E-04$ & & & & $5.48 E+01 n$ \\
\hline octabromodiphenvi ether & $32536.52-0$ & $3.00 E-03$ & & & & $2.35 E+02 n$ \\
\hline octamethypyrophosphoramide & $152-16-9$ & $2.00 E-03$ & & & & $1.56 \mathrm{E}+02 \mathrm{n}$ \\
\hline onzalin & $19044-88-3$ & $5.00 E-02$ & & & & $3.81 E+03 n$ \\
\hline osmium tetroxide & $20816-12-0$ & & & & & \\
\hline oxadiazon & $19666-30-9$ & 5.00E-03 & & & & $3.81 E+02 n$ \\
\hline oxamy & $23135-22-0$ & $2.50 E-02$ & & & & $1.06 E+03 n$ \\
\hline oxyluorfen & $42874-03-3$ & $3.00 E-03$ & & & & $2.35 E+02 n$ \\
\hline
\end{tabular}

Shaded RTD and CPS values obtained from Region III Risk-Based Concentration Table. Fourth Ouarter 1994.

$b=$ SRS background value

$c=$ Cancer Risk

$e=$ EPA Soil Screening Guidance (EPA540/R-94/101. December 1994).

$n=$ Hazard index

Page 10 


\begin{tabular}{|c|c|c|c|c|c|c|}
\hline $\begin{array}{c}\text { Appendix B } \\
\text { HBL's for Non Aqueous IDW } \\
\text { CHEMICAL NAME }\end{array}$ & CASRN & $\begin{array}{c}\text { RDDo } \\
\text { mg/kg/day }\end{array}$ & $\begin{array}{c}\text { RIDi } \\
\text { mgkg/day }\end{array}$ & $\begin{array}{c}\text { CPSo } \\
\text { kg-day/mg }\end{array}$ & $\begin{array}{c}\text { CPSi } \\
\text { kg-day/mg }\end{array}$ & $\begin{array}{l}\text { Health-Based } \\
\text { Limit } \\
\text { mg/kg }\end{array}$ \\
\hline azone & $10028-15-6$ & & & & & \\
\hline pactobutrazol & $76738-62-0$ & $1.30 E-02$ & & & & $1.02 E+03 n$ \\
\hline paraldehyde & $123-63-7$ & & & & & \\
\hline paraquat & $1910-42-5$ & $4.50 E-03$ & & & & $3.52 E+02 \mathrm{n}$ \\
\hline parathion & $56-38-2$ & $6.00 E-03$ & & & & $4.60 E+02 n$ \\
\hline pobulate & $1114-71-2$ & $5.00 E-02$ & & & & $3.01 E+03 n$ \\
\hline pendimethalin & $40487-42-1$ & $4.00 E-02$ & & & & $3.13 E+03 \mathrm{n}$ \\
\hline pentabromodipheny ether & $32534-81-9$ & $2.00 E-03$ & & & & $1.56 E+02 n$ \\
\hline pentachlorobenzene & $608-93-5$ & $8.00 E-04$ & & & & $6.26 E+04 \mathrm{n}$ \\
\hline pentachlorocyclopentadiene & $25329-35-5$ & & & & & \\
\hline pentachloronitrobenzene & $82-68-8$ & $3.00 E-03$ & & $2.60 E-01$ & & $2.46 E+\infty \quad c$ \\
\hline pentachlorophend & $87-86-5$ & $3.00 E-02$ & & $1.20 E-01$ & & $5.32 E+00 \mathrm{C}$ \\
\hline pentachloropropene, $1,1,2,3,3$ & $1600-37-9$ & & & & & \\
\hline Pentone, $n$ - & $109-66-0$ & & & & & \\
\hline pentenone, 4-methy-2- & $108-10-1$ & $8.00 E-02$ & $2.29 E-02$ & & & $6.26 E+03 n$ \\
\hline perfluorobutane & $355-25-9$ & & & & & \\
\hline periluoroethane & $354-33-6$ & & & & & \\
\hline pertuorohexane & $355-42-0$ & & & & & \\
\hline permethrin & $52645-53-1$ & $5.00 E-02$ & & & & $3.81 E+03 n$ \\
\hline phenanthrene & $85-01-8$ & & & & & \\
\hline phenmedipham & $13684-63-4$ & 2.50E-01 & & & & $1.96 E+04 n$ \\
\hline phenol & $108-95-2$ & 6.00E-01 & & & & $4.69 E+04 \mathrm{n}$ \\
\hline phenol, 2,3,4-trichloro & $15950-66-0$ & & & & & \\
\hline phenol, 2,3,5-trichloro & $933-78-8$ & & & & & \\
\hline phenol, 2,3,6-trichloro & $933-75-5$ & & & & & \\
\hline phenol, 2,3-dimethy & $526-75-0$ & & & & & \\
\hline phenol, 2,3-dinitro & $66-56-8$ & & & & & \\
\hline phenol, 2,4,5-trichloro & $95-95-4$ & $1.00 E-01$ & & & & $7.82 E+03 n$ \\
\hline phenol, 2,4,6-trichioro & $88-06-2$ & & & $1.10 E-02$ & $1.00 E-02$ & $5.81 E+01 c$ \\
\hline phenol, 2.4-dimethyl & $105-67-9$ & $2.00 E-02$ & & & & $1.56 E+03 n$ \\
\hline phenol, 2,4-dinitro & $51-28-5$ & 2.00E-03 & & & & $1.56 E+02 n$ \\
\hline phenol, 2,5-dimethyl & $95-87-4$ & & & & & \\
\hline phenol, 2.5-dinitro & $329-71.5$ & & & & & \\
\hline phenol, 2,6-dimethy & $576-26-1$ & $6.00 E-04$ & & & & $4.69 E+01 n$ \\
\hline phenol, 2,6-dinitro & $573-56-8$ & & & & & \\
\hline phenol. 2-chloro & $95-57-8$ & $5.00 \mathrm{E}-03$ & & & & $3.81 E+02 n$ \\
\hline phenol, 3,4.5-trichloro & $609-19-8$ & & & & & \\
\hline phenol, 3,4-dimethyl & $95-65-8$ & $1.00 E-03$ & & & & $7.82 E+04 n$ \\
\hline phenol, 3.5-dinitro & $586-11-8$ & & & & & \\
\hline phenol. 3-chioro & $108-43-0$ & & & & & \\
\hline phenol, 4,6-dinitro-o-cyclohexy & $131-89.5$ & $2.00 \mathrm{E}-03$ & & & & $1.56 E+02 n$ \\
\hline phenol, 4-chloro & $106-48-9$ & & & & & \\
\hline phenol, m-amino & 591.27 .5 & $7.00 \mathrm{E}-02$ & & & & $5.48 E+03 n$ \\
\hline phenol, o-amino & $95-55-6$ & & & & & \\
\hline phenol, p-amino & $123-30-8$ & & & & & \\
\hline phenol, p-nitro & $100-02-7$ & & & & & \\
\hline phenylenediamine, $m$ - & $108-45-2$ & 6.00E-03 & & & & $4.69 E+02 n$ \\
\hline Dhenylenediamine, a & $95-54-5$ & & & $4.70 E-02$ & & $1.36 E+01 \mathrm{c}$ \\
\hline phenylenediamine, p & $106-50-3$ & $1.90 \mathrm{E}-01$ & & & & $9.49 E+04 n$ \\
\hline phenyimercuric acetate & $62-38-4$ & $8.00 E-05$ & & & & $6.26 E+\infty 0 n$ \\
\hline phenyiphenol, 2- & $90-43-7$ & & & $1.94 E-03$ & & $3.28 E+02 c$ \\
\hline phorate & $1298-02-2$ & $2.00 E-04$ & & & & $1.56 E+01 n$ \\
\hline
\end{tabular}

Shaded RTD and CPS values obtained from Region III Risk-Based Concentration Table. Fourth Quarter 1994.

$b=S R S$ background value

$c=$ Cancer Risk

e = EPA Soil Screening Guidance (EPA540/R-94/101, December 1994)

$n=$ Hazard index

Page 19 


\begin{tabular}{|c|c|c|c|c|c|c|}
\hline $\begin{array}{c}\text { Appendix B } \\
\text { HBL's for Non-Aqueous low } \\
\text { CHEMICAL NAME }\end{array}$ & CASRN & $\begin{array}{c}\text { RiDo } \\
\text { mo/kg/day }\end{array}$ & $\begin{array}{c}\text { RiDi } \\
\text { mg/kg/day }\end{array}$ & $\begin{array}{c}\text { CPSo } \\
\text { ko-dayfmo }\end{array}$ & $\begin{array}{c}\text { CPSi } \\
\mathrm{kg} \text {-day/mo }\end{array}$ & $\begin{array}{l}\text { Hoalth-Based } \\
\text { Lmik } \\
\text { monkg }\end{array}$ \\
\hline phosalone & $2310-17-0$ & & & & & \\
\hline phosgene & $75-44-5$ & & & & & \\
\hline phosmet & $732-11-6$ & 2.00E-02 & & & & $1.36 E+03 n$ \\
\hline phosphate, diethyl-p-nitopheny & $311-45-5$ & & & & & \\
\hline phosphine & $7803-51-2$ & $3.00 E-04$ & B.57E-0. & & & 235E+01 $n$ \\
\hline phosphons & $7723-140$ & 2.00E.05 & & & & $1.56 \mathrm{E}+00 \mathrm{n}$ \\
\hline phthalate, Nbutubensy & $85-68-7$ & $2.00 E-01$ & & & & $1.56 E+04 n$ \\
\hline phthalate, bis(2-ethylhex) & $117-81-7$ & 2.00E-02 & & $1.405-02$ & & $4.56 E+01 \mathrm{e}$ \\
\hline phthalate din-but & $84-742$ & $1.00 E-01$ & & & & $7.82 E+03 n$ \\
\hline phthalate, din-octyt & $117-84-0$ & 2.00E-02 & & & & $1.56 E+03 n$ \\
\hline phthalate dimethy & $131-11-3$ & $1.00 E+01$ & & & & $7.82 E+05 n$ \\
\hline phthalate, dimethytere & $120-61-6$ & $1.00 E-01$ & & & & $7.82 E+03 n$ \\
\hline phthalic acid $m$. & $121-91-5$ & & & & & \\
\hline Dhthalic ecid, o- & $88-82-3$ & & & & & \\
\hline phthalic acid, $p$ & $100-21-0$ & $1.00 E+00$ & & & & $7.82 \mathrm{E}+04 \mathrm{n}$ \\
\hline phthalic anhydride & $85-449$ & $2.00 E+00$ & $3.43 E-02$ & & & $1.56 E+05 n$ \\
\hline picloram & $1918-02-1$ & $7.00 E-02$ & & & & $5.46 E+03 n$ \\
\hline pinene, alphs & $80-56-8$ & & & & & \\
\hline pinene, beta- & $127-91.3$ & & & & & \\
\hline pirimiphos-methy & $29232-83-7$ & $1.00 E-02$ & & & & $7.82 E+02 \mathrm{n}$ \\
\hline polybrominated biphenyts & NO CASRN & $7.00 E-06$ & & $8.90 E+00$ & & $7.18 E-02 \mathrm{C}$ \\
\hline polychlorinated biphenyts (PCBs) & $1336-36-3$ & & & $7.70 E+00$ & & $8.30 E 02 c$ \\
\hline polyoyclic organic matter (POM) & NOCASRN & & & & & \\
\hline potassium bromete & $7758-01-2$ & & & & & \\
\hline potassium Granide & $151-50-8$ & 5.00E-02 & & & & $3.01 E+03 n$ \\
\hline potassium siver cranide & $506-61-6$ & $2.00 E-01$ & & & & $1.56 E+04 n$ \\
\hline prochlorez & $67747-085$ & 9.00E-03 & & 1.50E-01 & & $4.26 E+00 e$ \\
\hline profluralin & $26399-36-0$ & 6.00E-03 & & & & $4.69 E+02 \mathrm{n}$ \\
\hline prometon & $1610-18-0$ & $1.50 E-02$ & & & & $1.17 E+03 n$ \\
\hline prometryn & 7287.196 & $4.00 E-03$ & & & & $3.13 E+02 n$ \\
\hline pronamide & $23950-58-5$ & $7.50 E-02$ & & & & $5.87 E+03 n$ \\
\hline propachlor & $1918-16-7$ & $1.30 E-02$ & & & & $1.02 E+03 n$ \\
\hline propane, 2-chloro & $75-29-6$ & & 2.86E-02 & & & \\
\hline propane, 2-nitro & $79-46-9$ & & $5.71 E-03$ & & $9.40 E+00$ & \\
\hline propanil & $709-98-8$ & 5.00E-03 & & & & $3.91 E+02 n$ \\
\hline propargite & $2312.35-8$ & $2.00 E-02$ & & & & $1.56 E+03 n$ \\
\hline propargy alcohol & $107-19-7$ & $2.00 E-03$ & & & & $1.56 \mathrm{E}+02 \mathrm{n}$ \\
\hline propazine & $139-40-2$ & 2.00E-02 & & & & $1.56 E+03 n$ \\
\hline propham & $122-42-9$ & 2.00E-02 & & & & $1.56 E+03 n$ \\
\hline propiconazole & $60207-90-1$ & $1.30 \mathrm{E}-02$ & & & & $1.02 E+03 \mathrm{n}$ \\
\hline propiolactone beta- & $57-57-8$ & & & & & \\
\hline propionic acid, $2(2,4,5$-trichlorophenoxy) & $93-72-1$ & $8.00 E-03$ & & & & $6.26 E+02 n$ \\
\hline propionic acid $2-(2$-methy-4-chlorophenoxy) & $93-65-2$ & 1.00E-03 & & & & $7.82 E+01 n$ \\
\hline propionitrile & $107-12-0$ & & & & & \\
\hline propy alcohol, $n$ & $71.23-8$ & & & & & \\
\hline propyene ghycol & 57.556 & $2.00 E+01$ & & & & $1.56 E+06 n$ \\
\hline propyene oxide & $75-56-9$ & & 8.57E-03 & $2.40 E-01$ & $1.30 E-02$ & $2.66 E+00 c$ \\
\hline propyeneimine & $75-55-8$ & & & & & \\
\hline pursun & $81335-77.5$ & $2.50 E-01$ & & & & $1.06 E+04 n$ \\
\hline gydrin & $51630-58-1$ & $2.50 E-02$ & & & & $1.96 \mathrm{E}+03 \mathrm{n}$ \\
\hline Prene & $129-00-0$ & 3.00E-02 & & & & $2.35 E+03 n$ \\
\hline Pridine & $110-86-1$ & $1.00 E-03$ & & & & $7.82 E+01 n$ \\
\hline
\end{tabular}

Shaded RTD and CPS values obtained from Region III Risk-Based Concentation Table, Fourth Quarter 1994.

$b=$ SRS background value

$c=$ Cancel Risk

e = EPA Soil Screening Guidance (EPA540/R-94/101. December 1994)

$n=$ Hazard Index

Page 12 


\begin{tabular}{|c|c|c|c|c|c|c|}
\hline $\begin{array}{c}\text { Appendix B } \\
\text { HBL's for Non-Aqueous IDW } \\
\text { CHEMICAL NAME }\end{array}$ & CASRN & $\begin{array}{c}\text { RiDo } \\
\text { molko/day }\end{array}$ & $\begin{array}{c}\text { RrDi } \\
\text { mo/kg/day }\end{array}$ & $\begin{array}{c}\text { CPSo } \\
\text { kg-day/mg }\end{array}$ & $\begin{array}{c}\text { CPSi } \\
\text { ko-day/mo }\end{array}$ & $\begin{array}{c}\text { Health-Based } \\
\text { Limit } \\
\text { mg/kg }\end{array}$ \\
\hline Pyridine, 4-amino & $504-245$ & $2.00 E-05$ & & & & $1.56 \mathrm{E}+00 \mathrm{n}$ \\
\hline quinalphos & $13593-03-8$ & $5.00 E-04$ & & & & $3.01 E+01 n$ \\
\hline quinoline & $01-22-5$ & & & $1.20 E+01$ & & $5.32 E-02 \mathrm{C}$ \\
\hline quinone & $106-514$ & & & & & \\
\hline roto & $121-824$ & $3.00 E-03$ & & $1.10 E-01$ & & $5.81 E+00 \mathrm{c}$ \\
\hline refractory ceramic fibere & NO CASRN & & & & & \\
\hline resmethin & $10453-86-8$ & 3.00E-02 & & & & $2.35 E+03 n$ \\
\hline ronnel & $299-84-3$ & 5.00E-02 & & & & $3.01 E+03 n$ \\
\hline rotenone & $83-724$ & $4.00 E-03$ & & & & $3.13 E+02 n$ \\
\hline savey & $78587-05-0$ & $2.50 E-02$ & & & & $1.98 E+03 n$ \\
\hline Eelonious acid & $7783-00-8$ & $5.005-03$ & & & & $3.81 E+02 n$ \\
\hline selenium & $7782-19-2$ & $5.00 E-03$ & & & & $3.01 E+02 n$ \\
\hline selenium sulinde & $7446-346$ & & & & & \\
\hline selenourea & $630-10-4$ & $5.00 E-03$ & & & & $3.21 E+02 n$ \\
\hline eethoxydim & $7405180-2$ & $9.00 \mathrm{E}-02$ & & & & $7.04 E+03 n$ \\
\hline E'ver & $7440-224$ & $5.00 E-03$ & & & & $3.01 E+02 n$ \\
\hline siver cyanide & $506-64-9$ & $1.00 E-01$ & & & & $7.82 E+03 n$ \\
\hline exmazine & $122-34-9$ & 5.00E-03 & & $1.20 E-01$ & & $5.32 E+00 \mathrm{C}$ \\
\hline sodium asjide & $26628-22-8$ & $4.00 E-03$ & & & & $3.13 E+02 n$ \\
\hline sodium gyanide & $143-33.9$ & $4.00 E-02$ & & & & $3.13 E+03 n$ \\
\hline sodium diethyldithiocarbamate & $148-18-5$ & $3.00 E-02$ & & 2.70E-01 & & $2.37 E+\infty 0 \mathrm{C}$ \\
\hline sodium fivoroacetate & $62.74-8$ & $2.00 E-05$ & & & & $9.56 \mathrm{E}+00 \mathrm{n}$ \\
\hline sodium metavanadate & $13718-26-8$ & $1.00 E-03$ & & & & $7.82 E+04 n$ \\
\hline strontium & $7740-24-6$ & 6.00E-01 & & & & $4.60 E+04 \mathrm{n}$ \\
\hline strychnine & $57.24-9$ & $3.00 E-00$ & & & & $235 E+01 n$ \\
\hline styrene & $100-42.5$ & $2.00 E-01$ & $2.86 E-01$ & & & $1.56 E+04 n$ \\
\hline succinonitrile & $110-81-2$ & & & & & \\
\hline suliate, dimethy & $77.78-1$ & & & & & \\
\hline sulfide, p-chlorophenyl methyl & $123-08-1$ & & & & & \\
\hline cultone, p-chioropheny methy & 98.57 .7 & & & & & \\
\hline sulfoxide, p-chloropheny methy & $934-73.6$ & & & & & \\
\hline Eulfuric acid & $7664-93-9$ & & $2.00 E-02$ & & & \\
\hline systhane & $88761-89-0$ & $2.50 E-02$ & & & & $1.06 E+03 n$ \\
\hline tebuthiuron & $34014-18-1$ & $7.00 E-02$ & & & & $5.48 E+03 n$ \\
\hline temephos & $3383-96-8$ & $2.00 E-02$ & & & & $1.56 E+03 n$ \\
\hline terbacil & 5902.51 .2 & $1.30 E-02$ & & & & $1.02 E+03 n$ \\
\hline terbufos & $13071.70-9$ & $2.50 E-05$ & & & & $1.96 \mathrm{E}+00 \mathrm{n}$ \\
\hline terbutryn & $886-50-0$ & $1.00 E-03$ & & & & $7.82 E+01 n$ \\
\hline tetrabromodiphenyl ether & $40088-47-9$ & & & & & \\
\hline Ietrachloroazoxybenzene & 12123247.3 & & & & & \\
\hline tetrachlorobenzene, $1,2,4,5$ & $95-94-3$ & $3.00 \mathrm{E}-04$ & & & & $235 E+09 n$ \\
\hline tetrachlorosyclopentadiene & $695-77-2$ & & & & & \\
\hline tetrachloroethane, $1,1,1,2$ & $630-20-6$ & $3.00 E-02$ & & $2.60 E-02$ & $2.60 E-02$ & $2.46 E+01 c$ \\
\hline tetrachioroethane, $1,1,2,2$ & $779-34.5$ & & & $2.00 E-01$ & $2.00 E-01$ & $3.10 E+00 \quad \mathrm{c}$ \\
\hline tetrachloroethene (PCE) & $\longdiv { 1 2 7 . 1 8 4 }$ & $1.00 E-02$ & & $5.20 E-02$ & $2.00 E-03$ & $1.23 E+01 \mathrm{C}$ \\
\hline Letrachlorohydrazobenzene & $71753-42-9$ & & & & & \\
\hline retrachlorophenol, 2,3,4,5- & $4901-51.3$ & & & & & \\
\hline tetrachlorophenol, 2,3,4,6- & $58-90-2$ & $3.00 E-02$ & & & & $2.35 E+03 n$ \\
\hline tetrachlorophenol, 2,3,5,6 & $935-95-5$ & & & & & \\
\hline tetrachloropropene, $1,1,2,3$ & $10436-39-2$ & & & & & \\
\hline tetrachlorotoluene, p, a, a, : & 5 & & & $2.00 E+01$ & & $3.10 E-02 \mathrm{C}$ \\
\hline tetrachlominphos & $1961-11.5$ & $3.00 E-02$ & & $240 E-02$ & & $2.66 E+09 c$ \\
\hline $\begin{array}{l}\text { Shaded RD and CPS values obtainec } \\
b=\text { SRS background value } \\
c=\text { Cancer Risk } \\
e=\text { EPA Soil Scroening Guidance (EP } \\
n=\text { Hazard Index }\end{array}$ & ent & pe 13 & & & & 2/13/9! \\
\hline
\end{tabular}




\begin{tabular}{|c|c|c|c|c|c|c|}
\hline $\begin{array}{c}\text { Appendix B } \\
\text { HBL's for Non-Aqueous IDW } \\
\text { CHEMICAL NAME }\end{array}$ & CASRN & $\begin{array}{c}R \text { RDo } \\
\text { mokg/day }\end{array}$ & $\begin{array}{c}\text { RrDi } \\
\text { molkolday }\end{array}$ & $\begin{array}{c}\text { CPSo } \\
k g-\text { day/mg }\end{array}$ & $\begin{array}{c}\text { CPSi } \\
\text { ko-day/mo }\end{array}$ & $\begin{array}{l}\text { Heafth-Based } \\
\text { Limit } \\
\text { monkg }\end{array}$ \\
\hline tetraethy dithiopyrophosphate & $3689-24-5$ & 5.00E $=0.1$ & & & & $3.91 E+01 n$ \\
\hline tetreathyllead & $78-00-2$ & $1.00 \mathrm{E}-07$ & & & & $7.82 E-03 n$ \\
\hline Thalic oxide & $1314-32-5$ & & & & & \\
\hline thalium & $7440-28-0$ & & & & & \\
\hline thelum (1) ocetate & $563.68-8$ & $9.00 E-05$ & & & & $7.04 E+\infty n$ \\
\hline tha um 0 carbonate & $6533-73-9$ & $8.00 E-05$ & & & & $6.26 E+\infty 00$ \\
\hline Ehalium (1) chloride & $7799-12-0$ & $8.00 E-05$ & & & & $6.26 E+\infty 0 n$ \\
\hline thallum (0) nitrete & $10102-45-1$ & $9.00 E-05$ & & & & $7.04 E+\infty n$ \\
\hline thalium (0) eulfate & $7446-18-6$ & $8.00 E-05$ & & & & $6.26 E+\infty 0 n$ \\
\hline tha fium selenite & $1203952-0$ & & & & & \\
\hline thiobencatb & $28249-776$ & 1.00E-02 & & & & $7.82 E+02 n$ \\
\hline thiofanox & $39196-18-4$ & $3.00 E-04$ & & & & $235 E+01 n$ \\
\hline thiophanato-methy & $23564-05-8$ & $8.00 E-02$ & & & & $6.26 E+03 n$ \\
\hline thiram & $137-26-8$ & $5.00 E-03$ & & & & $3.01 E+02 n$ \\
\hline in & $7440-31-5$ & 6.00E-01 & & & & $4.69 E+04 n$ \\
\hline toluene & $108-88-3$ & 2.00E-01 & 1.14E-01 & & & $1.56 E+04 n$ \\
\hline toluene disocyenate, 2,4 & NO CASRN & & & & & \\
\hline Solvene, 2,3-diamino & $2687-254$ & & & & & \\
\hline toluene, 2,3-dinituo & $602-01.7$ & & & & & \\
\hline Loluene, 2,4,6-trinituo & $118-96-7$ & 5.00E-O4 & & $3.00 E-02$ & & $213 E+01 \mathrm{C}$ \\
\hline toluene, 2,4-diamino & $95-80-7$ & & & $3.20 E+00$ & & $2.00 E-01 \mathrm{C}$ \\
\hline toluene, 2,4 -dinitro & 121.142 & $2.00 E-03$ & & $6.80 E-01$ & & Q.39E-01 C \\
\hline toluene, 2,5-diamino & $95-70-5$ & $6.00 E-01$ & & & & $4.69 E+04 n$ \\
\hline toluene, 2,5-dinitro & $610-15-8$ & & & & & \\
\hline toluene, 2,6-diamino & $823-40-5$ & 2.00E-01 & & & & $1.56 E+04 n$ \\
\hline toluene, 2,6-dinito & $600-20-2$ & $1.00 E-03$ & & 6.80E-01 & & $0.38 E-01 \mathrm{C}$ \\
\hline tolvene, 3,4-diamino & $496-72-0$ & & & & & \\
\hline toluene, 3,4 -dinitro & $610-390$ & & & & & \\
\hline toluene, m-chloro & $\longdiv { 1 0 8 - 1 9 - 8 }$ & & & & & \\
\hline toluene, m-ethy & $620-144$ & & & & & \\
\hline toluene, o-chloro & $95-49-8$ & $2.00 E-02$ & & & & $1.56 E+03 n$ \\
\hline toluene, o-ethy & $611-14-3$ & & & & & \\
\hline toluene, o-chloro & $106-434$ & & & & & \\
\hline toluene, p-thy & $622-96-8$ & & & & & \\
\hline toluidine, $m$ - & $108-44-1$ & & & & & \\
\hline toluidine, p & $106-490$ & & & $1.90 E-01$ & & $3.36 E+00 \mathrm{C}$ \\
\hline toxaphene & $8001-35-2$ & & & $9.10 E+00$ & $1.10 E+\infty 0$ & 5.81E01 C \\
\hline tralomethrin & $66849.25-6$ & $7.50 E-03$ & & & & $5.87 E+02 n$ \\
\hline triallate & $2303-17-5$ & $1.30 \mathrm{E}-02$ & & & & $1.02 E+03 n$ \\
\hline triasulfuron & $B 2097-50-5$ & $1.00 E-02$ & & & & $7.82 E+02 n$ \\
\hline triblomochloromethane & $594-15-0$ & & & & & \\
\hline tribromodipheny ether & $49690-24-0$ & & & & & \\
\hline troutyitin oxide & $56-35-9$ & $3.00 E-05$ & & & & $2.35 E+\infty n$ \\
\hline trichiorocyclopentadiene & $77323-84.3$ & & & & & \\
\hline tichloroethene (TCE) & 79016 & 6.00E-03 & & T,10E-02 & & $5.81 E+01 \mathrm{C}$ \\
\hline trichlorofluoromethane & $75-69-4$ & $3.00 E-01$ & $2.00 E-01$ & & & $2.35 E+04 n$ \\
\hline trichloropropane, 1,1,1- & $7789-899$ & & & & & \\
\hline thehloropropane, 1,1,2 & $598-776$ & $5.00 E-03$ & & & & $3.91 E+02 n$ \\
\hline trichloropropane, 1,2,2. & $3975-23-3$ & & & & & \\
\hline trichioropropane, $1,2,3$ & $96-18-4$ & $6.00 E-03$ & & $7.00 E+00$ & & $0.12 \mathrm{E}-02 \mathrm{C}$ \\
\hline trichioropropene, 1,2,3- & $96-19-5$ & $5.00 E-03$ & & & & $3.91 E+02 \mathrm{n}$ \\
\hline trichlorotoluene, $2,3,6$ & $207746-5$ & & & & & \\
\hline
\end{tabular}

Shaded RD and CPS values obtained from Region III Risk-Based Concentration Table, Fourth Quarter 1994.

$b=$ SRS background value

$c=$ Cancer Risk

$e=$ EPA Soil Screening Guidance (EPA540/R-94/101, Decembe: 1994)

$n=$ Hazard Index $\quad$ Page 14 
WSRC-RP-94-1227, Rev.

\begin{tabular}{|c|c|c|c|c|c|c|}
\hline $\begin{array}{l}\text { Appendix B } \\
\text { HBL's for Non-Aqueous IDW } \\
\text { CHEMICAL NAME }\end{array}$ & CASRN & $\begin{array}{c}\text { Rido } \\
\text { mokg/day }\end{array}$ & $\begin{array}{c}\text { Ridi } \\
\text { mo/kg/day }\end{array}$ & $\begin{array}{c}\text { CPSo } \\
\text { kg-dgy/mg }\end{array}$ & $\begin{array}{c}\text { CPSi } \\
\text { kg-day/mo }\end{array}$ & $\begin{array}{l}\text { Hoalth-Based } \\
\text { Umit } \\
\text { monkg }\end{array}$ \\
\hline trichlorotoluene, alpha,2,6- & $2014-83-7$ & & & & & \\
\hline tricresol & $1318-77.3$ & & & & & \\
\hline tridiphane & $58138-08-2$ & $3.00 E-03$ & & & & $2.35 E+02 n$ \\
\hline triethylamine & $\longdiv { 1 2 1 - 4 4 8 }$ & & $2.00 E-03$ & & & \\
\hline triluoroethane, 1,1,1- & $420-46-2$ & & & & & \\
\hline tilluoromethane & $75-46-7$ & & & & & \\
\hline trifuralin & $1582-09-8$ & $7.50 E-03$ & & $7.70 E-03$ & & $8.30 E+01 c$ \\
\hline trimethy phosphete & $512-56-1$ & & & $3.70 E-02$ & & $1.73 E+01 c$ \\
\hline trimethyipentane, 2,2,4 & $540-84-1$ & & & & & \\
\hline trintrophenyimethynitramine & $\longdiv { 4 7 2 - 4 5 - 8 }$ & $1.00 E-02$ & & & & $7.02 E+02 n$ \\
\hline urea, n,n-dimethy & $598-947$ & & & & & \\
\hline venadium & $7440-02-2$ & $7.005-03$ & & & & $5.50 \mathrm{E}+02$ \\
\hline vanadium pentoxide & $1314-62-1$ & $9.00 E-03$ & & & & $7.04 E+02 n$ \\
\hline vanadium sulfate & $36907-12-3$ & $2.00 E-02$ & & & & $9.56 E+03 n$ \\
\hline vernam & $1929-77.7$ & $1.00 E-03$ & & & & $7.82 E+01 n$ \\
\hline vinctozolin & $50471-44-8$ & $2.50 E-02$ & & & & $1.08 E+03 n$ \\
\hline viny acetate & $108-05-4$ & $1.00 E+00$ & $5.71 E-02$ & & & $7.82 E+04 n$ \\
\hline viny bromide (bromoethene) & $593-60-2$ & & 8.57E-04 & & $1.10 E-01$ & \\
\hline vinyl chloride & $75-014$ & & & $1.90 E+00$ & $3.00 E-01$ & $3.36 E 01 \mathrm{C}$ \\
\hline wartanin & 81.89 .2 & $3.00 E-04$ & & & & $2.35 E+01 n$ \\
\hline xyene, 4-ethyto- & $934-80-5$ & & & & & \\
\hline myene. $m$ - & $108-30-3$ & $2.00 E+00$ & & & & $1.56 E+05 \mathrm{n}$ \\
\hline xyiene, moxture & $1330-20-7$ & $2.00 E+\infty$ & & & & $7.56 E+05 n$ \\
\hline xylene, $a$ & $\longdiv { 9 5 - 4 7 . 6 }$ & $2.00 E+00$ & & & & $1.56 E+05 n$ \\
\hline xylene, $p$ & $106-42-3$ & & & & & \\
\hline Zine & $7440-66-6$ & $3.00 E-01$ & & & & $2.35 E+04 n$ \\
\hline Zinc cyanide & 557.21 .1 & $5.00 E-02$ & & & & $3.01 E+03 n$ \\
\hline zinc phosphide & $1314-84-7$ & $3.00 E-04$ & & & & $2.35 E+01 n$ \\
\hline zineb & $112122-67.7$ & $5.00 E-02$ & & & & $3.91 E+03 \mathrm{n}$ \\
\hline
\end{tabular}

Shaded RD and CPS values obtained from Region III Risk-Based Concentration Table. Fourth Quarter 1994

$b=$ SRS background value

$c=$ Cancer Risk

$e=$ EPA Soil Screening Guidance (EPA540/R-94/101, December 1994).

$n=$ Hazard Index

Page 15 


\begin{tabular}{|c|c|c|c|c|c|c|c|}
\hline \multicolumn{3}{|c|}{ 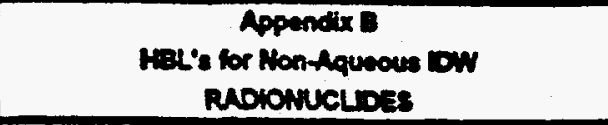 } & \multirow{2}{*}{$\begin{array}{l}\text { Hallils } \\
\text { (ones) }\end{array}$} & \multirow{2}{*}{$\begin{array}{c}\text { Risk-band } \\
\text { Pro } \\
\text { Lnw } \\
(R=E A) \\
(x-1)\end{array}$} & \multirow{2}{*}{ 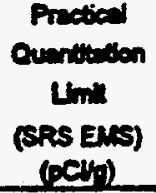 } & \multirow{2}{*}{ 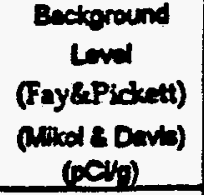 } & \multirow{2}{*}{$\begin{array}{l}\text { Dew } \\
\text { sereming } \\
\text { lewel } \\
\text { (peys) }\end{array}$} \\
\hline Enmont & chs: & belepes & & & & & \\
\hline neriestan & lo145eg-102 & $\mid a_{12} 21$ & $\Leftrightarrow$ & 23 & 2 & & 25 \\
\hline exten & $014762-75-5$ & c-14 & srop & 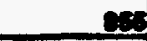 & 02 & & es: \\
\hline ceivm & $010045-07-3$ & Co-137 & $\boldsymbol{0}$ & 27 & 0.1 & a.245 & 2 \\
\hline $\cos n+D$ & $010045-27-31+01$ & $\cos 137+D$ & 30 & 00 & es & & 0.1 \\
\hline entit. & $010188-400$ & co-eo & 527 & 000 & at & & 0.1 \\
\hline oxim & lo13281.15-? & Cen-24 & 10.1 & 4 & 1 & & er \\
\hline arcoing & $014883-230$ & Fu162 & 132 & 0.01 & es. & & o.t. \\
\hline aresin & ors5es-10-1 & Ex-1se & ed & oed & $e 2$ & & e. \\
\hline custin & 014391.18 .3 & Furgs & 48 & 0.7 & 02 & & 0.7 \\
\hline hydresen is & $010020-17.8$ & 14 & 123 & 1424 & 6 & & 14245 \\
\hline Lextion & or5046-84-1 & L130 & $15 \pi \times 07$ & 29 & 1 & & 22 \\
\hline nepruningm & $013994-20-2$ & We-237 & $2.14 E+00$ & 2.1 & 1 & & 2.5 \\
\hline neptunium +D & $\mid 01399420-21+01$ & $\mathrm{No}-237+0$ & 2.14E+CS & 0.1 & 1 & & \\
\hline plutoninm & $013881-16-3$ & Aus23: & e7.7 & 25 & 1 & 0.000 & 3. \\
\hline glvionim & 015117.48 .3 & Pu-238 & $2.41 E+04$ & 32 & 1 & 0.018 & 3.2 \\
\hline otrontion & $010098-97.2$ & Ereco & 28.6 & 20 & 1 & 0.005 & 28 \\
\hline etromium +D & $\mid 010098-97.21+01$ & $\sec 2+0$ & 28.0 & 21 & 1 & & 21 \\
\hline tectinetivm & $014133-76-7$ & Tore & $2.13 \pm+05$ & 27 & 0.5 & & xi \\
\hline tharium: & $2007440-20-1$ & Th-232 & 1.41E+10 & 0 & 1 & 0.93 & 62 \\
\hline tharium $+D^{\circ}$ & $2007440-22-11+D I$ & Th-232 +D & 1.41E+10 & 0.01 & 1 & 932 & 232 \\
\hline urenium: & $013080-20-5$ & u-234 & $2.450+05$ & 4 & 1 & 1.05 & 48 \\
\hline urenium: & $018117.82-1$ & $4-235$ & $7.04 E+00$ & 02 & 1 & 0.05 & 1 \\
\hline urenium $+D^{\prime}$ & $015117-08-11+0)$ & $4.235+D$ & $7.04 E+08$ & 0.2 & 4 & & 1 \\
\hline uranium" & $007440-81.1$ & U.238 & 4.4TE+00 & 47 & 1 & 0.69 & 47 \\
\hline uranium $+D^{\circ}$ & $1007440-61.11+01$ & $U \cdot 238+D$ & $4,47 \pm+\infty$ & 1.1 & & 9.70 & 0.7 \\
\hline
\end{tabular}

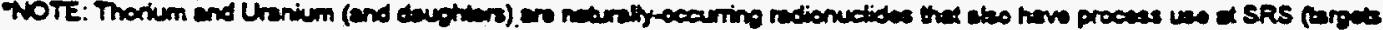

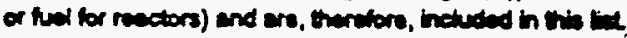

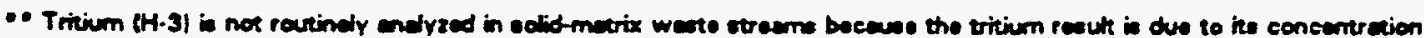
in the werer preserr in the soil a the time of endivie and not necersurity the concente rion at the time of colloction.

$\rightarrow D$ = inckuden redionctive denphtere

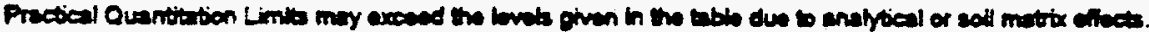

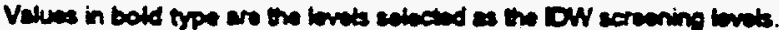




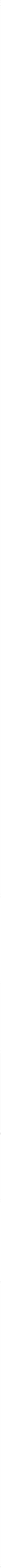




\section{SRS INVESTIGATION-DERIVED WASTE MANAGEMENT PLAN:}

WW Implementation Schedules 
This page is intentionally left blank 


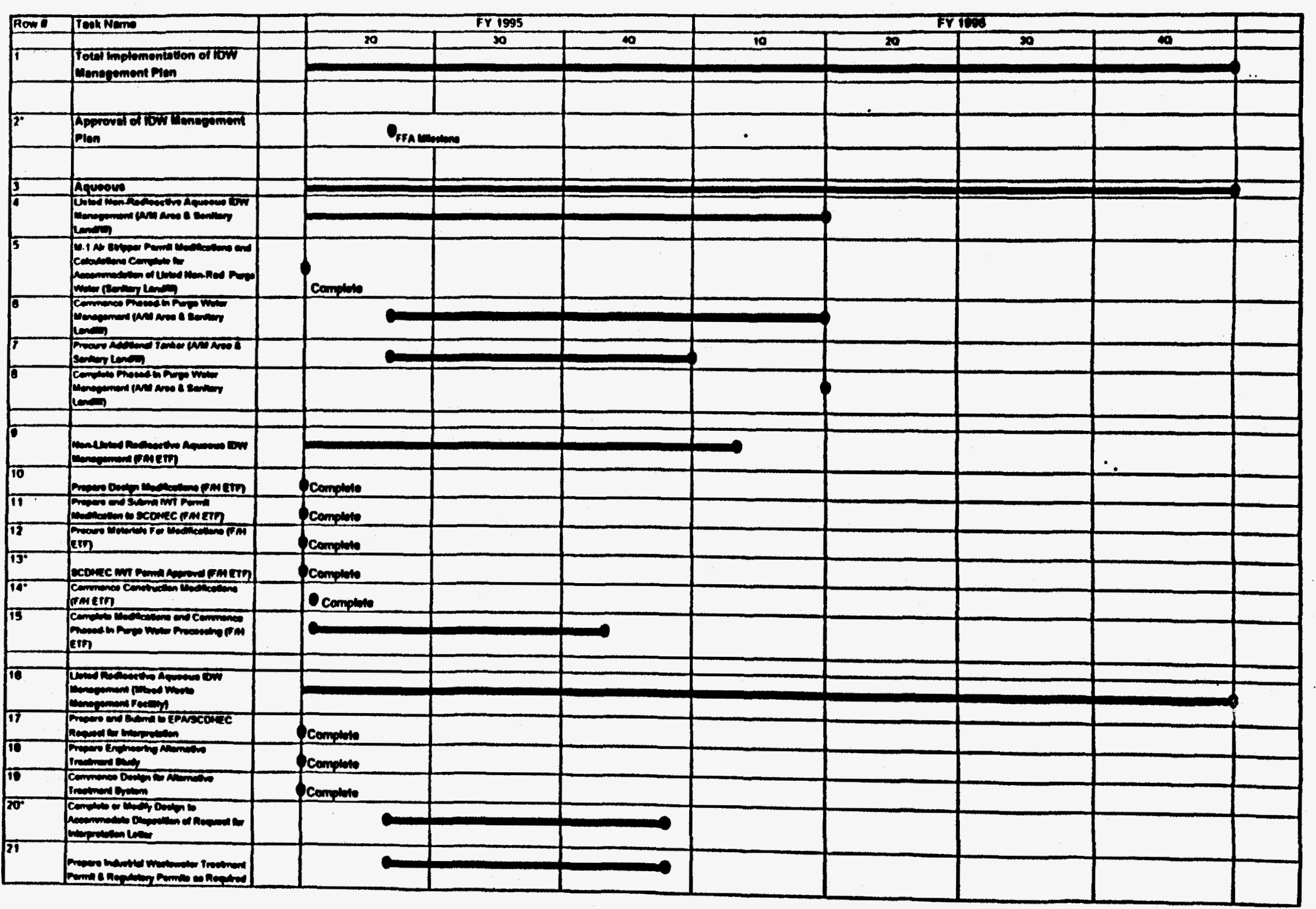


This page is intentionally left blank. 


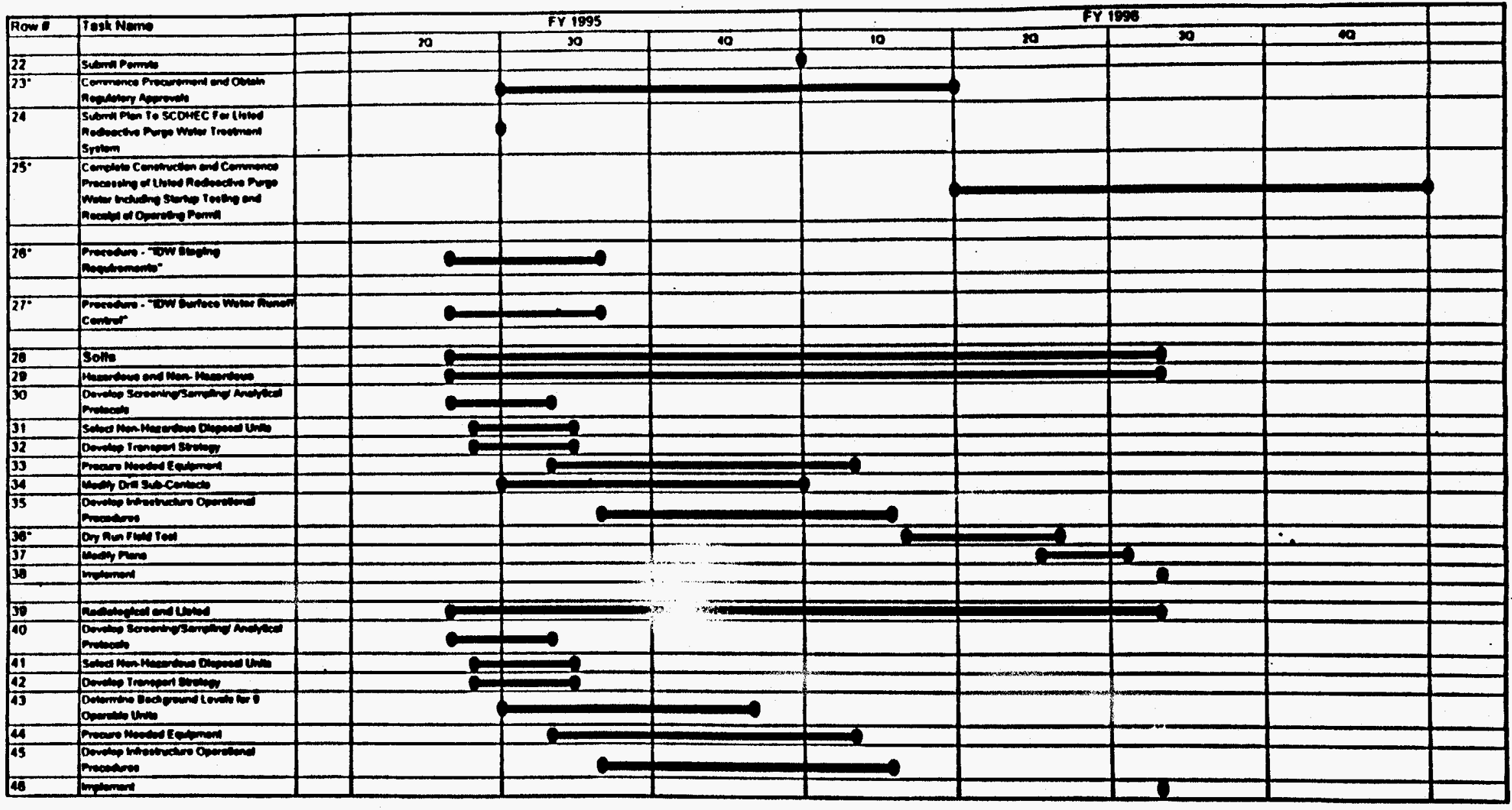

